Conference paper (Original scientific paper)

UDC: 005.61:338.012](4-191.2)(4-11)

https://doi.org/10.18045/zbefri.2019.2.427

\title{
Structural and productivity changes of Central and Eastern Europe ${ }^{* 1}$
}

\author{
Pawel Dobrzanski ${ }^{2}$, Wojciech Grabowski $i^{3}$
}

\begin{abstract}
The purpose of this paper is to analyse the structural and productivity changes of Central and Eastern European (CEE) countries. The research period covers the years following accession into the European Union, from 2004 until 2018. This study aims to answer the following question: What effects have resulted from the integration with the European Union in terms of the sphere of productivity? The analysis covers two main categories of labour productivity growth: pure labour productivity growth and structural labour productivity growth. Moreover, factors that may affect both pure and structural productivity changes are examined. The main research techniques are shift-share analysis and panel data methods. The analysis shows that all the CEE countries in the studied period improved in terms of both pure and structural productivity. The impact of pure labour productivity, however, was much smaller than that of structural labour productivity; this means that the main change in productivity level was more attributable to changes in employment between sectors than to the modernisation of technological processes. Productivity increased in all sectors, but the most significant growth occurred in service sectors, specifically in financial and insurance activities and real estate
\end{abstract}

* Received: 01-06-2019; accepted: 03-12-2019

1 The project is financed by the Ministry of Science and Higher Education in Poland under the programme "Regional Initiative of Excellence" 2019-2022 (Project number 015/RID/2018/19). The total funding amount:10 721 040,00 PLN.

We thank Professor Robert J. Barro for his discussion and comments at the 'Smart governments, regions and cities' Economics of Digital Transformation EDT Conference, Opatija, 2-4 May 2019.

2 Assistant Professor, Wroclaw University of Economics, Faculty of Economic Science, 118/120 Komandorska St, 53-345 Wroclaw, Poland. Scientific affiliation: mathematical economics. Phone: +48601594346. E-mail: pawel.dobrzanski@ue.wroc.pl.

Visiting Scholar, Department of Land Economy, University of Cambridge, 19 Silver Street, Cambridge, CB39EP Cambridge, United Kingdom.E-mail: pm703@cam.ac.uk.

${ }^{3}$ Assistant Professor, University of Lodz, Faculty of Economics and Sociology, 37/39 Rewolucji 1905 r. St, 90-214 Lodz, Poland. Scientific affiliation: models and econometric forecasts. Phone: +48536039641.E-mail: Wojciech.Grabowski@uni.lodz.pl. 
activities. Simultaneously, employment decreased in less productive sectors, such as agriculture, forestry, and fishing. Furthermore, the results of the panel data analysis confirm a significant impact of the evaluated factors on pure and structural productivity growth. Thus, aggregate productivity change in the CEE area can have a positive impact on both forms of productivity growth. Both structural and pure productivity growth are stimulated by research and development expenditures, information and communication technology (ICT) goods imports, and trade openness. Moreover, this research confirms the positive impacts of business enterprise research and development expenditure growth and an increase in the number of researchers to the workforce ratio on sector productivity, although there are substantial differences between sectors. This research can be used by government agencies in establishing industrial development policies.

Key words: structural changes, productivity, shift-share analysis, Central and Eastern European countries (CEEC), panel data analysis

JEL classification: F0, D24, G34, L33, P31

\section{Introduction}

Political and economic changes have had a significant impact on economic structure and productivity in Central and Eastern Europe (CEE). The first democratisation phase started in early 1990 and focused on building new public-administration systems. The second common stage for this region was the European Union (EU) pre-accession phase at the end of the 1990s and the beginning of the 21st century (Bouckaert et al., 2011).

The collapse of the communist system allowed CEE to transition from a centrally planned to a market economy. Central and Eastern European countries (CEEC) at this time adopted a reform package called the 'Washington Consensus'. Stabilisation and structural reforms proposed by the International Monetary Fund and World Bank included strict fiscal policy, full openness of markets to domestic and foreign trade, competitive exchange rates, price liberalisation, tax reforms, redefinition of public expenditure priorities, privatisation of state enterprises, protection of property rights, and deregulation (Williamson, 1993). These reforms were rapidly followed by the informal and formal growth of markets for consumer goods and eventually for money, industry, and services (Manning, 2004). The most important occurrence for economic structure was privatisation, which increased productivity and initiated the movement of resources from inefficient public enterprises to the nascent capitalist sector ruled by market forces.

In 2004, eight CEECs became members of the EU. These countries were Poland, the Czech Republic, Slovakia, Hungary, Slovenia, Estonia, Lithuania, and Latvia. CEECs' membership in the EU helped to stabilise the region's new political and economic systems and assisted Europeans with competing in a globalising 
economy (Carmin, 2004). EU integration influenced changes in economic structure and productivity through implementation of the four freedoms of the European Single Market, specifically free movement of goods, free movement of capital, free movement of persons, and free movement of services.

Political changes have significantly influenced the transformation of the economic structure, the economic transformation, of the CEECs. Trade liberalisation has resulted in export transformation and the restructuring of export manufacturing (Stojcic et. al., 2018; Petreski et al., 2017). In addition, CEECs have been among the largest recipients of foreign direct investment (FDI) in recent decades. FDI and absorptive capacity have been recognised as essential components for productivity convergence in CEE (Popescu, 2014). Other processes influencing the structure of CEECs' economies are both deindustrialisation and reindustrialisation (Stojcic et. al., 2019; Stojcic and Aralica, 2018; Rowthorn and Ramaswamy, 1999). The decline of traditional industries and the growth of the service sector was a popular trend in post-communist economies in the 1990s; however, the development paths differ between individual countries of the region, and in recent years the emergence of new knowledge- and technology-intensive industries has also been visible in the region. Furthermore, a significant challenge for CEECs' economies is meeting the new requirements imposed by the Fourth Industrial Revolution (so-called Industry 4.0) (Trasca et. al., 2019). Empirical studies have demonstrated that CEECs' economies do not grow based on research-driven innovation but instead depend on more advanced imported technology. Production capability is the most significant driver of productivity growth in CEE (Radosevic, 2017).

The empirical literature investigating structural and productivity changes in CEECs and Central and Eastern European regions has focused mainly on productivity convergence or the impact of individual factors on productivity (Ezcurra and Pascual, 2007; Bijsterbosch and Kolasa, 2010; Nitoi and Pochea, 2016; Skorupinska and Torrent-Sellens, 2015; Stojcic and Orlic, 2019; Radosevic, 2017; Friesenbichler and Peneder, 2016; Habib et. al., 2019; Stojcic et al., 2018). Analysis combining the subjects of productivity and structural changes of CEE has received less attention (Ezcurra and Pascual, 2007; Bah and Brada, 2009; Kutan and Yigit, 2009; Havlik, 2015; Stojcic et al., 2019; Dobrzanski and Olszewski, 2019; Dobrzanski, 2019). The research results of this paper enrich the existing literature with analysis of productivity and structural changes from accession into the EU in 2004 until the most recent available data from 2018. Furthermore, the analysis in this paper also identifies factors affecting both pure and structural productivity.

The main aim of this article is to analyse structural and productivity changes among CEECs. Three research questions are answered in this paper. First, changes in the sphere of productivity in CEECs since integration with the EU are analysed. Second, the role of structural changes, technological changes, and improvement of production processes in productivity growth are evaluated. Third, factors that 
can affect pure and structural productivity changes are examined. The research period covers the years after accession into the EU, from 2004 until 2018. The analysis concerns two main categories of labour productivity growth: pure labour productivity growth and structural labour productivity growth. To the best of our knowledge, such an analysis has not previously been undertaken for CEECs in the considered period. In addition, this study enriches the existing literature through the analysis of factors that may affect pure and structural productivity change as well as sectoral productivity change in CEECs.

This paper is organised as follows. The second section presents a literature review regarding structural changes, productivity, and economic growth. The third section describes the shift-share methodology. The fourth section presents the data chosen for analysis. The fifth section contains the research findings, and the final section concludes the research.

\section{Literature review}

One central issue in the analysis of economic growth in developing economies is structural changes, which can be defined as the reallocation of labour across sectors. According to Kuznets (1966), the transfer of labour from sectors with low productivity to other, more dynamic sectors is one of the main factors influencing overall productivity growth. Developing countries aim to reduce the productivity gaps between sectors and move away from focusing on unproductive sectors. The speed of structural transformation is the key factor that determines the competitiveness of the economy. Today, developed economies are moving towards high-productivity manufacturing and high-quality services; this triggers wage and salary improvements and has a positive impact on economic growth. At the same time, there can be a noted use of production factors in less modern and more traditional economic activities. The most developed economies are able to diversify away from agriculture and other traditional products (Yilmaz, 2015).

Sectoral labour productivity differs between countries. Duarte and Restuccia (2010) concluded that any lag in structural transformation is systematically related to the level of development of the country. Poor countries can be characterised as displaying the largest shares of hours in agriculture, while rich countries in comparison show the smallest shares. In addition, countries that start the process of structural transformation later accomplish a given amount of labour reallocation faster than countries that initiated the process earlier. Labour productivity differences between rich and poor countries are large in the areas of agriculture and services and smaller in manufacturing. As countries progress through the process of structural transformation, relative aggregate labour productivity can initially increase and then later stagnate or decline. 
McMillan and Rodrik (2011) state that developing economies can be characterised by large productivity gaps between traditional and modern sectors. Allocation may be an important engine of economic growth because, even if there is no productivity growth within sectors, the economy grows when labour and other production resources transition from less productive to more productive activities. This kind of growth-enhancing structural change can be an important contributor to overall economic growth. High-growth countries are typically those that have experienced extensive structural change.

Numerous studies have been conducted on the subject of structural changes and productivity in CEECs and Central and Eastern European regions. Productivity convergence is a frequent subject of scientific publications. Ezcurra and Pascual (2007) found an overall reduction in regional inequality over the period from 1992 to 2001 and observed simultaneous between-country convergence and withincountry divergence. Regional disparities in output per worker are linked to intrinsic differences between regions. The results of their study also confirm that the main factors that play a role in determining regional inequality in productivity have a uniform effect on output per worker across all sectors. For the period from 1995 to 2006, Bijsterbosch and Kolasa (2010) found a strong productivity convergence among CEECs at both the country level and the industry level. At the sectoral level, manufacturing has been identified as the main driver of productivity convergence, while gains in services have been less pronounced. Conversely, Nitoi and Pochea (2016) rejected the convergence hypothesis for productivity for all CEECs in most of the sectors in the period from 1995 to 2014. They found that productivity gaps in CEE decreased over this period, but significant disparities between CEECs in terms of labour productivity were still noted.

Other works have focused on the impact of individual factors on productivity. Skorupinska and Torrent-Sellens (2015) concluded that information and communication technology (ICT) capital has a significant and positive impact on productivity in CEECs. Stojcic and Orlic (2019) focused on the relation between FDI and technology spillovers and its impact on productivity in manufacturing and services. Their results suggest that FDI exerts negative intra- and interregional market-stealing effects on direct rivals and positive spillover effects on downstream firms and that these effects are larger from FDI in neighbouring regions and increase with distance. Radosevic (2017) highlights the importance of upgrading technology in improving productivity; however, the findings of his research confirm that production capability, not innovation capability, is the most significant driver of productivity growth in CEE. In addition to the impact of innovation on productivity, Friesenbichler and Peneder (2016) examined the impact of competition on productivity. Their findings confirm that competition and innovation simultaneously exert a positive effect on labour productivity in terms of either sales or value added per employee. Habib et. al. (2019) 
investigated the impact of human capital, intellectual property rights, and research and development expenditures on total factor productivity in CEECs and Brazil, Russia, India, China, and South Africa (BRICS) countries in the period from 2007 to 2015. Their results indicate that all these factors are statistically significant and have a significant impact on changes in productivity. According to the results obtained by Stojcic et al. (2018), the timing of trade liberalisation also influenced the structural transformation in new member states: Trade liberalisation increased the quality of their export manufacturing and the share of high-technology-intensive industries in their economic structures.

Studies combining the subjects of productivity and structural changes in CEE have been less frequently undertaken. Using shift-share analysis, Ezcurra and Pascual (2007) investigated the origins of regional disparities in productivity. Their research results reveal an insignificant impact of industry mix and structural components on regional dispersion in average productivity. Their analysis highlights the prominent role of the national component and the economic impact of neighbouring regions in explaining the observed disparities in sectoral productivity levels in CEE, with a declining trend over the research period. Bah and Brada (2009) studied total factor productivity growth and structural changes for new members of the EU for the years 1995, 2000, and 2005 and the basic sectors breakdown for agriculture, services, and industry. Their main conclusion was that transition economies are not a homogeneous group, as there are huge differences between them in terms of total factor productivity (TFP). In some of the new member states, productivity was not improving in industry or services, or both, making the task of catching up with the EU average an impossible one to achieve. For new member states in the analysed period, a decrease of employment in agriculture and industry was noted; meanwhile, the services sector exhibited the highest employment rate. Kutan and Yigit (2009) demonstrated that FDI and exports improve productivity but that imports exert a negative effect. Among domestic variables, human capital is the most important source of labour productivity growth in the new member states. Havlik (2015) conducted shift-share analysis of CEECs' economies for the period from 1995 to 2011. A deconstruction of value-added growth revealed that the 'within growth' effect naturally dominates the overall structural change. Haylik's (2015) analysis also revealed a distinct North-South pattern of growth: Manufacturing and trade have driven growth in the North, while there has been much less structural change in the South. Stojcic et al. (2019) investigated the determinants of structural and productive transformation in the NUTS 2 regions of CEE. Their analysis showed a decline in manufacturing employment with a simultaneous increase in the value-added share of manufacturing, which indicates productive transformation towards high-technology-intensive activities. Moreover, their study explored the role of spatial linkages in regional industrial development, and they recommend strengthening the linkages between the manufacturing core and its periphery. 
The aforementioned studies discuss the topics of structural and productivity changes in CEE from the productivity convergence perspective, the impact of individual factors on productivity, and analysis combining structural and productivity changes. The analysis performed in this paper focuses on the newest data from the period from the accession year, 2004, to 2018. The novelty of our study lies in dividing productivity growth into two sub-indexes: pure productivity growth and structural productivity growth. Furthermore, this study seeks an answer to questions concerning the impact of structural changes and technological progress on productivity after EU accession and which of these categories is the more important engine of productivity growth. Another important question concerns the factors that affect the structural and pure productivity sub-indexes.

\section{Methodology}

Shift-share analysis is a method one can use to deconstruct the change in an aggregate into two structural components. The first component involves changes in the composition of the aggregate, while the second component involves changes within the individual units that comprise the aggregate (Fagerberg, 2000). Fabricant (1942) was a pioneer in applying shift-share analysis to measure the reallocation of labour among sectors. In recent years, many reviews and extensions of shiftshare analysis have been introduced. Two of the most important extensions were introduced by Esteban-Marquillas (1972) and Arcelus (1984). In EstebanMarquillas's model, homothetic employment in sectors and regions led to the identification of an additional allocation effect. The regional share effect was deconstructed into two components, isolating a regional shift component not correlated with the industrial mix. Arcelus's model extended Esteban-Marquillas's model further. This model also used the concept of homothetic employment to represent the degree of specialization of a region. Arcelus's model, however, enabled the provision of rough estimates of the effects of local and export markets, while the original formulation by Esteban-Marquillas assumed no local market. Arcelus also emphasises that the population quotient method is a more reliable measure than employment for the analysis of market size changes. Limitations of the homothetic concept, however, have been demonstrated empirically by Loveridge and Selting (1998). Barff and Knight (1988) developed dynamic shiftshare models, which implement continuous changes in both the regional industrial mix and the size of the employment base. A dynamic model enables more accurate allocation of job change and eliminates the problems seen with static models. Nazara and Hewings (2004) emphasise the importance of the spatial effect, explaining that the location of a particular region should be included in the growth accounting. 
As is true of many research methods, the shift-share methodology has both advantages and disadvantages. Stevens and Moore (1980) emphasise that the shift-share approach is a technically simple procedure, which makes the analysis fast and reasonably accurate. Barff and Knight (1988) underline that the main advantage of shift-share analysis is that the model does not require detailed data, which, especially for less developed countries, are not easy to collect. The most frequently cited limitation of shift-share analysis is its static nature, as it is mostly applied only over a period of several years, examining the changes between the start and end dates. As stated by Sirakaya et al. (2002), however, this limitation can be overcome by calculating time-series data. Knutsen (2000) also underscores the limited predictive capabilities of this method. Moreover, the credibility of the model is questionable, and whether it explains significant changes in the industry is not certain. Therefore, some researchers are conducting additional further analysis, that is, regression analysis of the competitive effect (Andrikopoulos, et al.

Although the shift-share analysis methodology has some limitations, some of its extensions are used in the literature to analyse structural changes and their impact on economic growth. Labour productivity growth can be achieved in two ways. The first route is related to technological changes and improvement of production processes, and it is called pure labour productivity growth or within productivity growth. The second way to improve productivity is by moving labour from lowproductivity sectors to high-productivity sectors; this is called structural labour productivity growth. McMillan and Rodrik (2011) propose a basic shift-share equation that deconstructs the change in aggregate productivity into a pure and structural change effect as follows:

$$
\Delta A P_{t}=\sum_{j} \varphi_{j, t-k} \Delta S P_{t}^{j}+\sum_{j} S P_{t}^{j} \Delta \varphi_{j, t}
$$

$A P_{t}$ denotes the aggregate labour productivity, and $S P_{t}^{j}$ represents the labour productivity level of sector $j$ at time $t$. Labour productivity is the ratio of aggregate/ sectoral real output to the corresponding employment. Additionally, $\varphi_{j, t}$ represents the employment share of sector $j$ at time $t$ in overall employment. In the aggregate productivity growth equation, the first term represents the 'pure' productivity growth component, while the second term denotes the 'structural change' component. Pure labour productivity growth can be calculated as a weighted sum of productivity growth within individual sectors, with weights measured as the employment share of each sector in the context of total employment. Structural labour productivity growth is correlated with labour reallocations across different sectors. This term will be positive when employment is moving from lowproductivity sectors to high-productivity sectors; thus, structural change will increase economy-wide productivity growth. 
Moreover, to elucidate the role of macroeconomic variables in explaining structural changes and productivity changes in the CEECs, we estimate the parameters of the following panel models:

$$
\begin{aligned}
& S C_{i t}=\boldsymbol{x} \mathbf{1}_{i t} \boldsymbol{\gamma}_{1}+\varepsilon_{1 i t}, \\
& P C_{i t}=\boldsymbol{x} \boldsymbol{2}_{i t} \boldsymbol{\gamma}_{2}+\varepsilon_{2 i t},
\end{aligned}
$$

where $S C_{i t}$ denotes the structural change in the $i$-th country in period $t$, while $P C_{i t}$ denotes the productivity change in the $i$-th country in period $t$. Vector $\boldsymbol{x} \mathbf{1}_{i t}$ consists of factors affecting the structural change, while $\boldsymbol{x} \mathbf{2}_{i t}$ contains variables influencing the productivity change. The vectors of parameters $\gamma_{1}$ and $\gamma_{2}$ reflect the impact of macroeconomic variables on pure and structural labour productivity changes. $\varepsilon_{1 i t}$ and $\varepsilon_{2 i t}$ are error terms, which are assumed to have white noise properties. In order to avoid the endogeneity problem, lagged values of explanatory variables are used on the right sides of equations (2) and (3).

The choice of the appropriate panel specification depends on the results of testing. We use the traditional F-statistic in order to choose between pooled regression and the model with fixed effects (see Baltagi, 2013). The Breusch-Pagan test (see Breusch, Pagan, 1980) is used in order to choose between pooled regression and the panel model with random effects. If the fixed-effects model outperforms the pooled regression model and the random-effects model outperforms the pooled regression model, the Hausman (1978) test is used in order to choose between these two models.

After the estimation of the parameters of the models (2) and (3) is conducted and the pooled regression or the model with fixed effects is chosen as an appropriate one, serial correlation of error term is tested with the use of the Wooldridge (2002) test. If the problem of serial correlation exists, the dynamic panel model and systemic estimation with the use of Generalized Method of Moments is considered (see e.g. Blundell, Bond, 1998). Moreover, the test for cross-sectional dependence as well as the poolability test are conducted (Pesaran 2004).

Aside from models 2 and 3, which explain changes in pure and structural productivity in the period from 2004 to 2017 in the group of eight CEECs, we consider the estimation of the parameters of the models explaining productivity growth for all industries as follows:

$$
\Delta S P_{t}^{j}=\boldsymbol{x} \mathbf{3}_{i t}^{j} \boldsymbol{\gamma}_{3}^{j}+\varepsilon_{3 i t}^{j}
$$

where $S P_{t}^{j}$ is defined as in equation $1, \boldsymbol{x} \mathbf{3}_{i t}^{j}$ consists of determinants of productivity growth in the $j$-th sector, $\gamma_{3}^{j}$ contains appropriate parameters, and $\varepsilon_{3 i t}^{j}$ is the white noise error term. 


\section{Empirical data and analysis}

In the empirical investigation, we use data concerning gross value added and level of employment in the whole economies of Poland, the Czech Republic, Slovakia, Slovenia, Hungary, Latvia, Lithuania, and Estonia and the following 10 sectors: agriculture, forestry, and fishing; industry, including energy; construction; distributive trade, repairs, transport, accommodation, and food; information and communication; financial and insurance activities; real estate activities; professional, scientific research, technical, administrative, and support service activities; public administration, compulsory s.s., education, and human health; and other service activities. Gross value added and employment data used for productivity calculation has been presented in the appendices in Tables A1-A8.

On the basis of formula 1, pure productivity change and structural productivity change are calculated. Table 1 presents a deconstruction of productivity growth in the CEECs into three sub-periods: 2004 to 2008, 2009 to 2013, and 2014 to 2018. In the first sub-period, the highest labour productivity growth occurred in Slovenia, which obtained $42.94 \%$; a very high score was also obtained in Lithuania $(22.50 \%)$. It is worth underlining that all the analysed CEECs, with the sole exception of Slovakia, achieved positive results in the first four years after accession into the EU. In the second sub-period, a slight slowdown can be seen. Furthermore, Hungary recorded a decrease in labour productivity growth $(-2.99 \%)$. The decline in labour productivity growth in this country is noticeable in both pure productivity $(-0.024 \%)$ and structural productivity $(-2.96 \%)$. The decrease in productivity growth is believed to be related to the subprime mortgage crisis that took place in the United States in 2008, as this had a very strong impact on the productivity of some CEECs. Worse results in the CEECs persisted for many years after the crisis. In the third sub-period, the highest labour productivity growth was again attained in Slovenia, but the result was much lower (9.93\%). Just like Slovenia, Poland and Latvia obtained positive results in all three analysed sub-periods. 
Pawel Dobrzanski, Wojciech Grabowski $\bullet$ Structural and productivity changes...

Table 1: Labour productivity growth and pure and structural productivity in CEE countries

\begin{tabular}{|c|c|c|c|c|}
\hline Country & Mean & $\begin{array}{c}\text { Pure } \\
\text { productivity }\end{array}$ & $\begin{array}{c}\text { Structural } \\
\text { productivity }\end{array}$ & $\begin{array}{l}\text { Labour productivity } \\
\text { growth \% (component } \\
\text { due to pure and } \\
\text { structural productivity) }\end{array}$ \\
\hline \multirow{3}{*}{ Poland } & Mean (2004-2008) & 0.165 & 2.862 & 3.027 \\
\hline & Mean (2009-2013) & 0.012 & 4.156 & 4.168 \\
\hline & Mean (2014-2018) & 0.011 & 3.261 & 3.272 \\
\hline \multirow{3}{*}{$\begin{array}{l}\text { The Czech } \\
\text { Republic }\end{array}$} & Mean (2004-2008) & 0.166 & 10.209 & 10.374 \\
\hline & Mean (2009-2013) & -0.019 & 1.651 & 1.631 \\
\hline & Mean (2014-2018) & 0.023 & -1.457 & -1.434 \\
\hline \multirow{3}{*}{ Estonia } & Mean (2004-2008) & 0.178 & 8.169 & 8.347 \\
\hline & Mean (2009-2013) & 0.023 & 12.508 & 12.532 \\
\hline & Mean (2014-2018) & 0.025 & -6.970 & -6.945 \\
\hline \multirow{3}{*}{ Lithuania } & Mean (2004-2008) & 0.201 & 22.303 & 22.503 \\
\hline & Mean (2009-2013) & 0.026 & 17.746 & 17.772 \\
\hline & Mean (2014-2018) & 0.019 & -1.395 & -1.377 \\
\hline \multirow{3}{*}{ Latvia } & Mean (2004-2008) & 0.220 & 8.235 & 8.456 \\
\hline & Mean (2009-2013) & 0.004 & 3.906 & 3.910 \\
\hline & Mean (2014-2018) & 0.031 & 3.825 & 3.855 \\
\hline \multirow{3}{*}{ Slovakia } & Mean (2004-2008) & 0.218 & -0.437 & -0.219 \\
\hline & Mean (2009-2013) & 0.010 & 12.032 & 12.042 \\
\hline & Mean (2014-2018) & 0.002 & 2.715 & 2.717 \\
\hline \multirow{3}{*}{ Slovenia } & Mean (2004-2008) & 0.116 & 42.822 & 42.939 \\
\hline & Mean (2009-2013) & -0.014 & 14.863 & 14.849 \\
\hline & Mean (2014-2018) & 0.014 & 9.920 & 9.934 \\
\hline \multirow{3}{*}{ Hungary } & Mean (2004-2008) & 0.138 & 13.698 & 13.837 \\
\hline & Mean (2009-2013) & -0.024 & -2.963 & -2.987 \\
\hline & Mean (2014-2018) & 0.007 & -1.746 & -1.739 \\
\hline \multirow{3}{*}{ CEE average } & Mean (2004-2008) & 0.175 & 13.483 & 13.658 \\
\hline & Mean (2009-2013) & 0.002 & 7.987 & 7.990 \\
\hline & Mean (2014-2018) & 0.016 & 1.019 & 1.036 \\
\hline
\end{tabular}

Source: Authors' own study based on the OECD database

In Table 2, productivity by country is presented. Descriptive statistics illustrate that, in the studied period, all the CEECs improved in terms of both pure and structural productivity. The impact of pure labour productivity, however, was ultimately much smaller. This means that the main change in the productivity level was due to changes in employment among sectors rather than the modernisation of technological processes. 
Pawel Dobrzanski, Wojciech Grabowski $\bullet$ Structural and productivity changes...

Table 2: Productivity by country

\begin{tabular}{|c|c|c|c|c|c|c|c|c|c|}
\hline & 2004 & 2005 & 2006 & 2007 & 2008 & 2009 & 2010 & 2011 & 2012 \\
\hline \multicolumn{10}{|l|}{ POLAND } \\
\hline Pure productivity & 0.21 & 0.15 & 0.08 & 0.20 & 0.18 & -0.16 & 0.11 & 0.11 & -0.05 \\
\hline Structural productivity & 5.75 & -8.56 & -4.94 & 11.38 & 10.68 & 21.64 & 13.31 & -0.75 & -10.64 \\
\hline Overall productivity & 5.96 & -8.41 & -4.87 & 11.59 & 10.86 & 21.48 & 13.42 & -0.65 & -10.69 \\
\hline \multicolumn{10}{|l|}{ CZECH REPUBLIC } \\
\hline Pure productivity & 0.19 & 0.12 & 0.13 & 0.18 & 0.21 & -0.12 & 0.02 & 0.10 & -0.10 \\
\hline Structural productivity & 2.61 & 12.51 & 14.20 & 5.96 & 15.76 & 15.21 & 1.20 & -26.62 & 16.26 \\
\hline Overall productivity & 2.80 & 12.63 & 14.33 & 6.14 & 15.97 & 15.09 & 1.22 & -26.52 & 16.16 \\
\hline \multicolumn{10}{|l|}{ ESTONIA } \\
\hline Pure productivity & 0.22 & 0.13 & 0.13 & 0.31 & 0.10 & -0.12 & 0.06 & 0.12 & -0.03 \\
\hline Structural productivity & -3.50 & -9.10 & 1.11 & 22.07 & 30.27 & 10.06 & 17.26 & 15.22 & 6.52 \\
\hline Overall productivity & -3.28 & -8.98 & 1.24 & 22.38 & 30.37 & 9.94 & 17.33 & 15.33 & 6.49 \\
\hline \multicolumn{10}{|l|}{ LITHUANIA } \\
\hline Pure productivity & 0.22 & 0.14 & 0.15 & 0.27 & 0.22 & -0.14 & 0.05 & 0.18 & -0.02 \\
\hline Structural productivity & -5.04 & 49.10 & 10.24 & -7.29 & 64.50 & 24.02 & 33.11 & -1.12 & 10.23 \\
\hline Overall productivity & -4.82 & 49.24 & 10.39 & -7.02 & 64.73 & 23.88 & 33.16 & -0.95 & 10.21 \\
\hline \multicolumn{10}{|l|}{ LATVIA } \\
\hline Pure productivity & 0.23 & 0.14 & 0.17 & 0.39 & 0.18 & -0.13 & -0.02 & 0.17 & -0.04 \\
\hline Structural productivity & 8.32 & -4.47 & -1.96 & 25.10 & 14.18 & 5.37 & -3.18 & 6.15 & 4.04 \\
\hline Overall productivity & 8.55 & -4.32 & -1.79 & 25.49 & 14.36 & 5.24 & -3.21 & 6.32 & 4.01 \\
\hline \multicolumn{10}{|l|}{ SLOVAKIA } \\
\hline Pure productivity & 0.26 & 0.12 & 0.16 & 0.32 & 0.23 & -0.05 & 0.02 & 0.07 & -0.04 \\
\hline Structural productivity & -6.63 & 15.54 & 1.04 & 21.90 & -34.05 & 13.87 & 27.98 & 25.63 & 3.66 \\
\hline Overall productivity & -6.37 & 15.66 & 1.20 & 22.22 & -33.82 & 13.82 & 28.01 & 25.70 & 3.62 \\
\hline \multicolumn{10}{|l|}{ SLOVENIA } \\
\hline Pure productivity & 0.17 & 0.06 & 0.06 & 0.17 & 0.12 & -0.09 & -0.02 & 0.10 & -0.09 \\
\hline Structural productivity & 3.26 & 37.92 & 58.92 & 50.96 & 63.05 & 51.76 & 18.37 & -8.70 & -1.80 \\
\hline Overall productivity & 3.43 & 37.98 & 58.98 & 51.14 & 63.16 & 51.67 & 18.34 & -8.60 & -1.89 \\
\hline \multicolumn{10}{|l|}{ HUNGARY } \\
\hline Pure productivity & 0.24 & 0.09 & 0.02 & 0.20 & 0.15 & -0.17 & 0.01 & 0.09 & -0.10 \\
\hline Structural productivity & 13.55 & 7.37 & 13.28 & 5.20 & 29.09 & -4.90 & -7.06 & -0.80 & -11.39 \\
\hline Overall productivity & 13.79 & 7.46 & 13.30 & 5.40 & 29.24 & -5.08 & -7.05 & -0.71 & -11.49 \\
\hline
\end{tabular}


Pawel Dobrzanski, Wojciech Grabowski $\bullet$ Structural and productivity changes...

Zb. rad. Ekon. fak. Rij. • $2019 \cdot$ vol. $37 \cdot$ no. $2 \cdot 427-471$

\begin{tabular}{|c|c|c|c|c|c|c|c|c|}
\hline & 2013 & 2014 & 2015 & 2016 & 2017 & 2018 & $\begin{array}{c}\text { Sum } \\
(2004-2018)\end{array}$ & Mean \\
\hline \multicolumn{9}{|l|}{ POLAND } \\
\hline Pure productivity & 0.06 & 0.01 & -0.15 & -0.02 & 0.11 & 0.10 & 0.94 & 0.06 \\
\hline Structural productivity & -2.78 & 19.45 & 8.79 & -9.90 & -13.41 & 11.38 & 51.40 & 3.43 \\
\hline Overall productivity & -2.72 & 19.46 & 8.64 & -9.92 & -13.30 & 11.48 & 52.33 & 3.49 \\
\hline \multicolumn{9}{|l|}{ CZECH REPUBLIC } \\
\hline Pure productivity & 0.00 & 0.00 & -0.11 & 0.03 & 0.09 & 0.12 & 0.84 & 0.06 \\
\hline Structural productivity & 2.20 & 1.32 & -5.70 & 0.04 & -1.81 & -1.13 & 52.01 & 3.47 \\
\hline Overall productivity & 2.20 & 1.32 & -5.82 & 0.06 & -1.72 & -1.01 & 52.86 & 3.52 \\
\hline \multicolumn{9}{|l|}{ ESTONIA } \\
\hline Pure productivity & 0.08 & 0.05 & -0.17 & 0.04 & 0.09 & 0.12 & 1.13 & 0.08 \\
\hline Structural productivity & 13.48 & -27.41 & -6.83 & 37.23 & -27.98 & -9.86 & 68.53 & 4.57 \\
\hline Overall productivity & 13.56 & -27.37 & -7.00 & 37.27 & -27.89 & -9.73 & 69.67 & 4.64 \\
\hline \multicolumn{9}{|l|}{ LITHUANIA } \\
\hline Pure productivity & 0.07 & 0.03 & -0.16 & 0.01 & 0.11 & 0.11 & 1.23 & 0.08 \\
\hline Structural productivity & 22.49 & -11.03 & -4.95 & -2.96 & 5.32 & 6.65 & 193.27 & 12.88 \\
\hline Overall productivity & 22.56 & -11.01 & -5.10 & -2.95 & 5.43 & 6.76 & 194.49 & 12.97 \\
\hline \multicolumn{9}{|l|}{ LATVIA } \\
\hline Pure productivity & 0.04 & 0.04 & -0.15 & 0.02 & 0.12 & 0.12 & 1.27 & 0.08 \\
\hline Structural productivity & 7.15 & 10.07 & 1.67 & 4.68 & 1.06 & 1.65 & 79.83 & 5.32 \\
\hline Overall productivity & 7.19 & 10.12 & 1.52 & 4.69 & 1.18 & 1.77 & 81.10 & 5.41 \\
\hline \multicolumn{9}{|l|}{ SLOVAKIA } \\
\hline Pure productivity & 0.05 & 0.03 & -0.15 & 0.00 & 0.04 & 0.09 & 1.15 & 0.08 \\
\hline Structural productivity & -10.98 & -7.85 & -0.37 & 23.21 & 11.33 & -12.75 & 71.55 & 4.77 \\
\hline Overall productivity & -10.93 & -7.82 & -0.52 & 23.21 & 11.37 & -12.67 & 72.70 & 4.85 \\
\hline \multicolumn{9}{|l|}{ SLOVENIA } \\
\hline Pure productivity & 0.04 & 0.05 & -0.15 & 0.02 & 0.05 & 0.10 & 0.58 & 0.04 \\
\hline Structural productivity & 14.69 & 3.08 & -1.25 & 11.46 & 22.04 & 14.27 & 338.03 & 22.54 \\
\hline Overall productivity & 14.73 & 3.12 & -1.40 & 11.48 & 22.10 & 14.36 & 338.61 & 22.57 \\
\hline \multicolumn{9}{|l|}{ HUNGARY } \\
\hline Pure productivity & 0.06 & -0.01 & -0.15 & 0.00 & 0.09 & 0.09 & 0.61 & 0.04 \\
\hline Structural productivity & 9.33 & -5.83 & 0.02 & -1.07 & -5.69 & 3.84 & 44.95 & 3.00 \\
\hline Overall productivity & 9.39 & -5.84 & -0.13 & -1.06 & -5.59 & 3.93 & 45.56 & 3.04 \\
\hline
\end{tabular}

Source: Authors' own study based on the OECD database 
Results in Table 2 indicate that there are differences between the countries in terms of pure and structural productivity changes in the period from 2004 to 2018 . Considering the entire analysed period (2004-2018), Slovenia experienced rapid overall labour productivity growth of almost $22.57 \%$ per annum, most of which was accounted for by structural change. Hungary attained the lowest overall productivity growth. Separately, the fastest pure productivity growth is observed in the Baltic countries and Slovakia, while the slowest pace of growth can be noticed in such countries as Hungary and Slovenia. Conversely, structural productivity improved at the fastest pace in Slovenia and at the slowest pace in Hungary, Poland, and the Czech Republic. One very positive finding is that, despite large fluctuations in several countries, an increase in productivity can be observed in all the CEECs analysed after their accession into the EU.

Table 3 presents the labour productivity gaps between different sectors. In all the CEECs, the highest productivity can be observed in sector 7 (real estate activities (ISIC rev4)); very high productivity can also be noted in sectors 5 (information and communication (ISIC rev4)) and 6 (financial and insurance activities (ISIC rev4)), while the lowest productivity is found in sector 1 (agriculture, hunting and forestry, and fishing (ISIC rev4), AGRI). Across all the CEECs, the productivity in sector 7 is almost 17 times higher than that in sector 1 . It is worth underlining that productivity in all sectors increased during the analysed period. In almost all the analysed CEECs, the highest change can be noted in sector 1 (AGRI); this is a very agreeable phenomenon because it suggests that the productivity in the sector with the least productivity increased. Analysing the above statistics, it can be concluded that all employees should work in sectors 5, 6, and 7. Of course, such a situation cannot take place; however, it can be more meaningful to compare productivity levels across sectors with similar levels of potential to absorb labour. In all the analysed periods, labour productivity in agriculture was usually 3 times less than labour productivity in all other sectors with similar potential to absorb labour. 


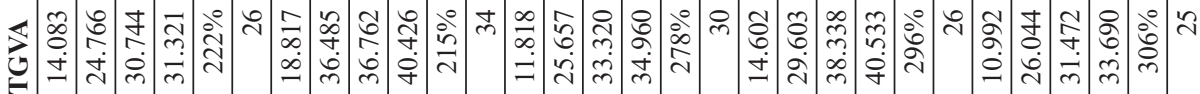

๘)

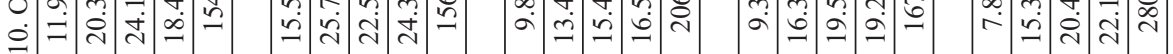

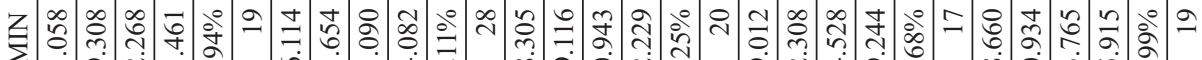

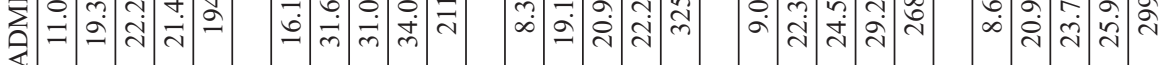

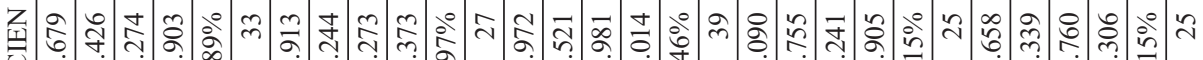

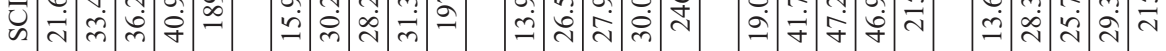
$\infty$

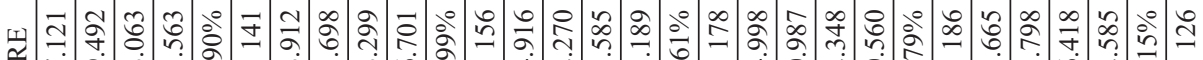

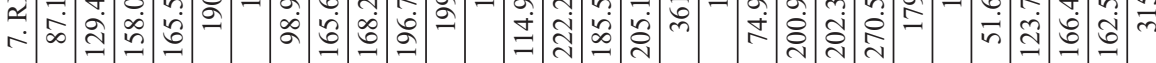

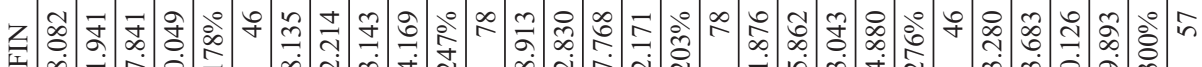

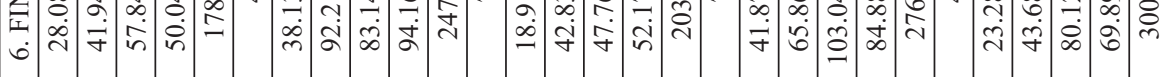
壵

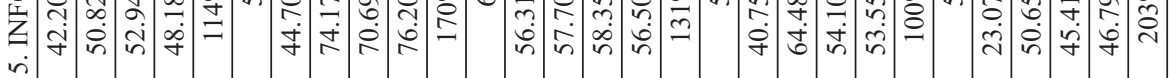

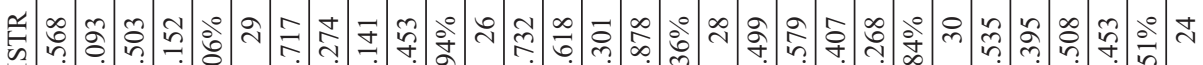

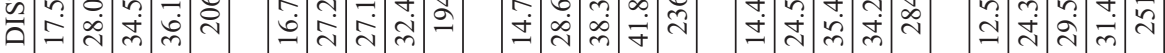

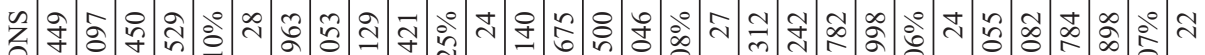

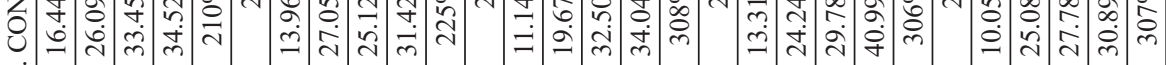

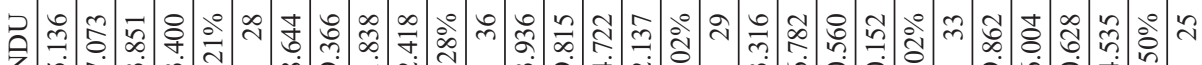

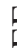

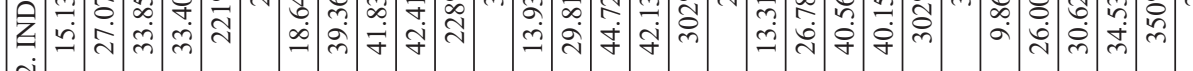

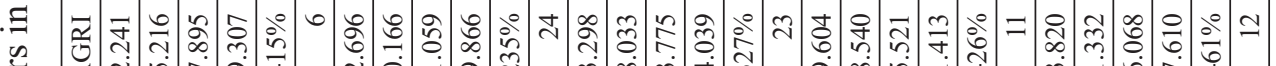

늘

음

ฉ

\begin{tabular}{|c|c|c|c|c|c|c|c|c|c|c|c|c|c|c|c|c|c|}
\hline & & & & & & & & & & & & & & & & & \\
\hline 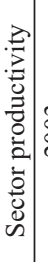 & & 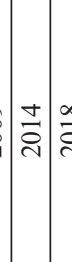 & 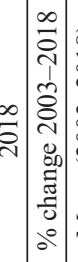 & 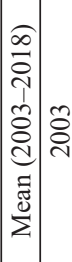 & 言 & 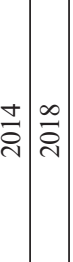 & 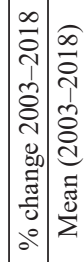 & 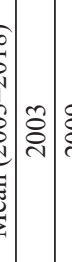 & ¿্خे| & 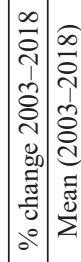 & 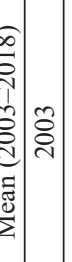 & ڤे & 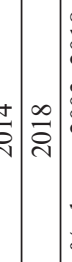 & 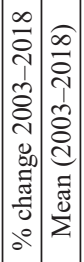 & 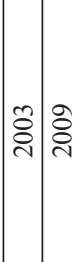 & S. & 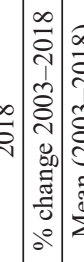 \\
\hline $\begin{array}{l}E \\
\vdots \\
\vdots \\
\end{array}$ & & $\begin{array}{l}\overrightarrow{0} \\
\frac{\vec{t}}{0} \\
2\end{array}$ & & & & $\begin{array}{l}\text { ज्ञ } \\
\text { N }\end{array}$ & & & 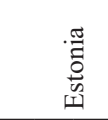 & & & & 嚞 & & & $\widetilde{\Xi}$ & \\
\hline
\end{tabular}


Pawel Dobrzanski, Wojciech Grabowski $\bullet$ Structural and productivity changes... Zb. rad. Ekon. fak. Rij. • $2019 \cdot$ vol. $37 \cdot$ no. $2 \cdot 427-471$

용

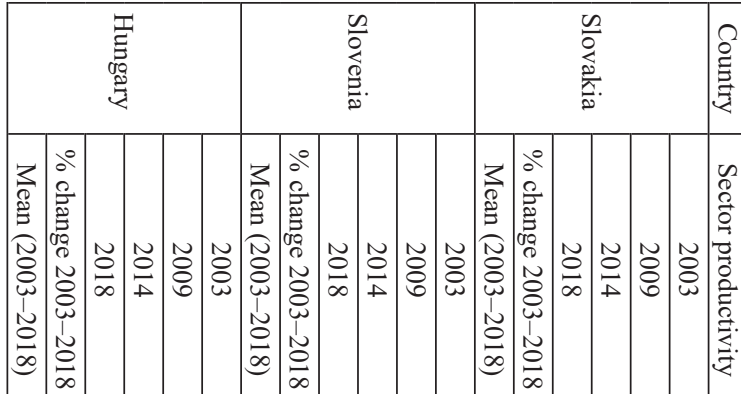

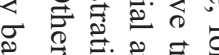

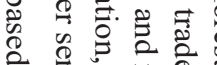

ㄴ. जै

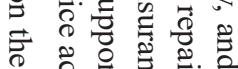

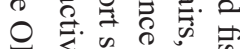

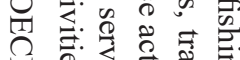

$\Theta$ ๙

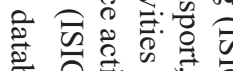

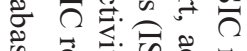

这零

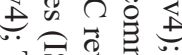

$\exists \bar{\Omega}$

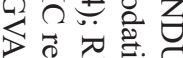

元苇.

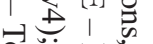

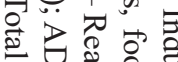

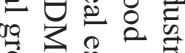

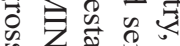

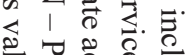

ฮั

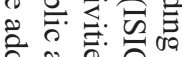

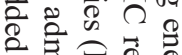

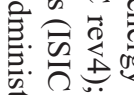

$\approx \tilde{Q}$

응

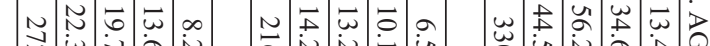

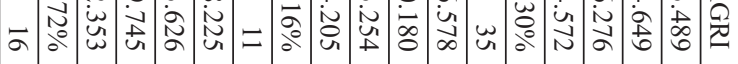

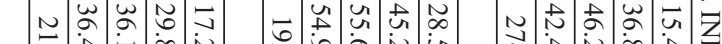

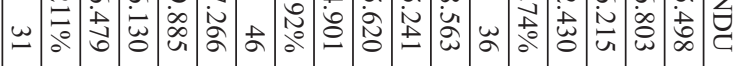

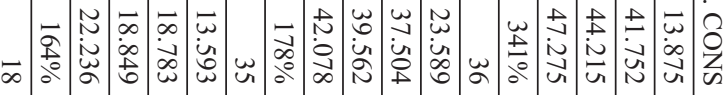

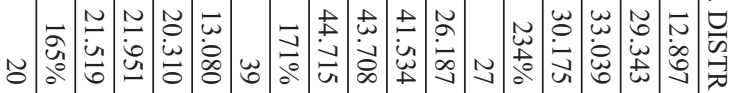

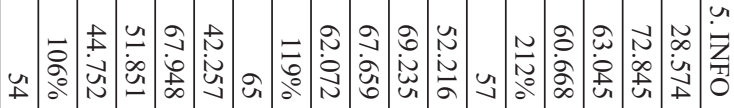

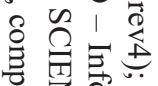

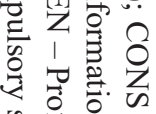

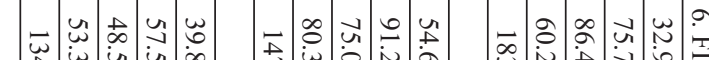

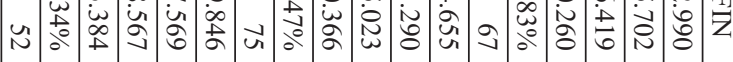

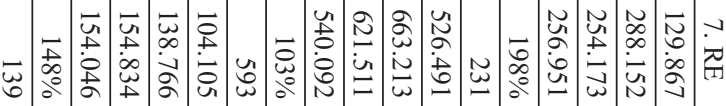

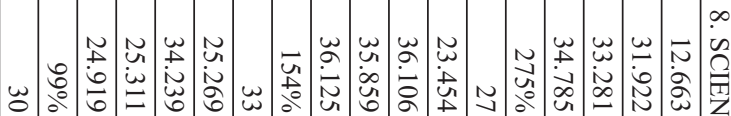

is

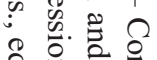

82

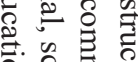

ㅎ. ㄴ.

常.

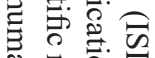

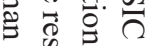

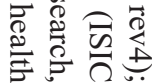

แ N N N

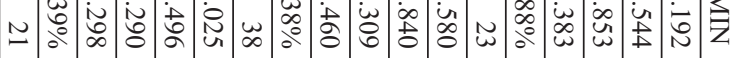

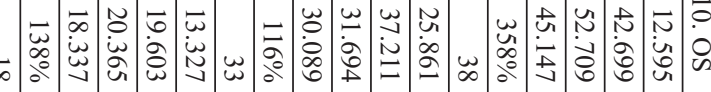

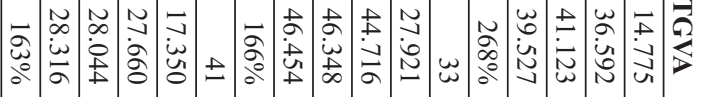


Aside from collecting data on productivity, we also gathered data concerning factors that may affect pure and structural productivity change as well as sectoral productivity change. Table 4 consists of definitions of variables with justifications concerning the impact of these categories on pure and structural productivity change as well as on sectoral productivity change.

Table 4: Variables that are considered as determinants of pure and structural productivity change as well as determinants of sectoral productivity change

\begin{tabular}{|c|c|c|}
\hline \multicolumn{3}{|c|}{ Variables observable at a country level explaining structural and pure productivity change } \\
\hline Variable & Definition & Expected impact of variable on productivity change \\
\hline$R D \_$change & $\begin{array}{l}\text { Change in the ratio of } \\
\text { Research and development } \\
\text { expenditure to GDP }\end{array}$ & $\begin{array}{l}\text { The relationship between innovativeness and productivity } \\
\text { has been broadly studied within the CDM model framework } \\
\text { (see e.g., Crepon et al., 1998; Szczygielski \& Grabowski } \\
2014 \text {; Fazlioglu et al., 2019). According to the conceptual } \\
\text { model, R\&D efforts positively affected innovativeness, which } \\
\text { has a positive impact on productivity. It is expected that } \\
\text { there is a positive correlation between investing in R\&D and } \\
\text { productivity growth when enterprises from the same industry } \\
\text { are considered. Therefore, the positive estimate of a parameter } \\
\text { for this variable in the equation explaining pure productivity } \\
\text { change is expected. }\end{array}$ \\
\hline ICT_IMPORT & $\begin{array}{l}\text { Change in the ratio of ICT } \\
\text { goods imports to total goods } \\
\text { imports }\end{array}$ & $\begin{array}{l}\text { Since CEE countries are not technology leaders, they must } \\
\text { import ICT goods in order to improve production processes. } \\
\text { A higher level of imports of ICT goods means that the use of } \\
\text { ICT is more frequent. A positive relationship between using } \\
\text { ICT and productivity in the group of enterprises from the same } \\
\text { industry was identified among others by Arendt and Grabowski } \\
\text { (2017), so the positive relationship between this variable and } \\
\text { pure productivity change is expected. However, the use of ICT } \\
\text { is industry-dependent, so this variable should have a positive } \\
\text { impact on structural productivity change. }\end{array}$ \\
\hline TO_CHANGE & $\begin{array}{l}\text { Change in the level of trade } \\
\text { openness (export }+ \text { import to } \\
\text { GDP ratio) }\end{array}$ & $\begin{array}{l}\text { Higher level of trade openness informs about higher propensity } \\
\text { to import new products and higher level of internationalization } \\
\text { of domestic enterprises. Internationalization seems to have a } \\
\text { positive impact on productivity (Sun et al., 2019). Therefore, a } \\
\text { positive estimate of the parameter for this variable is expected } \\
\text { in equations explaining pure productivity growth as well as } \\
\text { structural productivity growth. }\end{array}$ \\
\hline \multicolumn{3}{|c|}{ Variables observable at a sectoral level explaining sectoral productivity change } \\
\hline$\triangle B E R D$ & $\begin{array}{l}\text { Change in business } \\
\text { enterprise } R \& D \text { expenditure } \\
\text { per worker in constant prices }\end{array}$ & \multirow[t]{2}{*}{$\begin{array}{l}\text { Higher values of these variables inform about higher levels } \\
\text { of innovativeness of a sector. Therefore, positive estimates of } \\
\text { parameters are expected. }\end{array}$} \\
\hline RES & $\begin{array}{l}\text { Ratio of number of } \\
\text { researchers to the number of } \\
\text { all workers within sector }\end{array}$ & \\
\hline
\end{tabular}

Source: Authors' own study based on literature review and the OECD database 
Table 5 consists of descriptive statistics for potential explanatory variables (in equations 2 and 3 ).

Table 5: Descriptive statistics for potential explanatory variables

\begin{tabular}{|l|c|c|c|c|}
\hline \multicolumn{1}{|c|}{ Variable } & Mean & Standard deviation & Minimum & Maximum \\
\hline$R D$ & 0.027 & 0.149 & -0.400 & 0.725 \\
\hline ICT_IMPORT & 9.86 & 4.67 & 3.28 & 21.20 \\
\hline TO_CHANGE & 3.02 & 9.42 & -26.22 & 27.15 \\
\hline
\end{tabular}

Source: Authors' own study based on the OECD database

The results of testing the order of integration for variables on the basis of the Hadri test (Hadri, 2000) are presented in Table 6.

Table 6: Results of testing the order of integration on the basis of the Hadri test

\begin{tabular}{|l|c|c|l|}
\hline \multicolumn{1}{|c|}{ Variable } & Statistic & $\mathrm{p}$-value & Decision \\
\hline$S C$ & -1.74 & 0.959 & Stationary \\
\hline$P C$ & -2.12 & 0.983 & Stationary \\
\hline$R D$ & 1.15 & 0.126 & Stationary \\
\hline$I C T$ IMPORT & 0.06 & 0.477 & Stationary \\
\hline$T O \_C H A N G E$ & -1.36 & 0.913 & Stationary \\
\hline
\end{tabular}

Source: Authors' own study based on the OECD database

The results of testing the order of integration for the variables used in model 4 for all sectors are presented in Table 7.

Table 7: Results of testing the order of integration for sectoral variables for sectors on the basis of the Hadri test

\begin{tabular}{|l|c|c|c|c|c|c|}
\hline \multirow{2}{*}{ Activity } & \multicolumn{2}{|c|}{$\Delta S P$} & \multicolumn{2}{c|}{$\triangle B E R D$} & \multicolumn{2}{c|}{ RES } \\
\cline { 2 - 7 } & $\mathrm{p}$-value & Decision & p-value & Decision & p-value & Decision \\
\hline Agriculture, forestry, and fishing & 0.873 & $\mathrm{I}(0)$ & 0.653 & $\mathrm{I}(0)$ & 0.765 & $\mathrm{I}(0)$ \\
\hline Industry, including energy & 0.753 & $\mathrm{I}(0)$ & 0.783 & $\mathrm{I}(0)$ & 0.673 & $\mathrm{I}(0)$ \\
\hline Construction & 0.912 & $\mathrm{I}(0)$ & 0.821 & $\mathrm{I}(0)$ & 0.540 & $\mathrm{I}(0)$ \\
\hline $\begin{array}{l}\text { Distributive trade, repairs, transport, } \\
\text { accommodation, food services }\end{array}$ & 0.723 & $\mathrm{I}(0)$ & 0.562 & $\mathrm{I}(0)$ & 0.611 & $\mathrm{I}(0)$ \\
\hline Information and communication & 0.651 & $\mathrm{I}(0)$ & 0.712 & $\mathrm{I}(0)$ & 0.529 & $\mathrm{I}(0)$ \\
\hline Financial and insurance activities & 0.412 & $\mathrm{I}(0)$ & 0.612 & $\mathrm{I}(0)$ & 0.487 & $\mathrm{I}(0)$ \\
\hline Real estate activities & 0.712 & $\mathrm{I}(0)$ & 0.632 & $\mathrm{I}(0)$ & 0.791 & $\mathrm{I}(0)$ \\
\hline $\begin{array}{l}\text { Professional, scientific research, } \\
\text { technical; administrative, support } \\
\text { service activities }\end{array}$ & 0.932 & $\mathrm{I}(0)$ & 0.689 & $\mathrm{I}(0)$ & 0.673 & $\mathrm{I}(0)$ \\
\hline $\begin{array}{l}\text { Public administration, compulsory s.s., } \\
\text { education, human health }\end{array}$ & 0.721 & $\mathrm{I}(0)$ & 0.590 & $\mathrm{I}(0)$ & 0.873 & $\mathrm{I}(0)$ \\
\hline Other service activities & 0.652 & $\mathrm{I}(0)$ & 0.629 & $\mathrm{I}(0)$ & 0.721 & $\mathrm{I}(0)$ \\
\hline
\end{tabular}

Source: Authors' own study based on OECD Data Base 
The results in Tables 6 and 7 indicate that all the variables are stationary and that the problem of spurious regression does not exist.

Due to the stationarity of all the variables, standard panel data methods are applied.

Table 8 consists of the results of testing for the presence of fixed and random effects in equations 2 and 3.

Table 8: Results of testing for the presence of fixed and random effects in panel regression

\begin{tabular}{|c|c|c|c|c|c|c|}
\hline & \multicolumn{3}{|c|}{ Equation explaining SC } & \multicolumn{3}{|c|}{ Equation explaining PC } \\
\hline & Statistic & $\mathrm{p}$-value & Decision & Statistic & p-value & Decision \\
\hline $\begin{array}{l}\text { Testing for presence of } \\
\text { fixed effects }\end{array}$ & 1.46 & 0.20 & \multirow{2}{*}{$\begin{array}{l}\text { Random } \\
\text { effects }\end{array}$} & 0.44 & 0.88 & \multirow{2}{*}{$\begin{array}{c}\text { Random } \\
\text { effects }\end{array}$} \\
\hline $\begin{array}{l}\text { Testing for presence of } \\
\text { random effects }\end{array}$ & 4.04 & 0.04 & & 2.78 & 0.09 & \\
\hline
\end{tabular}

Source: Authors' own study based on the OECD database

The results of this testing indicate that at the 0.1 level of significance the random effects model is the best option in both cases. Table 9 presents the results of the estimation of the parameters of both models, with the results of testing significance. Since all variables are stationary (see Table 6), cointegration test is not conducted.

Table 9: Results of the estimation of the parameters of the random effects model explaining pure and structural productivity change ${ }^{4}$

\begin{tabular}{|l|r|r|r|r|}
\hline \multirow{2}{*}{ Explanatory variable } & \multicolumn{2}{|c|}{ Equation explaining SC } & \multicolumn{2}{c|}{ Equation explaining PC } \\
\cline { 2 - 5 } & \multicolumn{1}{c|}{ Estimate } & Standard error & Estimate & \multicolumn{1}{c|}{ Standard error } \\
\hline$R D$ & $0.227^{* * *}$ & 0.084 & $0.043^{*}$ & 0.026 \\
\hline$I C T \_I M P O R T$ & $2.24^{* *}$ & 1.09 & $0.029^{* * *}$ & 0.011 \\
\hline TO_CHANGE & $0.012^{* * *}$ & 0.004 & $0.008^{* * *}$ & 0.001 \\
\hline
\end{tabular}

Note: $* * *$ and $* * *$ denote significance at the $0.1,0.05$, and 0.01 levels of significance, respectively.

Source: Authors' own study based on OECD database

The results of the estimation indicate that the factors shaping pure and structural productivity growth are substantially effective.

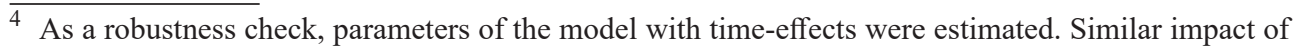
R\&D expenditure, ICT import and trade openness on productivity growth was identified.
} 
Conversely, the ICT goods imports to total goods imports ratio exhibited positive and statistically significant impacts on pure and structural productivity change. Since the purchasing of information and communication technology results in higher capabilities within enterprises, this result is not surprising. An improvement in trade openness may be associated with an increase in high-technology imports, which positively affects the productivity level. Therefore, the positive and significant impact of the variable TO_CHANGE is also in line with expectations.

In order to test validity of assumptions, the poolability test as well as the test for cross-sectional dependence is conducted. Results of testing are presented in the table 10 .

Table 10: Results of testing poolability and cross-sectional dependence

\begin{tabular}{|l|c|c|c|c|}
\hline \multirow{2}{*}{ Testing } & \multicolumn{2}{|c|}{ Equation explaining SC } & \multicolumn{2}{c|}{ Equation explaining PC } \\
\cline { 2 - 5 } & Statistic & p-value & Statistic & p-value \\
\hline Poolability & 1.181 & 0.310 & 0.725 & 0.817 \\
\hline $\begin{array}{l}\text { Cross-sectional } \\
\text { dependence }\end{array}$ & 0.920 & 0.359 & 1.525 & 0.217 \\
\hline
\end{tabular}

Source: Authors' own study based on the OECD database

Testing results indicate that there is no cross-sectional dependence problem. Moreover, the results of testing poolability indicate that parameters are stable across countries.

Due to the stationarity of the dependent and explanatory variables in equation 4, standard panel data methods are applied. Table 11 consists of the results of testing for the presence of fixed and random effects using equation 4 for all sectors.

Table 11: Results of testing for the presence of fixed and random effects in panel regressions for all sectors

\begin{tabular}{|l|c|c|c|}
\hline \multicolumn{1}{|c|}{ Activity } & $\begin{array}{c}\text { Testing for } \\
\text { presence of fixed } \\
\text { effects (p-value) }\end{array}$ & $\begin{array}{c}\text { Testing for } \\
\text { presence of random } \\
\text { effects (p-value) }\end{array}$ & Decision \\
\hline Agriculture, forestry, and fishing & 0.46 & 1.00 & Pooled regression \\
\hline Industry, including energy & 0.95 & 0.97 & Pooled regression \\
\hline Construction & 0.91 & 0.99 & Pooled regression \\
\hline $\begin{array}{l}\text { Distributive trade, repairs, transport, } \\
\text { accommodations, food services }\end{array}$ & 0.73 & 1.00 & Pooled regression \\
\hline Information and communication & 0.77 & 0.96 & Pooled regression \\
\hline Financial and insurance activities & 0.75 & 0.98 & Pooled regression \\
\hline
\end{tabular}


Pawel Dobrzanski, Wojciech Grabowski • Structural and productivity changes...

\begin{tabular}{|l|c|c|c|}
\hline \multicolumn{1}{|c|}{ Activity } & $\begin{array}{c}\text { Testing for } \\
\text { presence of fixed } \\
\text { effects (p-value) }\end{array}$ & $\begin{array}{c}\text { Testing for } \\
\text { presence of random } \\
\text { effects (p-value) }\end{array}$ & Decision \\
\hline Real estate activities & 0.59 & 1.00 & Pooled regression \\
\hline $\begin{array}{l}\text { Professional, scientific research, } \\
\text { technical, administrative, support } \\
\text { service activities }\end{array}$ & 0.96 & 0.34 & Pooled regression \\
\hline $\begin{array}{l}\text { Public administration, compulsory } \\
\text { s.s., education, human health }\end{array}$ & 0.64 & 0.98 & Pooled regression \\
\hline Other service activities & 0.74 & 0.25 & Pooled regression \\
\hline
\end{tabular}

Source: Authors' own study based on the OECD database

The results in Table 11 indicate that the pooled regression model is the best choice for all the industries. Table 12 provides estimates of parameters for the variables $\triangle B E R D$ and $R E S$ for all 10 sectors. It should be stressed that variables that are not significant at the 0.1 level of significance are excluded from the final discussion.

Table 12: Results of the estimation of the parameters for different sectors

\begin{tabular}{|l|c|c|c|}
\hline \multicolumn{1}{|c|}{ Activity } & $\begin{array}{c}\text { Estimate for } \\
\text { intercept }\end{array}$ & $\begin{array}{c}\text { Estimate for } \\
\triangle B E R D\end{array}$ & Estimate for $R E S$ \\
\hline Agriculture, forestry, and fishing & 0.035 & - & $0.554^{* * *}$ \\
\hline Industry, including energy & $0.064^{* *}$ & $0.029^{* *}$ & - \\
\hline Construction & 0.023 & $0.065^{*}$ & - \\
\hline $\begin{array}{l}\text { Distributive trade, repairs, transport, } \\
\text { accommodation, food services }\end{array}$ & 0.029 & $0.044^{*}$ & - \\
\hline Information and communication & 0.019 & $0.012^{* *}$ & - \\
\hline Financial and insurance activities & 0.011 & $0.071^{*}$ & $0.098^{* *}$ \\
\hline Real estate activities & 0.021 & $0.153^{* *}$ & - \\
\hline $\begin{array}{l}\text { Professional, scientific research, } \\
\text { technical, administrative, support } \\
\text { service activities }\end{array}$ & 0.004 & - & $0.020^{* *}$ \\
\hline $\begin{array}{l}\text { Public administration, compulsory } \\
\text { s.s., education, human health }\end{array}$ & 0.030 & - & $0.010^{*}$ \\
\hline Other service activities & $0.045^{*}$ & - & $0.026^{* *}$ \\
\hline
\end{tabular}

Note: $* * *$ and $* * *$ denote significance at the $0.1,0.05$, and 0.01 levels of significance, respectively.

Source: Authors' own study based on the OECD database 


\section{Results and discussion}

Research and development (R\&D) expenditure as a percentage of gross domestic product (GDP) positively and significantly affects structural productivity growth. This means that a greater investment in $R \& D$ is associated with increasing employment rates in productive sectors and decreasing employment rates in less productive ones. This result, however, is in line with expectations, since findings from studies based on cross-country data indicate that an increase in R\&D should positively affect structural productivity growth as well as pure productivity growth (Guellec et al., 2004; Wang \& Huang, 2007; Wang, 2007). The obtained result may indicate that the absorptive capacity of the eight CEECs is limited and that the effect of increasing R\&D investments within the same sector seems to be weak.

The results of the estimation indicate that there are substantial differences between sectors in terms of the impact of business enterprise $R \& D$ expenditure growth and the number of researchers to the workforce ratio. The variable RES is statistically significant in 5 out of 10 equations, explaining the following sectors: agriculture, forestry, and fishing; financial and insurance activities; professional, scientific research, technical, administrative, and support service activities; public administration, compulsory s.s., education, and human health; and other service activities. For the more sophisticated services sectors, these results are not surprising, but the high value for the agriculture sector is astounding. Variable $\triangle B E R D$ is statistically significant in 6 out of 10 equations, explaining the following sectors: industry, including energy; construction; distributive trade, repairs, transport, accommodation, and food services; information and communication; financial and insurance activities; and real estate activities. It is worth underlining that only the financial and insurance activities sector exerts an impact on productivity for both $\triangle B E R D$ and $R E S$; this reflects the high level of innovation in this sector. Moreover, all the estimates of parameters are positive, which is in line with the expected impact of the variables on productivity change, presented in Table 4 .

\section{Conclusions}

The aim of this study was to analyse the structural and productivity changes of CCECs after their accession into the EU. The results of this analysis confirm that positive changes in productivity occurred both within and among structural components. The reallocation of employees to more modern and technologically advanced sectors can be noted in all the analysed countries. The cross-country comparisons demonstrate the same pattern and direction of employment reallocation in all the CEECs. In all the CEECs, a sustained decrease in the agriculture employment can be noted; this is the sector with the lowest productivity. Simultaneously, employment increased in the services sector, especially in the 
professional, scientific research, technical, administrative, and support service activities. Productivity increased in all sectors, but the most significant growth can be noted in the service sectors, including the areas of financial intermediation, real estate, renting, and business activities. During the research period, labour productivity growth within individual sectors can be observed; this is mainly courtesy of the improvement of technology and production processes. Both of these effects lead to an increase in economy-wide productivity. Moreover, it is worth underlining that sharing high-technology sectors led to an overall production increase over the research period in all the analysed countries.

This research also confirms that structural changes have played an important role in all the analysed CEECs' economies and made a positive contribution to overall growth. The impact of pure labour productivity has been much smaller. Undoubtedly, accession into the EU has a positive impact on the productivity level in CEECs' economies, which is evinced in the high productivity growth that occurred in almost all the analysed CEECs in the first four years after accession. The speed of change, however, differed between the countries in terms of pure and structural productivity change. Among the CEECs, productivity increased the most in Slovenia and the Baltic countries, while the lowest increase can be noted in Hungary. Other analysed countries also showed an increase in productivity growth, but the growth was less significant.

Additionally, the results of the panel data analysis confirm the significant impact of the evaluated factors on pure and structural productivity growth. Research and development (R\&D) expenditure as a percentage of gross domestic product (GDP) positively and significantly affects structural productivity growth. However, the obtained result indicate limited absorptive capacity of the eight CEECs, as the effect of increasing R\&D investments within the same sector seems to be weak. The ICT goods imports to total goods imports ratio exhibited positive and statistically significant impacts on pure and structural productivity change. Trade openness also has the positive and significant impact on pure and structural productivity. Furthermore, the results of the estimation of the parameters of the models explaining productivity growth confirm a positive impact of business enterprise R\&D expenditure growth and the number of researchers to the workforce ratio on sector productivity; however, the results indicate that there are substantial differences between sectors. The results of this study can be used by policymakers formulating policies. In CEE, countries' innovative capacities are still limited, and a more reasonable strategy would seem to promote a more gradual increase in R\&D spending; this may produce conditions that would be more conducive to innovation-driven growth. Policymakers should support R\&D expenditure, ICT use and trade openness.

There are a number of limitations associated with this study. The shift-share analysis technique is merely a descriptive tool and does not consider many factors, such as the impact of business cycles, identification of actual comparative advantages, and 
differences caused by levels of industrial detail. A shift-share analysis offers a glance at a local economy at two points in time. This technique should be used in combination with other methodologies to determine a country's economic potential. For this purpose, the authors additionally introduced panel analysis to increase the precision of research on structural changes. In addition, it would be worth considering whether the panel analysis should not include or replace variables; this is also the main limitation of this research. Furthermore, analysis of a longer period could foster more general conclusions and recommendations for policymakers. It is worth noting that this article could be enriched by an analysis from the beginning of the 1990s, but the data that could be found were sorted by different sector divisions, which prevented us from comparing this data. Moreover, further analysis could be enriched by an examination of marginal productivity at the sectoral and country levels, which can allow one to determine the optimal structure of the economy. Finally, this research could be improved through analysis at lower levels of regional aggregation, such as at the NUTS 2 or NUTS 3 level of regions, which could be investigated in further analysis. Some policy implications can be extracted from our analysis.

\section{References}

Andrikopoulos A., Brox, J. A. and Carvalho, E. (1990) "Shift-Share Analysis and the Potential for Predicting Regional Growth Patterns: Some Evidence for the Region of Quebec, Canada", Growth and Chane, 21, pp. 1-10.

Arcelus, F. (1984) “An extension of shift-share analysis". Growth and Change 15, pp. 3-8.

Arendt, L. \& Grabowski, W. (2017) "Innovations, ICT and ICT-driven labour productivity in Poland. A firm-level approach.” Economics of Transition, 25 (4), pp. 723-758, https://doi.org/10.1111/ecot.12135.

Bah, E. M., \& Brada, J. C. (2009) „Total Factor Productivity Growth, Structural Change and Convergence in the New Members of the European Union." Comparative Economic Studies, 51(4), 421-446, https://doi.org/10.1057/ces.2009.8.

Barff, R. A., \& Knight III, P. L. (1988) "Dynamic Shift-Share Analysis", Growth and Change, 19(2), pp. 1-10, https://doi.org/10.1111/j.1468-2257.1988.tb00465.x.

Bijsterbosch, M., \& Kolasa, M. (2010) "FDI and productivity convergence in Central and Eastern Europe: An industry-level investigation". Review of World Economics, 145, pp. 689-712.

Blundell, R., Bond, S. (1998) "Initial conditions and moment restrictions in dynamic panel data models." Journal of Econometrics, 87, pp. 115-143, https://ideas.repec.org/a/eee/econom/v87y1998i1p115-143.html.

Bouckaert, G., Nakrošis, V., \& Nemec, J. (2011) "Public Administration and Management Reforms in CEE: Main Trajectories and Results". NISPAcee 
Journal of Public Administration and Policy, 4(1), https://doi.org/10.2478/ v10110-011-0001-9.

Bregman, A., Fuss, M. \& Regev, H. (1991) "High tech and productivity: Evidence from Israeli industrial firms." European Economic Review, 35 (6), pp. 1199 1221, https://doi.org/10.1016/0014-2921(91)90115-Y.

Breusch, T.S., \& Pagan, A.R. (1980) "The Lagrange Multiplier test and its applications to model specification in econometrics." Review of Economic Studies, 47, pp. 239-253, https://www.jstor.org/stable/2297111.

Carmin, J., \& Vandeveer, S. D. (2004) "Enlarging EU Environments: Central and Eastern Europe from Transition to Accession". Environmental Politics, 13(1), pp. 3-24, https://doi.org/10.1080/09644010410001685119.

Crepon, B., Duguet E., Mairesse J. (1998) "Research, Innovation, and Productivity: An Econometric Analysis at the Firm Level.", Economics of Innovation and New Technology, 7 (2), pp. 115-158.

Dobrzanski, P. (2019) "Productivity performance of the Czech Republic - ShiftShare Analysis". In T. Loster \& T. Pavelka, T. Loster \& T. Pavelka (Eds.), The 13th International Days of Statistics and Economics : Conference Proceedings (pp. 317-326). Melandrium, https://doi.org/10.18267/pr.2019.los.186.31.

Dobrzanski, P., \& Olszewski L. (2019) "Structural Change Path and Economic Growth Performance of Polish Economy." In New Challenges of Economic and Business Development - 2019: Incentives for Sustainable Economic Growth. Proceedings, University of Latvia, pp. 230-39.

Duarte, M., \& Restuccia, D. (2010) "The Role of the Structural Transformation in Aggregate Productivity". Quarterly Journal of Economics, 125(1), pp. 129-173, https://doi.org/10.1162/qjec.2010.125.1.129.

Esteban-Marquillas, J.M. (1972) "A reinterpretation of shift-share analysis". Regional and Urban Economics 2, pp. 249-255.

Ezcurra R., Pascual P. (2007) "Spatial Disparities in Productivity in Central and Eastern Europe", Eastern European Economics, 45(3), pp. 5-32, https://doi. org/10.2753/EEE0012-8775450301.

Fabricant, S. (1942) "Employment in Manufacturing", 1899-1939. NBER, New York. Fagerberg, J. (2000) "Technological progress, structural change and productivity growth: a comparative study". Structural Change and Economic Dynamics, 11(4), pp. 393-411.

Fazlioglu, B., Dalgic, B. \& Yereli A.B. (2019) "The effect of innovation on productivity: evidence from Turkish manufacturing firms." Industry and Innovation, 26(4), pp. 439-460.

Friesenbichler, K., \& Peneder, M. (2016) "Innovation, competition and productivity". Economics of Transition, 24(3), pp. 535-580, https://doi. org/10.1111/ecot.12100. 
Guellec, D., \& Van Pottelsberghe de la Potterie, B. (2004) "From R\&D to Productivity Growth: Do the Institutional Settings and the Source of Funds of R\&D Matter?" Oxford Bulletin of Economics and Statistics, 66 (3), pp. 353378, https://doi.org/10.1111/j.1468-0084.2004.00083.x.

Habib M., Abbas J., Noman R., (2019) “Are human capital, intellectual property rights, and research and development expenditures really important for total factor productivity? An empirical analysis", International Journal of Social Economics, https://doi.org/10.1108/IJSE-09-2018-0472.

Hadri, K., (2000) "Testing for stationarity in heterogeneous panel data." Econometrics Journal, 3, pp. 148-161, https://www.jstor.org/stable/23114886?seq=1.

Hausman, J.A., (1978) "Specification tests in econometrics", Econometrica, 46(6), pp. 1251-1271, https://doi.org/10.2307/1913827.

Havlik, P. (2015) "Patterns of Structural Change in the New EU Member States". DANUBE: Law and Economics Review, 6(3), pp. 133-157, https://doi. org/10.1515/danb-2015-0009.

Knudsen, D. C. (2000) "Shift-share analysis: further examination of models for the description of economic change" Socio-Economic Planning Sciences, 34(3), pp. 177-198, https://doi.org/10.1016/s0038-0121(99)00016-6.

Kutan, A. M., Yigit, T. M. (2009) "European integration, productivity growth and real convergence: Evidence from the new member states". Economic Systems, 33(2), pp. 127-137, https://doi.org/10.1016/j.ecosys.2009.03.002.

Kuznets, S. (966). "Modern Economic Growth: Rate, Structure andSpread". Yale University Press, London.

Loveridge, S., \& Selting A.C. (1998) "A review and comparison of shift-share identities". International Regional Science Review, 21, pp. 37-58.

McMillan, M. \& Rodrik, D. (2011) "Globalization, Structural Change, and Productivity Growth". NBER Working Paper 17143.

Manning, N. (2004) "Diversity and Change in Pre-Accession Central and Eastern Europe Since 1989". Journal of European Social Policy, 14(3), pp. 211-232, https://doi.org/10.1177/0958928704044620.

Nazara, S., \& Hewings, G. J. D. (2004) "Spatial Structure and Taxonomy of Decomposition in Shift-Share Analysis". Growth and Change, 35(4), pp. 476-490.

Niţoi M. \& Pochea M. (2016) "Productivity clustering and growth in Central and Eastern Europe", Baltic Journal of Economics, 16(2), p. 151, https://doi.org/10. 1080/1406099X.2016.1189267.

Pesaran, M.H.(2004) "General diagnostic tests for cross section dependence in panels." University of Cambridge, Faculty of Economics, Cambridge Working Papers in Economics No. 0435.

Petreski, M., Jovanovic, B., \& Velickovski, I. (2017) "Tariff-Induced (De) industrialization: An Empirical Analysis". Comparative Economic Studies, 59(3), pp. 345-381, https://doi.org/10.1057/s41294-017-0030-8. 
Popescu, G. (2014) "FDI and Economic Growth in Central and Eastern Europe" Sustainability, 6 (11), pp. 8149-8163.

Radosevic, S. (2017) "Upgrading technology in Central and Eastern European economies". IZA World of Labor, p. 338, https://doi.org/10.15185/izawol.338.

Rowthorn, R., Ramaswamy, R. (1999) Growth, Trade and Deindustrialization, IMF Staff Papers, 46(1).

Silajdzic, S. \& Mehic, E. (2015) "Knowledge spillovers, absorptive capacities and the impact of FDI on economic growth: empirical evidence from transition economies." Procedia - Social and Behavioral Sciences, 195, pp. 614-623.

Sirakaya, E., Choi, H.-S., \& Var, T. (2002) "Shift-Share Analysis in Tourism: Examination of Tourism Employment Change in a Region." Tourism Economics, 8(3), pp. 303-324, https://doi.org/10.5367/000000002101298142.

Skorupinska A. \& Torrent-Sellens J. (2015) "The role of ICT in the productivity of Central and Eastern Europe an countries: cross-country comparison", Revista de Economía Mundial, 39, pp. 201-221.

Stevens, B. H. \& Moore, C. L. (1980) "A critical review of the literature on shiftshare as a forecasting technique". Journal of Regional Science, 20(4), pp. 419437, https://doi.org/10.1111/j.1467-9787.1980.tb00660.x.

Stojcic, N. \& Aralica, Z. (2018) "(De)industrialization and lessons for industrial policy in Central and Eastern Europe". Post Communist Economies, 30(6), pp. 713-734.

Stojcic, N. \& Orlic, E. (2019) Spatial dependence, foreign investment and productivity spillovers in new EU member states. Regional Studies. Online first, https://doi.org/10.1080/00343404.2019.1653451.

Stojcic, N., Vojinic, P. \& Aralica, Z. (2018) "Trade liberalization and export transformation in new EU member states." Structural Change and Economic Dynamics. 47, pp. 114-126.

Stojcic, N., Aralica, Z., \& Anic, I.-D. (2019) „Spatio-temporal determinants of the structural and productive transformation of regions in Central and East European countries". Economic Systems, Online first, https://doi.org/10.1016/j. ecosys.2019.100715.

Sun, W., Price, J. \& Ding, Y. (2019) "The longitudinal effects of internalization on firm performance: The moderating role of marketing capability." Journal of Business Research, 95, pp. 326-337, https://doi.org/10.1016/j.jbusres.2018.08.014.

Szczygielski, K., Grabowski, W. (2014) "Innovation strategies and productivity in the Polish services sector." Post-Communist Economies, 26(1), pp. 17-38, https://doi.org/10.1080/14631377.2014.874226.

Trasca, D. L., Ștefan, G. M., Sahlian, D. N., Hoinaru, R., \& Șerban-Oprescu, G.-L. (2019) "Digitalization and Business Activity. The Struggle to Catch Up in CEE Countries.” Sustainability, 11(8), p. 2204, https://doi.org/10.3390/su11082204. 
Wang, E.C. (2007) "R\&D efficiency and economic performance: A cross-country analysis using the stochastic frontier approach" Journal of Policy Modelling, 45 (4), pp. 770-784, https://doi.org/10.1016/j.respol.2016.01.003.

Wang, E.C. \& Huang, W. (2007) "Relative efficiency of R\&D activities: A crosscountry study accounting for environmental factors in the DEA approach" Research Policy, 36 (2), pp. 260-273, https://doi.org/10.1016/j.respol.2006.11.004.

Williamson, J. (1993) "Democracy and the Washington consensus" World Development, 21(8), pp. 1329-1336, https://doi.org/10.1016/0305-750x(93)90046-c.

Yilmaz G. (2015) "Decomposition of Labor Productivity Growth: Middle Income Trap and Graduated Countries", Working Papers 1527, Research and Monetary Policy Department, Central Bank of the Republic of Turkey.

\title{
Strukturalne i produktivne promjene zemalja srednje i istočne Europe ${ }^{1}$
}

\author{
Pawel Dobrzanski², Wojciech Grabowski ${ }^{3}$
}

\begin{abstract}
Sažetak
Svrha ovog rada je analizirati strukturalne i produktivne promjene zemalja srednje $i$ istočne Europe (CEE). Razdoblje istraživanja obuhvaća godine nakon pristupanja Europskoj uniji, od 2004. do 2018. godine. Ova studija želi odgovoriti na sljedeće pitanje: Koji su učinci rezultat integracije s Europskom unijom u području produktivnosti? Analiza pokriva dvije glavne kategorije rasta produktivnosti rada: čisti rast produktivnosti rada i strukturalni rast produktivnosti rada. Nadalje, ispituju se čimbenici koji mogu utjecati na čiste i strukturne promjene produktivnosti. Glavne metode istraživanja primijenjene u ovom radu su analiza pomaka udjela i metode panel podataka. Analiza pokazuje da su se u promatranom razdoblju sve zemlje
\end{abstract}

1 Projekt je financiran od strane Ministarstva znanosti i visokog obrazovanja u Poljskoj u okviru programa "Regionalna inicijativa izvrsnosti" 2019. - 2022. (Broj projekta 015 / RID / 2018/19). Ukupan iznos financiranja 10. 721. 040,00 PLN.

Zahvaljujemo profesoru Robertu J. Barru na njegovoj raspravi i komentarima na EDTKonferenciji Ekonomija digitalne transformacije "Pametne vlade, regije i gradovi", Opatija, 2. - 4. svibnja 2019.

2 Docent, Wroclaw University of Economics, Faculty of Economic Science, 118/120 Komandorska St, 53-345 Wroclaw, Poljska. Znanstveni interes: matematička ekonomija. Tel.: +48601594346, e-mail: pawel.dobrzanski@ue.wroc.pl.

Gostujuci znanstvenik, Department of Land Economy, University of Cambridge, 19 Silver Street, Cambridge, CB39EP Cambridge,Velika Britanija.E-mail: pm703@cam.ac.uk.

3 Docent, University of Lodz, Faculty of Economics and Sociology, 37/39 Rewolucji 1905 r. St, 90-214 Lodz, Poljska. Znanstveni interes: Modeli $i$ ekonometrijska predviđanja. Tel.: +48536039641,e-mail: Wojciech.Grabowski@uni.lodz.pl. 
središnje $i$ istočne Europe poboljšale $i$ u smislu čiste i strukturalne produktivnosti. Međutim, utjecaj čiste produktivnosti rada bio je znatno manji od utjecaja strukturalne produktivnosti rada; to znači da se glavna promjena na razini produktivnosti više može pripisati promjenama u zapošljavanju između sektora, nego li modernizaciji tehnoloških procesa. Produktivnost se povećala u svim sektorima, ali najznačajniji rast dogodio se u uslužnim sektorima, posebno u financijskim $i$ osiguravajućim djelatnostima i nekretninama. Istodobno, smanjila se zaposlenost u manje produktivnim sektorima, poput poljoprivrede, šumarstva i ribarstva. Nadalje, rezultati analize panel podataka potvrđuju značajan utjecaj procijenjenih faktora na čisti i strukturalni rast produktivnosti. Stoga, ukupna promjena produktivnosti na području Srednje i Istočne Europe može imati pozitivan utjecaj na oba oblika rasta produktivnosti. I strukturalni i čisti rast produktivnosti potiču ulaganje u istraživanje $i$ razvoj, uvoz roba informacijske $i$ komunikacijske tehnologije (IKT) $i$ otvorenost trgovine. Nadalje, ovo istraživanje potvrđuje pozitivan utjecaj koje ima povećanje ulaganja u istraživanje i razvoj poslovnih poduzeća i porast broja istraživača na omjer radne snage na produktivnost sektora, iako postoje bitne razlike između sektora. Ovo istraživanje mogu koristiti vladine agencije u izradi politika industrijskog razvoja.

Ključne riječi: strukturne promjene, produktivnost, analiza udjela pomaka, zemlje srednje i istočne Europe (CEEC), analiza panel podataka

JEL klasifikacija: F0, D24, G34, L33, P31 


\section{Appendices}

\begin{tabular}{|c|c|c|c|c|c|c|c|c|c|c|c|c|c|c|c|c|}
\hline 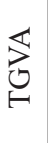 & $\stackrel{\infty}{\stackrel{\infty}{n}}$ & \begin{tabular}{l}
$\infty$ \\
in \\
\multirow{2}{0}{} \\
\multirow{\infty}{\infty}{}
\end{tabular} & $\begin{array}{l}\hat{\infty} \\
\frac{\infty}{n} \\
\hat{a}\end{array}$ & $\begin{array}{l}m \\
\infty \\
\overline{8}\end{array}$ & 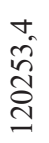 & $\begin{array}{l}\underset{b}{\vec{j}} \\
\underset{n}{\tilde{n}} \\
\stackrel{n}{n}\end{array}$ & 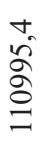 & 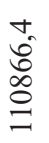 & 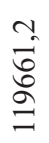 & $\begin{array}{l}\hat{0} \\
\text { ठ } \\
\frac{1}{5} \\
0\end{array}$ & 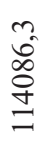 & $\begin{array}{l}2 \\
0 \\
0 \\
\infty \\
=\end{array}$ & $\begin{array}{c}\hat{\sigma} \\
\infty \\
\tilde{n} \\
\hat{0}\end{array}$ & $\begin{array}{l}n \\
n \\
n \\
0 \\
0\end{array}$ & $\begin{array}{l}\stackrel{+}{ \pm} \\
\underset{N}{\infty} \\
=\end{array}$ & $\begin{array}{l}\stackrel{2}{\infty} \\
\stackrel{N}{N} \\
\frac{n}{n}\end{array}$ \\
\hline $\begin{array}{l}\tilde{0} \\
0 \\
0\end{array}$ & $\begin{array}{l}0 \\
\hat{\infty} \\
\infty \\
\vec{\sim}\end{array}$ & $\begin{array}{l}{ }_{\infty} \\
\infty \\
\stackrel{n}{n} \\
\end{array}$ & $\begin{array}{l}\stackrel{0}{\stackrel{n}{n}} \\
\stackrel{\infty}{\sim}\end{array}$ & $\begin{array}{l}\nabla^{\prime} \\
\stackrel{\infty}{\infty}\end{array}$ & $\begin{array}{l}\stackrel{+}{n} \\
\stackrel{+}{m}\end{array}$ & $\begin{array}{l}\text { r } \\
\dot{\infty} \\
\stackrel{+}{+}\end{array}$ & 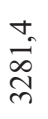 & $\underset{\text { N }}{\stackrel{\mathbb{N}}{N}}$ & $\begin{array}{l}\infty \\
\underbrace{\infty} \\
\stackrel{+}{+}\end{array}$ & $\begin{array}{l}n \\
\hat{\infty} \\
\infty \\
0 \\
\tilde{e}\end{array}$ & $\frac{n}{n}$ & $\begin{array}{l}+ \\
8 \\
0 \\
\dot{0}\end{array}$ & 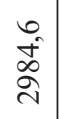 & $\stackrel{\overrightarrow{0}}{\stackrel{0}{n}}$ & $\frac{\mathfrak{n}}{\stackrel{m}{m}}$ & $\vec{n}$ \\
\hline $\begin{array}{l}\underset{Z}{Z} \\
\text { 岁 } \\
\dot{a}\end{array}$ & 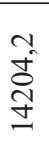 & 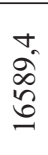 & $\begin{array}{l}m \\
\infty \\
\infty \\
\curvearrowright \\
I\end{array}$ & $\begin{array}{l}\vec{\Omega} \\
\text { مิ }\end{array}$ & $\begin{array}{l}\hat{\hat{N}} \\
\stackrel{0}{\mathbf{N}}\end{array}$ & 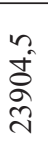 & \begin{tabular}{l}
0 \\
\multirow{2}{*}{} \\
2
\end{tabular} & $\begin{array}{l}\text { ले } \\
\text { वे }\end{array}$ & 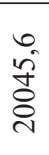 & 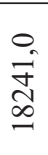 & $\begin{array}{l}\hat{\sigma} \\
\stackrel{0}{2}\end{array}$ & $\begin{array}{l}\infty \\
\text { ळิ } \\
\hat{\delta} \\
\text { ᄋे }\end{array}$ & $\begin{array}{c}\infty \\
\tilde{0} \\
0 \\
\simeq\end{array}$ & $\begin{array}{l}0 \\
\overline{8} \\
0\end{array}$ & $\stackrel{n}{\stackrel{n}{2}}$ & 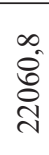 \\
\hline $\begin{array}{l}Z \\
\text { Z } \\
\text { ల } \\
\mathbb{\infty} \\
\infty\end{array}$ & $\underset{\vec{\infty}}{\vec{\Rightarrow}}$ & 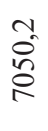 & $\begin{array}{l}\dot{\sigma}^{2} \\
\stackrel{2}{\infty} \\
\infty\end{array}$ & $\frac{0}{\infty}$ & 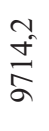 & $\begin{array}{l}\text { o } \\
\ddot{\circ} \\
\stackrel{2}{n} \\
=\end{array}$ & $\begin{array}{l}0 \\
n \\
\frac{n}{a}\end{array}$ & $\frac{\nabla_{0}}{\stackrel{2}{\sigma}}$ & \begin{tabular}{l}
$\infty$ \\
\multirow{2}{n}{} \\
$\hat{0}$
\end{tabular} & $\begin{array}{l}\text { त̂ } \\
\text { है } \\
\alpha\end{array}$ & $\begin{array}{l}m \\
\infty \\
m \\
\hat{\sigma}\end{array}$ & $\frac{1}{1}$ & $\begin{array}{l}0 \\
\tilde{\infty} \\
\tilde{\sigma}\end{array}$ & $\begin{array}{l}0 \\
\stackrel{2}{2} \\
\approx\end{array}$ & $\begin{array}{l}a \\
\tilde{o} \\
\triangleq \\
=\end{array}$ & 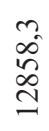 \\
\hline 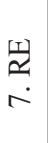 & $\begin{array}{l}\text { o } \\
\text { ర్ర } \\
\text { in }\end{array}$ & $\begin{array}{l}0 \\
\infty \\
2 \\
\hat{\sigma}\end{array}$ & $\begin{array}{l}n \\
8 \\
8 \\
0\end{array}$ & $\begin{array}{l}m \\
\stackrel{2}{\infty} \\
\infty \\
\infty\end{array}$ & $\begin{array}{l}\hat{~} \\
\hat{\sigma} \\
\text { aे }\end{array}$ & $\begin{array}{l}\hat{0} \\
\cong \\
\triangleq\end{array}$ & $\begin{array}{l}\stackrel{0}{1} \\
\text { ลे } \\
\text { à }\end{array}$ & 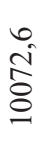 & $\begin{array}{l}\overrightarrow{\hat{0}} \\
\stackrel{0}{0}\end{array}$ & \begin{tabular}{l} 
aे \\
$\infty$ \\
\multirow{2}{\infty}{}
\end{tabular} & 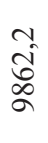 & $\overrightarrow{\stackrel{n}{\hat{n}}}$ & \begin{tabular}{l}
$\infty$ \\
\multirow{N}{N}{} \\
$\infty$
\end{tabular} & $\begin{array}{l}0 \\
0 \\
0 \\
0 \\
\infty\end{array}$ & $\frac{0}{=}$ & $\begin{array}{l}n \\
i \\
\tilde{\delta} \\
0\end{array}$ \\
\hline $\begin{array}{l}\text { Z } \\
\text { 至 } \\
\stackrel{0}{\circ}\end{array}$ & $\begin{array}{l}\infty \\
\stackrel{+}{S} \\
\stackrel{\infty}{n}\end{array}$ & $\begin{array}{l}\vec{n} \\
\infty \\
\infty\end{array}$ & $\begin{array}{l}n \\
\text { J্ర } \\
+\end{array}$ & 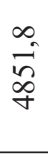 & \begin{tabular}{l}
$n$ \\
$\hat{o}$ \\
\multirow{2}{n}{}
\end{tabular} & $\begin{array}{l}n \\
\hat{n} \\
\tilde{n} \\
\tilde{n}\end{array}$ & $\begin{array}{l}0 \\
\infty \\
\infty \\
i n \\
n\end{array}$ & 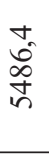 & $\begin{array}{l}\text { N } \\
\infty \\
\infty \\
\infty \\
n\end{array}$ & $\begin{array}{l}m \\
\infty \\
\infty \\
\infty\end{array}$ & $\frac{\substack{\infty \\
\infty}}{+}$ & $\begin{array}{l}0 \\
\infty \\
\infty \\
\dot{f}\end{array}$ & $\begin{array}{c}N \\
N \\
n \\
n\end{array}$ & $\underset{\mathfrak{N}}{\mathfrak{N}}$ & $\begin{array}{l}\vec{f} \\
\stackrel{f}{f}\end{array}$ & $\begin{array}{c}\infty \\
\tilde{n} \\
\tilde{f}\end{array}$ \\
\hline $\begin{array}{l}\text { o } \\
\text { Z } \\
\text { in } \\
\text { in }\end{array}$ & $\underset{\tilde{\infty}}{\tilde{\infty}}$ & $\stackrel{n}{\tilde{a}}$ & $\frac{\gamma}{\hat{a}}$ & $\begin{array}{l}\frac{\sigma_{n}}{\sigma} \\
\frac{1}{n}\end{array}$ & 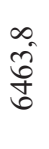 & 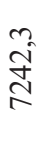 & 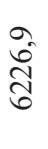 & $\begin{array}{l}\text { ชू } \\
\text { ஜूँ } \\
\text { in }\end{array}$ & 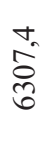 & 包 & $\begin{array}{l}\overrightarrow{\tilde{t}} \\
\stackrel{0}{0}\end{array}$ & $\frac{m}{\sigma}$ & $\frac{\infty}{i} \underset{0}{n}$ & $\begin{array}{l}\text { No } \\
\text { N } \\
\tilde{n} \\
n\end{array}$ & 光 & $\begin{array}{l}\infty \\
i \\
i n \\
\sigma\end{array}$ \\
\hline 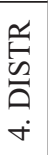 & $\begin{array}{l}n \\
\approx \\
\stackrel{\tilde{D}}{0} \\
=\end{array}$ & $\begin{array}{l}0 \\
\infty \\
\infty \\
\infty \\
n \\
n\end{array}$ & $\frac{n}{\hat{\sigma}}$ & $\begin{array}{c}\hat{a} \\
\substack{\infty \\
\text { I }}\end{array}$ & 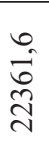 & 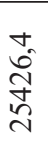 & 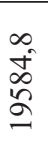 & $\begin{array}{l}0 \\
\stackrel{2}{ } \\
\check{2} \\
\cong\end{array}$ & 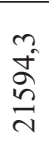 & $\begin{array}{l}\infty \\
\stackrel{0}{0} \\
\stackrel{2}{\sigma}\end{array}$ & $\begin{array}{l}\stackrel{0}{\Omega} \\
\stackrel{\Omega}{\sim}\end{array}$ & 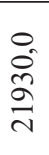 & 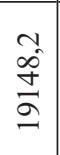 & $\begin{array}{l}\hat{\sigma} \\
\hat{\sigma} \\
\hat{\sigma}\end{array}$ & 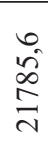 & $\begin{array}{l}0 \\
\stackrel{0}{0} \\
\stackrel{7}{\sim}\end{array}$ \\
\hline $\begin{array}{l}n \\
Z \\
0 \\
\text { en } \\
\dot{r}\end{array}$ & $\frac{a}{n}$ & $\begin{array}{l}\infty \\
\stackrel{\infty}{+} \\
\stackrel{f}{\sigma}\end{array}$ & $\begin{array}{l}0 \\
\varnothing \\
\varnothing \\
n\end{array}$ & $\begin{array}{l}\nabla_{n} \\
m \\
m \\
m\end{array}$ & ๙ू. & 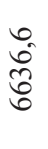 & 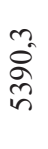 & $\begin{array}{l}n \\
n \\
\tilde{b} \\
y\end{array}$ & $\stackrel{2}{\stackrel{2}{\circ}}$ & $\frac{m}{\underset{\gamma}{+}}$ & $\begin{array}{l}2 \\
2 \\
\sigma\end{array}$ & $\begin{array}{l}0 \\
\infty \\
\infty \\
\infty \\
i n\end{array}$ & $\stackrel{\hat{N}}{\stackrel{N}{f}}$ & $\begin{array}{l}0 \\
\dot{f} \\
\stackrel{n}{n}\end{array}$ & $\hat{\bar{n}}$ & $\vec{\delta}$ \\
\hline 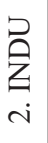 & $\begin{array}{l}0 \\
\hat{N} \\
\tilde{\infty} \\
\infty \\
-\end{array}$ & 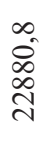 & $\begin{array}{l}\infty \\
\stackrel{n}{2} \\
\stackrel{\infty}{\sim} \\
\stackrel{+}{N}\end{array}$ & $\begin{array}{l}\stackrel{+}{\circ} \\
\infty \\
\infty \\
\end{array}$ & $\begin{array}{l}2 \\
\stackrel{m}{\rho} \\
\stackrel{m}{m}\end{array}$ & 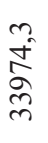 & $\begin{array}{l}\approx \\
\stackrel{n}{\approx} \\
\tilde{n}\end{array}$ & $\begin{array}{l}n \\
\tilde{0} \\
\infty \\
\infty \\
\sim\end{array}$ & $\begin{array}{l}\stackrel{0}{0} \\
\stackrel{n}{\infty} \\
\stackrel{\infty}{0}\end{array}$ & $\begin{array}{l}n \\
\stackrel{n}{n} \\
\stackrel{\infty}{N}\end{array}$ & 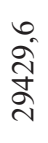 & $\begin{array}{l}\vec{\Xi} \\
\vec{\Xi}\end{array}$ & 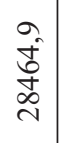 & 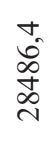 & $\begin{array}{l}0 \\
n \\
\infty \\
0 \\
0 \\
\text { no }\end{array}$ & $\begin{array}{l}\hat{n} \\
\hat{n} \\
\hat{m}\end{array}$ \\
\hline 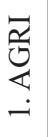 & $\begin{array}{l}0 \\
\vec{\infty} \\
\stackrel{0}{n}\end{array}$ & 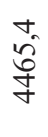 & $\begin{array}{l}0 \\
\stackrel{0}{n} \\
\frac{1}{\gamma}\end{array}$ & 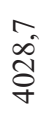 & 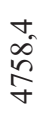 & $\begin{array}{l}\nabla_{n} \\
\frac{n}{n}\end{array}$ & $\underset{\substack{\infty \\
m}}{\stackrel{a}{n}}$ & $\begin{array}{l}\dot{\sigma}_{0} \\
\stackrel{\circ}{\sigma}\end{array}$ & ڤू & $\frac{\hat{\sigma}}{\frac{\sigma}{\sigma}}$ & $\begin{array}{l}\infty \\
\hat{i} \\
\tilde{n}\end{array}$ & $\begin{array}{l}n \\
\tilde{n} \\
n \\
n\end{array}$ & $\begin{array}{l}- \\
\dot{0} \\
\dot{d}\end{array}$ & $\vec{a}$ & $\overrightarrow{\tilde{f}}$ & 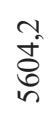 \\
\hline 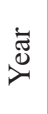 & ֻి & ষ্ণ & 苂 & ஓి & $\stackrel{\widehat{্}}{8}$ & $\stackrel{\infty}{8}$ & 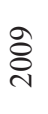 & $\stackrel{\circ}{\stackrel{\circ}{\sim}}$ & $\bar{\Xi}$ & $\stackrel{\sim}{\stackrel{\sim}{*}}$ & $\stackrel{m}{\stackrel{n}{\sigma}}$ & $\underset{\sim}{\stackrel{\sim}{\sim}}$ & $\stackrel{n}{\stackrel{n}{N}}$ & 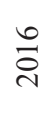 & 롯 & $\stackrel{\infty}{\stackrel{\sim}{\sim}}$ \\
\hline
\end{tabular}




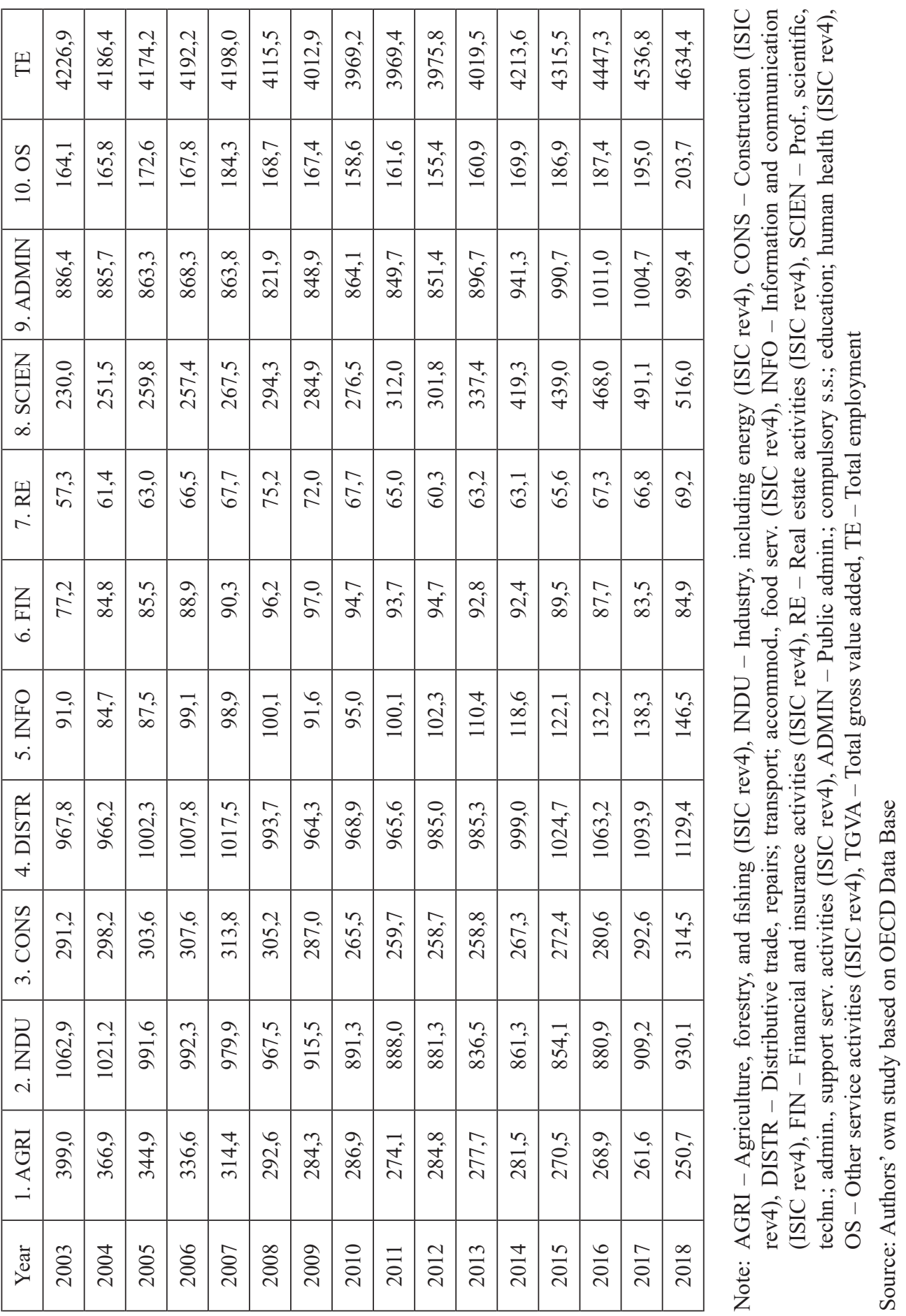




\begin{tabular}{|c|c|c|c|c|c|c|c|c|c|c|c|c|c|c|c|c|}
\hline 岁 & $\begin{array}{l}0 \\
\text { î } \\
\delta \\
\text { d }\end{array}$ & 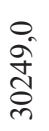 & 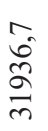 & 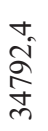 & $\begin{array}{l}\hat{b} \\
\stackrel{0}{ } \\
\vec{\Im}\end{array}$ & $\begin{array}{l}\hat{n} \\
\hat{\delta} \\
\infty \\
+ \\
+\end{array}$ & $\begin{array}{l}\hat{\vec{n}} \\
\hat{\sigma} \\
\bar{\sigma}\end{array}$ & $\begin{array}{l}\hat{\infty} \\
\tilde{N} \\
\infty \\
\vec{\sigma}\end{array}$ & $\begin{array}{l}\hat{\sigma} \\
\text { on } \\
\text { bo } \\
\text { J }\end{array}$ & 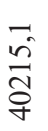 & 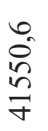 & $\underset{\stackrel{\vartheta}{\vartheta}}{\stackrel{0}{\vartheta}}$ & 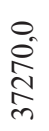 & $\begin{array}{l}\hat{b} \\
\hat{\delta} \\
\infty \\
n\end{array}$ & 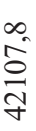 & $\begin{array}{l}0 \\
0 \\
\stackrel{0}{N} \\
\stackrel{f}{f}\end{array}$ \\
\hline 0 & $\begin{array}{l}n \\
\stackrel{f}{r}\end{array}$ & $\underset{\infty}{\stackrel{n}{\infty}}$ & $\begin{array}{l}\stackrel{0}{\sigma} \\
\stackrel{\Xi}{G}\end{array}$ & $\frac{a}{\hat{a}}$ & $\begin{array}{l}\stackrel{N}{\infty} \\
\Xi \\
\Xi\end{array}$ & 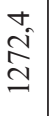 & $\begin{array}{l}\tilde{\Xi} \\
\underline{\Xi}\end{array}$ & $\begin{array}{l}\hat{n} \\
\hat{n} \\
\underline{\Xi}\end{array}$ & 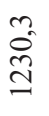 & $\begin{array}{l}\stackrel{n}{0} \\
\stackrel{0}{=}\end{array}$ & $\stackrel{n}{\beth}$ & 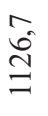 & $\stackrel{-}{a}$ & $\stackrel{i}{0}$ & $\begin{array}{l}\hat{\sigma} \\
\equiv \\
=\end{array}$ & $\begin{array}{l}0 \\
\text { d } \\
\text { I }\end{array}$ \\
\hline
\end{tabular}

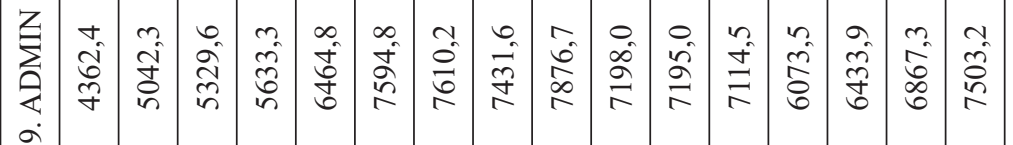




\begin{tabular}{|c|c|c|c|c|c|c|c|c|c|c|c|c|c|c|c|c|}
\hline 岂 & $\stackrel{m}{n}$ & $\begin{array}{l}0 \\
\text { ஸे } \\
\text { â }\end{array}$ & ๙ิ & $\overrightarrow{J^{\prime}}$ & $\frac{\infty}{n}$ & $\begin{array}{l}\infty \\
8 \\
8\end{array}$ & $\begin{array}{l}\hat{~} \\
\text { ô }\end{array}$ & तु & $\begin{array}{l}0 \\
\text { o. } \\
\text { \& }\end{array}$ & $\frac{N}{n}$ & $\begin{array}{l}\hat{\sigma} \\
\text { న }\end{array}$ & 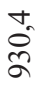 & \begin{tabular}{l}
0 \\
$\stackrel{1}{*}$ \\
\multirow{2}{*}{}
\end{tabular} & $\stackrel{n}{2}$ & $\begin{array}{l}\infty \\
\hat{\infty} \\
\sigma\end{array}$ & $\frac{n}{2}$ \\
\hline$\tilde{0}$ & $\stackrel{\infty}{\infty} \underset{\sim}{\infty}$ & $\stackrel{n}{\sim}$ & $\stackrel{\circ}{\text { กิ }}$ & $\vec{\curvearrowright}$ & ?n & $\frac{0}{m}$ & $\begin{array}{l}0 \\
\text { ñ }\end{array}$ & กे & ñ & ñ & $\stackrel{n}{n}$ & $n$ & గి & $n$ & $\stackrel{\infty}{\infty}$ & $\begin{array}{l}0 \\
\stackrel{f}{+}\end{array}$ \\
\hline 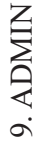 & $\begin{array}{l}0 \\
\text { N } \\
n\end{array}$ & 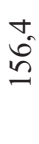 & \begin{tabular}{l}
\multirow{2}{*}{} \\
$\stackrel{n}{n}$
\end{tabular} & $\stackrel{\infty}{\sigma}$ & $\begin{array}{l}0 \\
\text { త్ }\end{array}$ & $\begin{array}{l}0 \\
0 \\
0 \\
0\end{array}$ & $\hat{\sigma}$ & $\stackrel{n}{\approx}$ & $\stackrel{2}{2}$ & 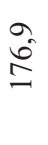 & $\begin{array}{l}\infty \\
\stackrel{n}{N}\end{array}$ & 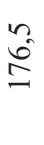 & $\stackrel{\Omega}{\Omega}$ & 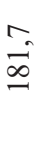 & $\begin{array}{l}\sigma_{0} \\
\infty\end{array}$ & $\vec{\circ}$ \\
\hline 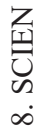 & $\begin{array}{l}\tilde{g} \\
\dot{a}\end{array}$ & $\stackrel{{ }_{0}}{\stackrel{\infty}{\alpha}}$ & $\stackrel{\infty}{a}$ & ล̊. & $\begin{array}{l}\nabla_{0} \\
\stackrel{\infty}{0}\end{array}$ & $\stackrel{0}{\equiv}$ & $\stackrel{n}{\varrho}$ & $\begin{array}{l}0 \\
\cong\end{array}$ & $\vec{\Xi}$ & $\begin{array}{l}0 \\
\pm \\
\pm\end{array}$ & $\stackrel{n}{ \pm}$ & $\begin{array}{l}\infty \\
\infty\end{array}$ & $\stackrel{\sigma}{\sim}$ & $\stackrel{\Xi}{\text { J }}$ & $\frac{n}{n}$ & $\begin{array}{l}n \\
\stackrel{n}{2}\end{array}$ \\
\hline $\begin{array}{l}\frac{1}{\alpha} \\
\stackrel{N}{~}\end{array}$ & $\hat{m}$ & $\vec{m}$ & $\hat{\sigma}$ & $\stackrel{m}{\sigma}$ & $\stackrel{\infty}{\forall}$ & ? & $n$ & $n$ & $\begin{array}{l}\nabla_{0} \\
\text { in }\end{array}$ & n & n & $\nabla_{n}$ & $n$ & $\hat{n}$ & $\overrightarrow{6}$ & "ู \\
\hline 光 & $\stackrel{\vec{\sim}}{\vec{N}}$ & ָ̃ & กิ & $\vec{\sim}$ & $\stackrel{a}{\text { กे }}$ & $\begin{array}{l}0 \\
\stackrel{2}{n}\end{array}$ & nิ & ๙ & \begin{tabular}{l}
0 \\
\multirow{d}{*}{}
\end{tabular} & 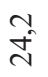 & $\stackrel{\sim}{\sim}$ & ते & กิ & กิ & $\begin{array}{l}0 \\
\text { Nิ }\end{array}$ & $\vec{\sim}$ \\
\hline $\begin{array}{l}0 \\
\text { Z } \\
\text { Z }\end{array}$ & $\infty$ & $\begin{array}{l}0 \\
\infty \\
\infty\end{array}$ & 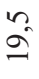 & $\stackrel{\curvearrowright}{\curvearrowright}$ & กิ & $\stackrel{\infty}{\curvearrowright}$ & $\stackrel{\infty}{\stackrel{\infty}{\sim}}$ & $\stackrel{0}{\sim}$ & $\stackrel{\circ}{\sim}$ & $\begin{array}{c}0 \\
\text { กิ }\end{array}$ & స్ & $\vec{\vartheta}_{\hat{\sigma}}$ & $\hat{N}$ & $\stackrel{\sim}{\sim}$ & $\stackrel{\infty}{\curvearrowright}$ & $\underset{m}{\stackrel{0}{m}}$ \\
\hline 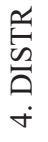 & $\begin{array}{l}\text { N } \\
\infty \\
\infty\end{array}$ & $\begin{array}{l}\infty \\
\infty \\
\infty\end{array}$ & $\stackrel{\Omega}{\Omega}$ & $\begin{array}{l}\text { గ్ } \\
2\end{array}$ & $\hat{\tilde{\rho}}$ & $\stackrel{\widetilde{\Omega}}{\approx}$ & $\frac{\widetilde{N}}{\sim}$ & $\stackrel{n}{\stackrel{n}{2}}$ & 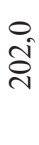 & $\begin{array}{l}0 \\
\stackrel{2}{a}\end{array}$ & $\tilde{a}$ & $\begin{array}{l}0 \\
0 \\
0\end{array}$ & 흉 & $\begin{array}{l}0 \\
\stackrel{2}{2} \\
\stackrel{2}{2}\end{array}$ & $\underset{\partial}{\approx}$ & $\frac{\infty}{\infty}$ \\
\hline ¿ & $\tilde{6}$ & గ్ర & $\overbrace{}^{2}$ & $\stackrel{\infty}{i}$ & $\vec{\infty}$ & ๙̃ & $\frac{n}{a}$ & $\stackrel{0}{\infty}$ & $\stackrel{N}{N}$ & $\tilde{6}$ & ๙ె. & กิ & $\begin{array}{l}0 \\
\text { ชิ }\end{array}$ & $\frac{a}{6}$ & $\hat{n}$ & $\tilde{6}$ \\
\hline 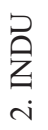 & ?ֶ. & $\begin{array}{l}\text { No } \\
\infty \\
\sim\end{array}$ & $\begin{array}{c}n \\
\tilde{n} \\
\tilde{n}\end{array}$ & $\stackrel{\infty}{\stackrel{\infty}{\sim}}$ & $\frac{a}{n}$ & $\frac{0}{n}$ & กิ & $\frac{n}{\sqrt{n}}$ & $\begin{array}{l}0 \\
\stackrel{0}{\sim} \\
\sim\end{array}$ & $\frac{0}{n}$ & $\stackrel{n}{\circ}$ & $\begin{array}{l}\overrightarrow{0} \\
\vec{N}\end{array}$ & $\stackrel{\sim}{\sim}$ & $\frac{\nabla_{n}}{\sim}$ & $\stackrel{n}{\stackrel{\sim}{N}}$ & $\begin{array}{l}\text { ๙̃ } \\
\text { ஸे }\end{array}$ \\
\hline 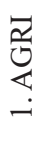 & $\stackrel{n}{n}$ & ลे & ֻু & $\begin{array}{l}0 \\
\infty \\
\infty\end{array}$ & $\begin{array}{l}0 \\
\infty \\
\infty\end{array}$ & $\stackrel{\sim}{\infty}$ & $\stackrel{\vec{\infty}}{A}$ & $\stackrel{\circ}{\circ}$ & $\underset{\infty}{\infty}$ & $\stackrel{m}{N}$ & $\stackrel{N}{N}$ & $\stackrel{a}{n}$ & $\stackrel{n}{n}$ & $\stackrel{m}{\mathbb{N}}$ & $\stackrel{n}{n}$ & $\stackrel{N}{N}$ \\
\hline 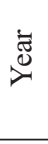 & હ̊ & ঠి & §̊ & ๖̊ & $\hat{\delta}$ & $\stackrel{\infty}{\stackrel{\overbrace{}}{\circ}}$ & ஓి & $\stackrel{\circ}{\stackrel{0}{\circ}}$ & 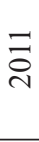 & $\stackrel{N}{\stackrel{ }{\sigma}}$ & $\stackrel{n}{\frac{n}{2}}$ & 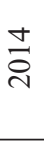 & $\stackrel{n}{\circ}$ & $\stackrel{0}{\stackrel{0}{0}}$ & $\stackrel{\bar{D}}{\stackrel{\nu}{ }}$ & $\stackrel{\infty}{\underset{\sim}{\sigma}}$ \\
\hline
\end{tabular}




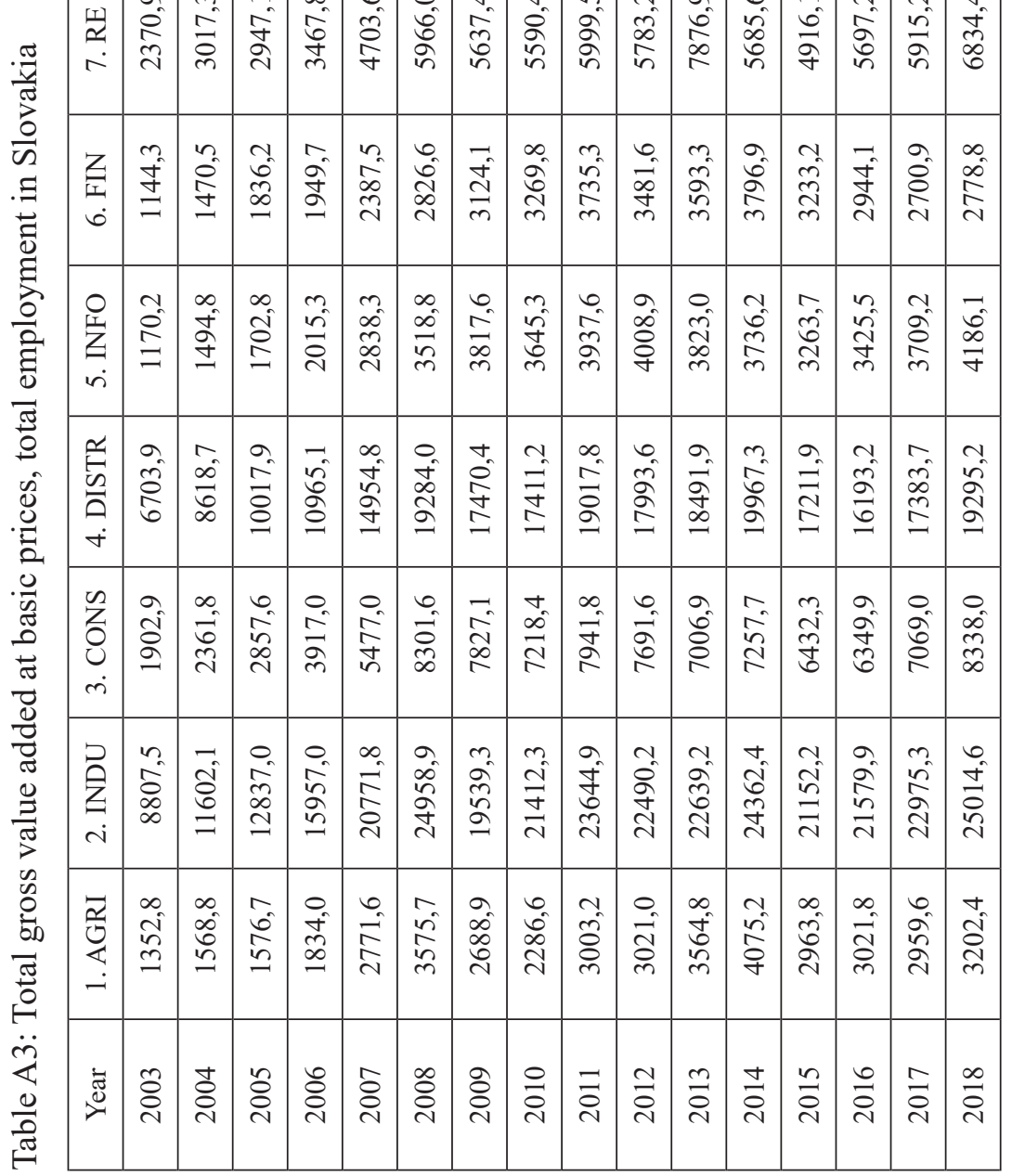

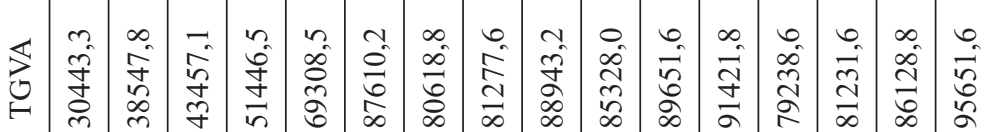

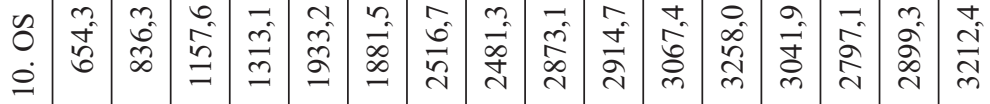

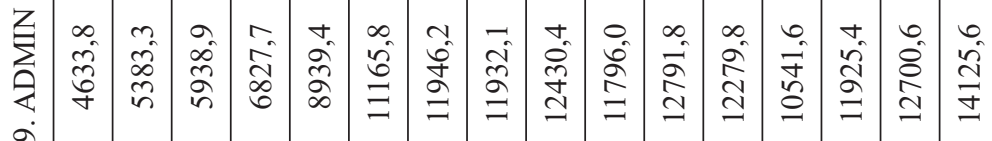

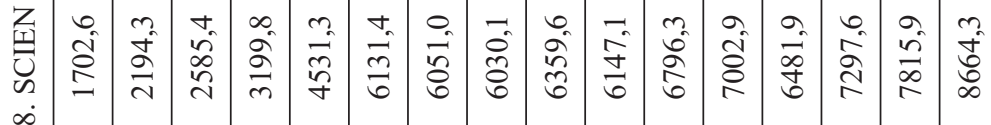

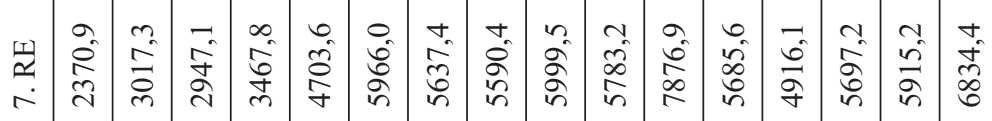




\begin{tabular}{|c|c|c|c|c|c|c|c|c|c|c|c|c|c|c|c|c|}
\hline$\stackrel{I}{\ominus}$ & $\begin{array}{l}n \\
\tilde{8} \\
\stackrel{8}{2} \\
\end{array}$ & $\begin{array}{l}\hat{n} \\
\hat{n}\end{array}$ & $\begin{array}{l}\hat{\infty} \\
\infty \\
\infty \\
\overbrace{}^{\infty}\end{array}$ & $\begin{array}{l}\stackrel{v}{d} \\
\stackrel{\sim}{\sim} \\
\stackrel{\sim}{v}\end{array}$ & $\frac{O}{\stackrel{N}{N}}$ & 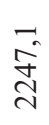 & 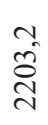 & $\begin{array}{l}\infty \\
\stackrel{\infty}{0} \\
\stackrel{\sim}{v}\end{array}$ & 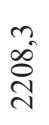 & $\begin{array}{l}\sigma_{0} \\
\text { Оे } \\
\text { ते }\end{array}$ & $\begin{array}{l}\hat{\sim} \\
\hat{\sigma} \\
\hat{\sim}\end{array}$ & 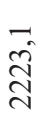 & $\begin{array}{l}\overrightarrow{\widehat{\omega}} \\
\stackrel{\sim}{N}\end{array}$ & $\begin{array}{l}\stackrel{0}{\vec{N}} \\
\underset{\sim}{\Delta}\end{array}$ & 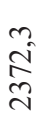 & $\begin{array}{l}\hat{\sigma} \\
\stackrel{\vec{v}}{\sim}\end{array}$ \\
\hline $\begin{array}{l}\mathscr{2} \\
0 \\
\dot{0}\end{array}$ & $\begin{array}{l}0 \\
i \\
i\end{array}$ & 䓂 & in & $\overrightarrow{6}$ & $\stackrel{0}{i n}$ & $\begin{array}{l}\infty \\
\text { î }\end{array}$ & के & के & $\begin{array}{l}2 \\
\hat{n}\end{array}$ & in & $\begin{array}{l}0 \\
\text { in }\end{array}$ & $\stackrel{\infty}{\vec{b}}$ & $\hat{\tilde{\sigma}}$ & $\frac{0}{6}$ & $\begin{array}{l}0 \\
\stackrel{R}{0}\end{array}$ & $\frac{N}{i}$ \\
\hline 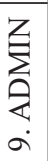 & $\stackrel{\sim}{\dot{f}}$ & $\stackrel{+}{\stackrel{\nabla}{f}}$ & $\vec{F}$ & $\hat{\tilde{g}}$ & $\begin{array}{l}\dot{f}^{\prime} \\
\stackrel{f}{*}\end{array}$ & \begin{tabular}{l}
$\infty$ \\
$\infty$ \\
\multirow{+}{*}{}
\end{tabular} & $\begin{array}{l}\overrightarrow{8} \\
\stackrel{n}{7}\end{array}$ & $\begin{array}{l}0 \\
\text { if } \\
\stackrel{f}{f}\end{array}$ & $\stackrel{n}{n}$ & 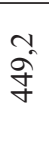 & $\begin{array}{l}3 \\
\infty \\
\dot{y}\end{array}$ & $\frac{n}{n}$ & $\begin{array}{c}\text { ช̂ } \\
\text { bे }\end{array}$ & $\begin{array}{l}n \\
\infty \\
0 \\
+\end{array}$ & $\stackrel{n}{\stackrel{\sim}{f}}$ & $\hat{\stackrel{\infty}{\circ}}$ \\
\hline $\begin{array}{l}\underset{1}{Z} \\
\text { 崩 } \\
\infty \\
\infty\end{array}$ & $\begin{array}{l}n \\
\stackrel{n}{-}\end{array}$ & $\begin{array}{l}\text { ô } \\
\text { I }\end{array}$ & $\frac{n}{6}$ & $\hat{\tilde{\sigma}}$ & $\begin{array}{l}0 \\
\stackrel{0}{2}\end{array}$ & $\underset{\infty}{\infty}$ & $\begin{array}{l}0 \\
\stackrel{\infty}{\infty}\end{array}$ & ڤू. & $\begin{array}{l}0 \\
\infty \\
\stackrel{0}{=}\end{array}$ & $\begin{array}{l}\stackrel{n}{ \pm} \\
\stackrel{\sim}{N}\end{array}$ & $\begin{array}{l}\stackrel{0}{0} \\
\stackrel{0}{N}\end{array}$ & $\frac{\dot{\sigma}_{0}}{\stackrel{\sim}{\sigma}}$ & 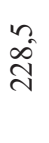 & ๗ิ & $\underset{\vec{J}}{\stackrel{a}{J}}$ & $\vec{a}$ \\
\hline $\begin{array}{l}\frac{1}{\simeq} \\
r\end{array}$ & $\begin{array}{l}2 \\
\infty\end{array}$ & $\stackrel{\nabla_{n}}{\stackrel{2}{\Xi}}$ & $\begin{array}{l}m \\
\Omega\end{array}$ & $\begin{array}{l}n \\
2\end{array}$ & $\overrightarrow{\tilde{d}}$ & $\hat{\sigma}$ & $\begin{array}{l}0 \\
\stackrel{2}{2}\end{array}$ & $\stackrel{0}{\vec{\lambda}}$ & $\begin{array}{l}\stackrel{0}{+} \\
\stackrel{\sim}{ }\end{array}$ & $\begin{array}{l}\stackrel{+}{\sim} \\
\stackrel{\sim}{ }\end{array}$ & $\begin{array}{l}\hat{\mathrm{d}} \\
\text { in }\end{array}$ & 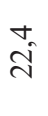 & $\begin{array}{l}0 \\
\text { i }\end{array}$ & $\begin{array}{l}\vec{v} \\
\stackrel{\sim}{n}\end{array}$ & $\stackrel{\overbrace{}}{\hat{\imath}}$ & 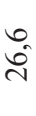 \\
\hline $\begin{array}{l}\underset{I}{Z} \\
\stackrel{0}{0}\end{array}$ & $\stackrel{\bar{m}}{\bar{m}}$ & $\stackrel{\infty}{m}$ & $\stackrel{m}{\stackrel{m}{m}}$ & $\begin{array}{l}\nabla_{0} \\
\text { no }\end{array}$ & $\begin{array}{c}0 \\
\infty \\
\infty \\
m\end{array}$ & $\vec{\nexists}$ & $\stackrel{?}{\underset{\gamma}{\gamma}}$ & $\vec{q}$ & $\begin{array}{l}0 \\
\mathscr{q}\end{array}$ & $\stackrel{\infty}{\vec{\nabla}}$ & $\stackrel{\underset{f}{f}}{\stackrel{\sim}{f}}$ & $\stackrel{\vartheta}{\tilde{f}}$ & $\hat{f}$ & $\begin{array}{l}t_{\sigma} \\
\dot{f}\end{array}$ & $\begin{array}{l}0 \\
\text { o }\end{array}$ & $\overrightarrow{6}$ \\
\hline $\begin{array}{l}\text { O } \\
\text { 崖 } \\
\text { in }\end{array}$ & $\frac{0}{\vec{\nabla}}$ & $\begin{array}{l}\dot{\sigma}_{\sigma} \\
\dot{q}\end{array}$ & $\begin{array}{l}0 \\
\mathcal{J}\end{array}$ & గo & $\underset{+}{\sim}$ & $\frac{0}{n}$ & $\begin{array}{l}\sigma_{0} \\
\text { ñ }\end{array}$ & $\stackrel{2}{n}$ & $\begin{array}{l}\vec{n} \\
n\end{array}$ & $\vec{n}$ & $\begin{array}{l}0 \\
\text { in }\end{array}$ & ñ & $\hat{8}$ & $\begin{array}{l}\text { I } \\
\text { t }\end{array}$ & $\overrightarrow{6}$ & $\begin{array}{l}0 \\
\text { aे }\end{array}$ \\
\hline 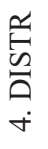 & $\frac{\infty}{\curvearrowright}$ & $\begin{array}{l}\hat{\sigma} \\
\hat{n}\end{array}$ & $\hat{\widehat{D}}$ & $\begin{array}{l}0 \\
i n \\
i n\end{array}$ & $\begin{array}{l}0 \\
\text { in }\end{array}$ & $\begin{array}{l}\nabla_{n} \\
\stackrel{n}{n}\end{array}$ & $\begin{array}{l}\nabla_{n} \\
\stackrel{n}{n}\end{array}$ & $\begin{array}{l}\text { గn } \\
\infty \\
\infty \\
n\end{array}$ & $\begin{array}{l}\infty \\
\mathscr{b}^{\circ} \\
\text { in }\end{array}$ & $\begin{array}{l}\hat{y} \\
\infty \\
\text { ळे }\end{array}$ & ñ & 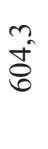 & $\begin{array}{l}\stackrel{0}{0} \\
\stackrel{8}{0}\end{array}$ & $\begin{array}{l}\infty \\
i \\
\sigma\end{array}$ & 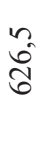 & $\begin{array}{l}\text { बे } \\
\text { శె }\end{array}$ \\
\hline 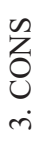 & $\vec{n}$ & $\begin{array}{l}0 \\
\stackrel{0}{=}\end{array}$ & $\begin{array}{l}0 \\
\text { in } \\
n\end{array}$ & $\stackrel{m}{n}$ & $\begin{array}{l}0 \\
0 \\
0\end{array}$ & $\stackrel{0}{\infty}$ & $\frac{n}{\infty}$ & $\stackrel{\infty}{\infty}$ & $\stackrel{n}{\stackrel{n}{=}}$ & $\stackrel{\infty}{=}$ & $\begin{array}{l}n \\
\stackrel{0}{0} \\
0\end{array}$ & 胥 & శె & $\begin{array}{l}\infty \\
\tilde{b}\end{array}$ & $\hat{\sigma}$ & 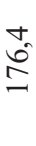 \\
\hline $\begin{array}{l}\stackrel{?}{2} \\
\stackrel{2}{Z} \\
\text { ¿ }\end{array}$ & $\begin{array}{l}m \\
\infty \\
\infty \\
\infty\end{array}$ & $\begin{array}{l}0 \\
\delta^{\circ} \\
i n\end{array}$ & $\begin{array}{l}0 \\
0 \\
i n \\
i n\end{array}$ & $\begin{array}{l}\overrightarrow{6} \\
i n\end{array}$ & $\underset{n}{m}$ & $\hat{\sigma}$ & $\begin{array}{l}\hat{o} \\
\hat{n}\end{array}$ & $\stackrel{\infty}{=}$ & $\hat{\curvearrowright}$ & $\begin{array}{l}\infty \\
\stackrel{\Delta}{N} \\
\text { N }\end{array}$ & $\overrightarrow{\vec{\infty}}$ & $\begin{array}{l}\text { N } \\
\text { in }\end{array}$ & $\begin{array}{l}\hat{n} \\
i n\end{array}$ & $\begin{array}{l}\vec{b} \\
\ddot{n}\end{array}$ & $\begin{array}{l}\text { no } \\
\text { in }\end{array}$ & $\begin{array}{l}n \\
\infty \\
\infty \\
n\end{array}$ \\
\hline 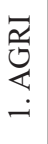 & $\stackrel{m}{8}$ & 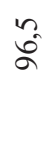 & $\vec{a}$ & $\hat{\infty}$ & $\begin{array}{l}\infty \\
\infty \\
\infty\end{array}$ & $\underset{\infty}{\infty}$ & $\begin{array}{l}0 \\
\stackrel{2}{N}\end{array}$ & $\vec{r}$ & $\stackrel{\circ}{\stackrel{r}{ }}$ & $\stackrel{0}{\circ}$ & 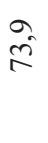 & $\underset{⿱}{\stackrel{\Delta}{N}}$ & 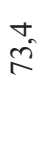 & 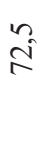 & 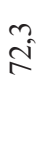 & $\frac{\infty}{i}$ \\
\hline 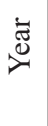 & ڤి & ষ্ণ & 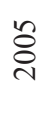 & ஜ̊ & 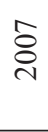 & $\stackrel{\infty}{\stackrel{\circ}{\circ}}$ & ஓे & $\stackrel{\circ}{\stackrel{ }{ }}$ & $\overrightarrow{\vec{\sim}}$ & $\frac{\sim}{\stackrel{\sim}{\sim}}$ & $\frac{m}{\stackrel{d}{d}}$ & $\underset{\sim}{\stackrel{D}{\sigma}}$ & $\frac{n}{\stackrel{d}{r}}$ & $\stackrel{0}{\stackrel{0}{0}}$ & $\stackrel{\curvearrowright}{\stackrel{\sim}{\sigma}}$ & $\frac{\infty}{\stackrel{\sim}{\sim}}$ \\
\hline
\end{tabular}




\begin{tabular}{|c|c|c|c|c|c|c|c|c|c|c|c|c|c|c|c|c|}
\hline$\underset{Ð}{\mathbb{S}}$ & $\begin{array}{l}n \\
\hat{n} \\
\hat{n}\end{array}$ & $\begin{array}{l}\stackrel{n}{8} \\
\stackrel{\circ}{-}\end{array}$ & $\begin{array}{l}\hat{\sigma} \\
\hat{\tilde{O}} \\
\hat{n}\end{array}$ & $\begin{array}{l}\hat{n} \\
\frac{\infty}{\infty}\end{array}$ & $\begin{array}{c}\vec{n} \\
\stackrel{n}{N} \\
\frac{n}{v}\end{array}$ & 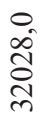 & $\begin{array}{l}\forall \\
\tilde{n}^{2} \\
\tilde{n} \\
\tilde{n}\end{array}$ & $\begin{array}{l}\stackrel{O}{N} \\
\stackrel{\sim}{\Xi} \\
\Xi\end{array}$ & 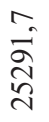 & $\begin{array}{l}0 \\
\curvearrowleft \\
\infty \\
\infty \\
\stackrel{\sim}{\sim}\end{array}$ & 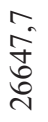 & $\begin{array}{l}\hat{2} \\
\stackrel{\infty}{\curvearrowright} \\
\stackrel{n}{\sim}\end{array}$ & 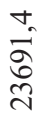 & $\underset{\text { ন }}{\stackrel{a}{J}}$ & 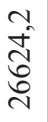 & 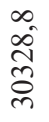 \\
\hline $\begin{array}{l}\tilde{2} \\
0 \\
0 \\
0\end{array}$ & $\begin{array}{l}n \\
\stackrel{N}{N}\end{array}$ & $\begin{array}{l}\infty \\
\dot{n} \\
n\end{array}$ & $\begin{array}{l}\stackrel{m}{+} \\
\stackrel{m}{+}\end{array}$ & $\frac{n}{n}$ & $\underset{\infty}{\stackrel{\infty}{\infty}}$ & $\frac{0}{a}$ & $\overrightarrow{\vec{\sigma}}$ & $\begin{array}{l}\stackrel{0}{2} \\
\stackrel{\infty}{n}\end{array}$ & $\stackrel{n}{\infty}$ & $\begin{array}{l}\infty \\
\infty \\
\stackrel{+}{\sim}\end{array}$ & $\stackrel{\infty}{2}$ & $\begin{array}{l}\infty \\
\dot{\mathbb{\infty}}\end{array}$ & $\begin{array}{l}0 \\
\infty \\
\delta\end{array}$ & ते & $\begin{array}{l}\hat{\sigma}_{0} \\
\frac{\infty}{1}\end{array}$ & $\hat{\infty}$ \\
\hline $\begin{array}{l}\text { 允 } \\
\text { 完 } \\
\text { a }\end{array}$ & $\begin{array}{l}\nabla_{0} \\
\delta \\
\delta\end{array}$ & $\begin{array}{l}\overrightarrow{0} \\
8 \\
\text { ¿े }\end{array}$ & $\begin{array}{l}\overrightarrow{ \pm} \\
\stackrel{\Delta}{\Delta}\end{array}$ & 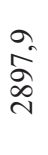 & 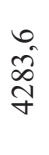 & 年 & $\frac{0}{\dot{8}}$ & $\begin{array}{l}\text { n} \\
\stackrel{2}{n} \\
\stackrel{n}{n}\end{array}$ & $\begin{array}{l}\vec{n} \\
\stackrel{\infty}{m}\end{array}$ & $\begin{array}{l}\infty \\
\hat{i} \\
\stackrel{n}{n} \\
\hat{m}\end{array}$ & $\begin{array}{l}\vec{o} \\
\text { ô }\end{array}$ & $\begin{array}{l}\stackrel{+}{r} \\
\stackrel{\sim}{\sim}\end{array}$ & 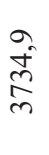 & $\begin{array}{l}\stackrel{n}{0} \\
\frac{0}{2}\end{array}$ & $\begin{array}{l}\stackrel{a}{ } \\
\tilde{b} \\
\stackrel{y}{f}\end{array}$ & $\begin{array}{l}\vec{a} \\
\frac{\hat{\sigma}}{\sigma}\end{array}$ \\
\hline $\begin{array}{l}\underset{1}{ٍ} \\
\underset{\infty}{\infty} \\
\infty \\
\infty\end{array}$ & $\begin{array}{l}0 \\
\infty^{n} \\
i n\end{array}$ & 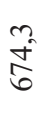 & $\stackrel{+}{\stackrel{\sigma}{\sigma}}$ & $\begin{array}{l}\stackrel{+}{8} \\
\stackrel{\Xi}{=}\end{array}$ & $\begin{array}{l}\frac{n}{6} \\
\stackrel{0}{n}\end{array}$ & $\begin{array}{l}\stackrel{+}{\sim} \\
\underset{\sim}{\sim}\end{array}$ & $\begin{array}{l}0 \\
\infty \\
2 \\
0\end{array}$ & \begin{tabular}{l}
$n$ \\
\multirow{n}{*}{} \\
$n$
\end{tabular} & $\begin{array}{l}\stackrel{0}{2} \\
\stackrel{n}{\varrho}\end{array}$ & $\begin{array}{l}\dot{J}^{2} \\
\stackrel{\Delta}{\infty}\end{array}$ & $\begin{array}{l}n \\
\wp \\
\infty \\
2\end{array}$ & 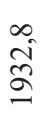 & $\begin{array}{l}\infty \\
\stackrel{\infty}{\Sigma} \\
\underline{=}\end{array}$ & $\begin{array}{l}0 \\
\infty \\
+\infty \\
\infty\end{array}$ & $\begin{array}{l}\infty \\
0 \\
\dot{0} \\
\stackrel{d}{0}\end{array}$ & $\begin{array}{l}\vec{\infty} \\
\infty \\
\approx\end{array}$ \\
\hline 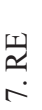 & $\overrightarrow{\tilde{a}}$ & 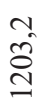 & 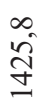 & $\begin{array}{l}\stackrel{m}{\infty} \\
\stackrel{\infty}{\sim}\end{array}$ & $\hat{\sigma}_{\hat{n}}$ & $\begin{array}{l}n \\
\infty \\
\infty \\
\infty\end{array}$ & $\begin{array}{l}\overrightarrow{0} \\
\text { dे }\end{array}$ & $\begin{array}{l}\hat{v} \\
\frac{\hat{v}}{v}\end{array}$ & $\begin{array}{l}0 \\
\stackrel{8}{8} \\
\stackrel{\infty}{N}\end{array}$ & 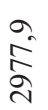 & $\begin{array}{l}\stackrel{\sim}{1} \\
\dot{\infty} \\
\text { m}\end{array}$ & $\begin{array}{l}\hat{\theta} \\
\dot{d} \\
\dot{d}\end{array}$ & 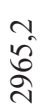 & $\begin{array}{l}\dot{t}_{n} \\
\text { ñ } \\
\text { ñ }\end{array}$ & $\overrightarrow{\vec{N}}$ & $\begin{array}{l}\text { ते } \\
\text { ते }\end{array}$ \\
\hline$\frac{\text { Z }}{\text { 品 }}$ & $\frac{\hat{n}}{n}$ & $\begin{array}{l}\hat{\infty} \\
\infty \\
\infty\end{array}$ & $\hat{8}$ & $\frac{N}{\infty}$ & 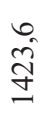 & $\begin{array}{l}0 \\
\stackrel{2}{2} \\
\stackrel{2}{=}\end{array}$ & $\begin{array}{l}\infty \\
\underset{D}{ \pm}\end{array}$ & $\hat{n}$ & $\stackrel{n}{a}$ & $\begin{array}{l}n \\
\int_{0} \\
\text { } \\
0\end{array}$ & $\begin{array}{l}0 \\
\ddot{0} \\
0 \\
0\end{array}$ & 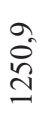 & $\begin{array}{l}\stackrel{n}{\cong} \\
\Xi\end{array}$ & $\begin{array}{l}n \\
\tilde{n} \\
=\end{array}$ & $\begin{array}{l}0 \\
\text { से } \\
\text { है }\end{array}$ & $\begin{array}{l}n \\
\hat{0} \\
=\end{array}$ \\
\hline $\begin{array}{l}0 \\
\text { ㄴ. } \\
\text { Z } \\
\text { in }\end{array}$ & $\begin{array}{l}0 \\
\stackrel{0}{0} \\
i\end{array}$ & $\tilde{n}^{n}$ & $\begin{array}{l}0 \\
i \\
\infty \\
0\end{array}$ & $\underset{⿱}{\stackrel{\sim}{N}}$ & $\overrightarrow{\tilde{a}}$ & $\hat{\widetilde{A}}$ & $\begin{array}{l}\hat{\sigma} \\
\text { ลे }\end{array}$ & $\begin{array}{l}\infty \\
\infty \\
\infty \\
\infty\end{array}$ & $\hat{\hat{a}}$ & $\begin{array}{l}\infty \\
\dot{0} \\
\infty \\
0\end{array}$ & $\begin{array}{l}\bar{\Omega} \\
\text { ڤ }\end{array}$ & $\begin{array}{l}0 \\
\text { ¿ิ } \\
\text { ป̂. }\end{array}$ & $\hat{\tilde{\infty}}$ & $\begin{array}{l}0 \\
\ddot{0} \\
\equiv\end{array}$ & 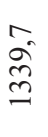 & $\begin{array}{l}\overrightarrow{0} \\
\tilde{n} \\
0\end{array}$ \\
\hline 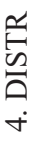 & $\begin{array}{l}\vec{\infty} \\
\stackrel{0}{8} \\
\text { d }\end{array}$ & 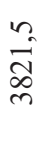 & 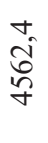 & $\begin{array}{l}+ \\
\underset{n}{n} \\
\hat{n}\end{array}$ & 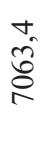 & $\begin{array}{l}n \\
\stackrel{n}{0} \\
\infty \\
\infty\end{array}$ & 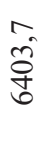 & $\begin{array}{l}n \\
\infty \\
\infty \\
\infty \\
n\end{array}$ & 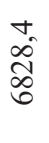 & $\begin{array}{l}\infty \\
\infty \\
n \\
\tilde{b}\end{array}$ & $\begin{array}{l}n \\
\infty \\
2 \\
\hat{\sigma}\end{array}$ & $\begin{array}{l}0 \\
\text { ปิ } \\
\text { ָิ }\end{array}$ & 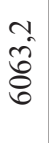 & $\frac{\stackrel{m}{\sigma}}{\sigma}$ & $\begin{array}{l}\vec{\infty} \\
\dot{0} \\
\dot{0}\end{array}$ & 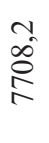 \\
\hline 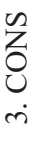 & $\begin{array}{l}\stackrel{0}{\sim} \\
\text { J̃ }\end{array}$ & $\begin{array}{l}m \\
\infty \\
\infty \\
\infty\end{array}$ & $\stackrel{n}{\stackrel{n}{0}}$ & $\stackrel{\infty}{\stackrel{\infty}{\sigma}}$ & $\begin{array}{l}\text { ô } \\
\stackrel{\delta}{v}\end{array}$ & $\stackrel{n}{\tilde{n}}$ & $\begin{array}{l}0 \\
\stackrel{6}{ } \\
\sim \\
\infty\end{array}$ & 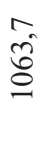 & $\begin{array}{l}\text { त̂ } \\
\text { ठ̊ } \\
\end{array}$ & $\begin{array}{l}\forall \\
\infty \\
\stackrel{0}{\curvearrowleft} \\
\end{array}$ & $\begin{array}{l}\stackrel{0}{n} \\
\stackrel{n}{=}\end{array}$ & $\begin{array}{l}0 \\
\hat{n} \\
\infty \\
\infty\end{array}$ & $\begin{array}{l}\stackrel{n}{n} \\
\hat{n} \\
n\end{array}$ & $\stackrel{n}{2}$ & $\underset{\square}{\stackrel{\Xi}{0}}$ & $\frac{\vec{a}}{\stackrel{v}{v}}$ \\
\hline 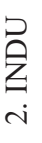 & బू & 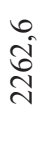 & $\begin{array}{l}\stackrel{n}{\sim} \\
\stackrel{\sim}{\sim}\end{array}$ & $\begin{array}{l}\overrightarrow{\mathbb{d}} \\
\infty \\
\stackrel{\sim}{N}\end{array}$ & $\begin{array}{l}\text { No } \\
\infty \\
\tilde{m}\end{array}$ & $\begin{array}{l}\overrightarrow{\tilde{y}} \\
\stackrel{y}{f}\end{array}$ & $\begin{array}{l}\hat{m} \\
\infty \\
0 \\
0\end{array}$ & $\underset{\substack{\infty \\
\infty}}{\stackrel{n}{\infty}}$ & $\begin{array}{l}\hat{\sigma} \\
\stackrel{f}{f}\end{array}$ & $\begin{array}{l}n \\
\infty \\
\infty \\
\stackrel{\infty}{f}\end{array}$ & $\frac{\sigma}{\stackrel{\Im}{f}}$ & $\underset{\stackrel{\infty}{f}}{\stackrel{\infty}{f}}$ & 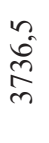 & 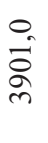 & $\begin{array}{l}\stackrel{g}{ } \\
\text { मे } \\
\ddot{f}\end{array}$ & $\begin{array}{l}0 \\
\infty \\
\infty \\
\infty \\
\infty\end{array}$ \\
\hline 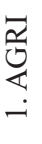 & 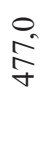 & $\begin{array}{l}\infty \\
0_{0}^{\infty} \\
\sigma_{0}^{\prime}\end{array}$ & $\begin{array}{l}\stackrel{+}{*} \\
\text { J }\end{array}$ & ڤ̊̊̊ & $\begin{array}{l}\vec{\infty} \\
\stackrel{0}{0} \\
\widetilde{O}\end{array}$ & $\begin{array}{l}\infty \\
\hat{n} \\
\tilde{0}\end{array}$ & $\begin{array}{l}0 \\
\infty \\
\infty\end{array}$ & $\begin{array}{l}\forall_{0} \\
\delta \\
\sigma\end{array}$ & $\stackrel{a}{a}$ & 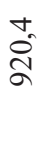 & $\begin{array}{l}\text { ñ } \\
\text { â }\end{array}$ & $\overrightarrow{\widetilde{f}}$ & 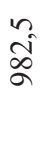 & $\underset{\infty}{\infty}$ & \begin{tabular}{l}
0 \\
\multirow{N}{a}{}
\end{tabular} & 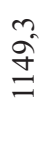 \\
\hline 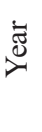 & ণ্ণి & ষ্ণ & ஜ̊ & ஜ̊ & 홍 & $\stackrel{\infty}{8}$ & ஓे & $\stackrel{\circ}{\stackrel{\sim}{\circ}}$ & $\overrightarrow{\vec{c}}$ & $\frac{\sim}{\stackrel{\sim}{\sim}}$ & $\stackrel{m}{\stackrel{\sim}{\sim}}$ & $\stackrel{ \pm}{\underset{d}{d}}$ & $\frac{n}{i}$ & $\stackrel{0}{\stackrel{0}{d}}$ & $\stackrel{ }{\stackrel{ }{2}}$ & $\stackrel{\infty}{\stackrel{\infty}{\sigma}}$ \\
\hline
\end{tabular}




\begin{tabular}{|c|c|c|c|c|c|c|c|c|c|c|c|c|c|c|c|c|}
\hline 岂 & $\begin{array}{l}n \\
\infty \\
2 \\
\curvearrowleft\end{array}$ & $\begin{array}{l}0 \\
\text { రి } \\
0\end{array}$ & ని & 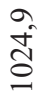 & تే & $\vec{n}$ & $\hat{\overbrace{}}$ & $\stackrel{n}{\stackrel{n}{\infty}}$ & 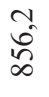 & $\begin{array}{l}0 \\
\infty \\
\infty \\
\infty\end{array}$ & $\begin{array}{l}0 \\
\infty \\
\infty \\
\infty\end{array}$ & $\begin{array}{l}0 \\
0 \\
\infty\end{array}$ & $\begin{array}{l}0 \\
\infty \\
\infty\end{array}$ & $\begin{array}{l}\text { m. } \\
\infty \\
\infty \\
\infty\end{array}$ & $\begin{array}{l}0 \\
\infty \\
\infty \\
\infty\end{array}$ & 요 \\
\hline $\begin{array}{l}0 \\
0 \\
0\end{array}$ & $\begin{array}{l}\infty \\
\dot{m}\end{array}$ & nో & $\stackrel{\infty}{\stackrel{0}{f}}$ & $\stackrel{n}{\sim}$ & $\stackrel{\infty}{\mathscr{\gamma}}$ & ఠ̊ & ? & $\underset{\infty}{\infty}$ & ñ & $\vec{m}$ & $\vec{f}$ & m. & $\stackrel{\vartheta}{q}$ & $\hat{\vartheta}$ & $\vec{f}$ & $\stackrel{+}{\stackrel{+}{+}}$ \\
\hline 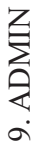 & $\stackrel{a}{\curvearrowright}$ & $\stackrel{\sigma^{\circ}}{\hat{\sigma}}$ & ̊̊. & $\stackrel{+}{\stackrel{+}{0}}$ & ণֶ. & ఠ̊ & $\vec{a}$ & $\stackrel{\substack{\infty \\
=}}{=}$ & $\begin{array}{l}\nabla_{0} \\
\stackrel{\infty}{\infty}\end{array}$ & \begin{tabular}{l}
0 \\
\multirow{\infty}{*}{}
\end{tabular} & $\stackrel{\infty}{\infty}$ & $\stackrel{\Omega}{\Omega}$ & $\stackrel{\infty}{\infty}$ & $\frac{\sigma}{\infty}$ & $\begin{array}{l}0 \\
\dot{0} \\
\infty\end{array}$ & $\begin{array}{l}\nabla_{0} \\
\mathbb{D}_{0}\end{array}$ \\
\hline $\begin{array}{l}\underset{1}{Z} \\
\underset{\sim}{\operatorname{m}} \\
\infty \\
\infty\end{array}$ & ิㅏㅁ & $\begin{array}{l}0 \\
\stackrel{\infty}{+}\end{array}$ & $\stackrel{\partial}{\sigma}$ & in & $\begin{array}{l}0 \\
\text { ह0 }\end{array}$ & $\tilde{6}$ & $\begin{array}{l}n \\
\infty \\
n\end{array}$ & $\begin{array}{l}0 \\
n \\
n\end{array}$ & $\begin{array}{l}0 \\
\infty \\
\infty \\
n\end{array}$ & $\stackrel{n}{2}$ & o. & $\begin{array}{l}0 \\
i\end{array}$ & 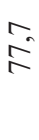 & $\stackrel{n}{2}$ & ন্ & $\overbrace{\infty}^{n}$ \\
\hline$\frac{\sqrt{2}}{\sim}$ & $\stackrel{m}{\infty}$ & $\tilde{a}$ & $\stackrel{m}{2}$ & $\stackrel{\hat{\jmath}}{\hat{\jmath}}$ & $\stackrel{n}{\sim}$ & $\begin{array}{l}0 \\
\dot{J}\end{array}$ & $\stackrel{m}{\sim}$ & حૂ & 2 & $\stackrel{\overbrace{}}{\tilde{N}}$ & 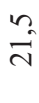 & $\begin{array}{l}\text { ․ } \\
\text { ปิ }\end{array}$ & ๙ู & $\overrightarrow{\tilde{N}}$ & $\frac{a_{n}}{\lambda}$ & $\stackrel{\nabla}{\stackrel{\nabla}{d}}$ \\
\hline$\frac{Z}{\dot{Z}}$ & $\overrightarrow{6}$ & N & $\stackrel{\infty}{\infty}$ & $\stackrel{\infty}{\infty}$ & 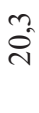 & $\stackrel{\vec{N}}{\vec{N}}$ & $\hat{\sigma}$ & 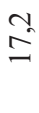 & $\stackrel{\sigma_{n}}{\stackrel{\Xi}{2}}$ & $\hat{\sigma}$ & $\overrightarrow{6}$ & $\begin{array}{l}0 \\
\cong\end{array}$ & $\hat{\imath}$ & no & $\underset{\sigma}{+}$ & $\begin{array}{l}\infty \\
n\end{array}$ \\
\hline $\begin{array}{l}0 \\
\text { 岌 } \\
\text { 它 }\end{array}$ & $\begin{array}{l}0 \\
\stackrel{\sim}{ }\end{array}$ & $\begin{array}{l}\infty \\
\underset{\sim}{\sim}\end{array}$ & $\hat{a}$ & $\vec{\infty}$ & $\stackrel{n}{\sim}$ & ָ̃ & $\begin{array}{l}0 \\
2\end{array}$ & $\stackrel{a}{a}$ & $\frac{n}{N}$ & $\underset{\sim}{\stackrel{\infty}{\sim}}$ & $\vec{d}$ & $\hat{\vartheta}$ & $\stackrel{\sqrt{\infty}}{\sim}$ & $\hat{\ominus}$ & ñ & $\begin{array}{l}\nabla_{0} \\
\stackrel{n}{n}\end{array}$ \\
\hline $\begin{array}{l}\stackrel{\alpha}{\omega} \\
\stackrel{\Omega}{\rho} \\
\dot{\nabla}\end{array}$ & $\underset{\sim}{\stackrel{\sim}{\sim}}$ & å & $\frac{0}{N}$ & 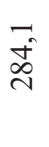 & مू & $\begin{array}{l}0 \\
\text { ㅇ } \\
\delta\end{array}$ & బิ & \begin{tabular}{l}
0 \\
\multirow{2}{*}{} \\
$\stackrel{2}{1}$
\end{tabular} & $\overrightarrow{\stackrel{n}{\sim}}$ & ๙n & $\stackrel{n}{\stackrel{n}{\sim}}$ & $\vec{J}$ & $\underset{\sim}{\stackrel{\infty}{\sim}}$ & $\stackrel{n}{\stackrel{n}{\sim}}$ & 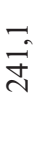 & $\stackrel{\vec{\sim}}{\stackrel{\sim}{\sim}}$ \\
\hline 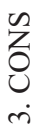 & $\begin{array}{l}\nabla_{0} \\
\mathbb{J}^{\prime}\end{array}$ & $\begin{array}{l}0 \\
\hat{\sigma}\end{array}$ & $\stackrel{\sigma^{\prime}}{\hat{b}}$ & $\overrightarrow{\hat{a}}$ & $\stackrel{\substack{\infty \\
0}}{\infty}$ & $\stackrel{1}{\infty}$ & $\stackrel{\infty}{N}$ & $\begin{array}{l}\nabla^{\prime} \\
\infty \\
\infty\end{array}$ & $\vec{\sigma}$ & $\begin{array}{l}\infty \\
\stackrel{0}{0}\end{array}$ & $\begin{array}{l}0 \\
\mathbb{J}^{\circ}\end{array}$ & $\hat{\theta}$ & $\tilde{6}$ & గn & $\tilde{\sigma}$ & ติ \\
\hline 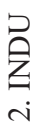 & 2 & $\begin{array}{l}\infty \\
\infty \\
\infty\end{array}$ & $\begin{array}{c}0 \\
\infty\end{array}$ & º & $\stackrel{n}{\infty}$ & $\stackrel{n}{2}$ & $\stackrel{\Xi}{\Xi}$ & $\begin{array}{l}\nabla_{0} \\
\stackrel{\infty}{\simeq}\end{array}$ & $\stackrel{\sim}{\check{I}}$ & 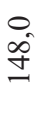 & 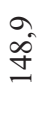 & $\stackrel{\nabla_{n}}{\Xi}$ & $\begin{array}{l}0 \\
\stackrel{f}{ \pm}\end{array}$ & $\begin{array}{l}0 \\
\pm \\
\pm\end{array}$ & $\stackrel{\varrho}{\text { f }}$ & $\stackrel{0}{ \pm}$ \\
\hline$\underset{\sim}{\stackrel{\nabla}{\sim}}$ & $\stackrel{a}{\stackrel{a}{d}}$ & $\stackrel{+}{\sigma^{2}}$ & $\stackrel{+}{\text { ๙ }}$ & $\stackrel{\hat{n}}{0}$ & $\begin{array}{l}0 \\
\infty \\
\infty\end{array}$ & $\hat{\curvearrowright}$ & $\overbrace{}^{n}$ & గ్ర & $\begin{array}{l}0 \\
\infty \\
0\end{array}$ & $\underset{0}{\infty}$ & $\underset{\sigma}{\infty}$ & బิ & $\hat{\sigma}$ & $\frac{\sigma_{n}}{\sigma}$ & బิ & $\stackrel{2}{6}$ \\
\hline$\stackrel{\Xi}{\bar{Z}}$ & હ̊̊ి & ঠ্ণ & ঠి & 응 & 용 & 串 & ஓి & $\stackrel{\circ}{\stackrel{0}{0}}$ & $\bar{\Xi}$ & $\frac{\sim}{\curvearrowright}$ & $\stackrel{m}{\frac{m}{\sigma}}$ & $\stackrel{\nabla}{\stackrel{\nabla}{\circ}}$ & $\frac{n}{\stackrel{n}{(}}$ & $\frac{0}{0}$ & $\frac{\bar{\delta}}{\mathrm{N}}$ & $\frac{\infty}{\stackrel{\sim}{\sigma}}$ \\
\hline
\end{tabular}




\begin{tabular}{|c|c|c|c|c|c|c|c|c|c|c|c|c|c|c|c|c|}
\hline$\underset{Ð}{\longleftarrow}$ & \begin{tabular}{l}
$\tilde{a}$ \\
\multirow{\infty}{0}{} \\
0
\end{tabular} & $\begin{array}{l}+ \\
\infty \\
\infty \\
\stackrel{\infty}{0} \\
\stackrel{\sim}{0}\end{array}$ & $\begin{array}{l}\text { ㄱ. } \\
\stackrel{0}{0} \\
\overparen{\lambda}\end{array}$ & $\begin{array}{l}0 \\
\stackrel{0}{0} \\
\stackrel{0}{N} \\
\text { N }\end{array}$ & 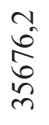 & $\begin{array}{l}\text { ⿵̃丶 } \\
\text { ๙े }\end{array}$ & $\begin{array}{l}\underset{N}{N} \\
\stackrel{N}{n}\end{array}$ & 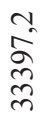 & $\begin{array}{l}\hat{\infty} \\
\infty \\
\stackrel{\infty}{\infty}\end{array}$ & $\underset{\substack{\hat{N} \\
\text { N }}}{\stackrel{n}{N}}$ & $\begin{array}{l}\vec{\infty} \\
\dot{\infty} \\
\stackrel{\overbrace{}}{f}\end{array}$ & 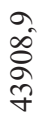 & $\begin{array}{c}\infty \\
\text { n} \\
\text { n}\end{array}$ & $\begin{array}{l}r \\
\infty \\
0 \\
0 \\
\infty \\
\infty \\
\infty\end{array}$ & $\underset{\stackrel{\Im}{N}}{\stackrel{\Im}{\sim}}$ & $\begin{array}{l}\stackrel{\partial}{ } \\
\infty \\
\infty^{2} \\
\stackrel{+}{\forall}\end{array}$ \\
\hline $\begin{array}{l}\tilde{0} \\
0 \\
0\end{array}$ & $\begin{array}{l}\infty \\
\text { o } \\
\stackrel{+}{+}\end{array}$ & $\frac{r}{\frac{n}{f}}$ & $\begin{array}{l}0 \\
\hat{n} \\
n\end{array}$ & ले & $\begin{array}{l}0 \\
\underset{\mathbb{J}}{ }\end{array}$ & $\begin{array}{l}0 \\
\stackrel{2}{\nabla}\end{array}$ & $\begin{array}{l}0 \\
\hat{a} \\
\hat{\sigma}\end{array}$ & ڤ్రి & $\begin{array}{l}J_{0} \\
\text { İ }\end{array}$ & $\begin{array}{l}\dot{J}_{0} \\
\vec{g}\end{array}$ & $\frac{\circ}{\infty}$ & 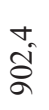 & $\frac{\partial}{\infty}$ & 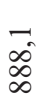 & $\begin{array}{l}\infty \\
\stackrel{0}{0} \\
2\end{array}$ & 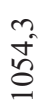 \\
\hline 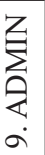 & 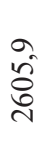 & $\begin{array}{l}\vec{\sigma}_{0} \\
\stackrel{\infty}{\infty}\end{array}$ & $\begin{array}{l}n \\
n \\
n \\
n\end{array}$ & $\begin{array}{l}\vec{\AA} \\
\text { ๙ે }\end{array}$ & $\begin{array}{l}\infty \\
\stackrel{\infty}{\infty} \\
\stackrel{+}{+}\end{array}$ & $\begin{array}{c}\stackrel{0}{N} \\
\underset{\text { V }}{N}\end{array}$ & $\begin{array}{l}\hat{0} \\
\hat{\Omega} \\
\text { हn }\end{array}$ & $\begin{array}{l}\dot{\sigma}_{n} \\
\underset{n}{\sim}\end{array}$ & $\begin{array}{l}\text { ֶీ } \\
\text { } \\
i\end{array}$ & $\begin{array}{l}\stackrel{n}{+} \\
\underset{n}{+}\end{array}$ & $\begin{array}{l}\infty \\
\infty \\
\infty \\
\infty \\
n\end{array}$ & $\overrightarrow{\tilde{n}}$ & 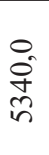 & $\begin{array}{l}+ \\
\dot{D} \\
i \\
n\end{array}$ & $\begin{array}{l}\infty \\
\infty \\
\stackrel{\infty}{8}\end{array}$ & $\begin{array}{l}\text { N } \\
\text { in } \\
\infty \\
0\end{array}$ \\
\hline $\begin{array}{l}\underset{1}{\mid} \\
\underset{\infty}{\infty} \\
\infty \\
\infty\end{array}$ & $\begin{array}{l}n \\
\text { â }\end{array}$ & $\begin{array}{l}\hat{~} \\
\text { ूे }\end{array}$ & $\begin{array}{l}0 \\
\stackrel{I}{I} \\
\end{array}$ & $\begin{array}{l}0 \\
\hat{m} \\
\stackrel{m}{ \pm}\end{array}$ & 莽 & $\begin{array}{l}n \\
\infty \\
\stackrel{\infty}{\sim}\end{array}$ & $\begin{array}{l}\frac{0}{0} \\
\frac{\vec{v}}{v}\end{array}$ & 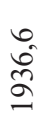 & 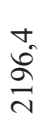 & 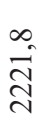 & $\begin{array}{l}\vec{\sigma} \\
\vec{n}\end{array}$ & $\begin{array}{l}\vec{a} \\
\vec{d} \\
\stackrel{d}{0}\end{array}$ & $\begin{array}{l}\infty \\
\stackrel{\infty}{0} \\
\stackrel{\overbrace{}}{\sim}\end{array}$ & 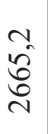 & î̀ & $\begin{array}{l}\stackrel{0}{0} \\
\text { \&े } \\
\text { m. }\end{array}$ \\
\hline $\begin{array}{l}\frac{1}{\sim} \\
\stackrel{r}{r}\end{array}$ & $\begin{array}{l}0 \\
\text { ஸे } \\
\text { ஸे }\end{array}$ & $\begin{array}{l}0 \\
\stackrel{0}{0} \\
\text { I }\end{array}$ & $\vec{n}$ & $\begin{array}{l}\hat{\sigma} \\
\text { શે } \\
\text { In }\end{array}$ & $\begin{array}{l}O \\
\stackrel{+}{+} \\
\stackrel{d}{+}\end{array}$ & 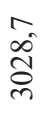 & $\hat{m}_{\hat{n}}^{\hat{n}}$ & 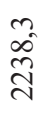 & 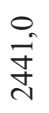 & $\begin{array}{l}\infty \\
\hat{D} \\
\ddot{d}\end{array}$ & 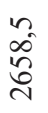 & $\begin{array}{r}\hat{a} \\
\stackrel{+}{\sim}\end{array}$ & $\begin{array}{l}\hat{n} \\
\text { in } \\
\text { in }\end{array}$ & $\begin{array}{l}\stackrel{n}{-} \\
\dot{\infty} \\
\stackrel{d}{v}\end{array}$ & $\begin{array}{l}0 \\
0 \\
+ \\
+ \\
\text { d }\end{array}$ & 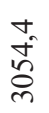 \\
\hline $\begin{array}{l}\underset{I}{Z} \\
\stackrel{0}{0}\end{array}$ & $\begin{array}{l}\infty \\
\text { तิ } \\
\text { n }\end{array}$ & $\frac{0}{\hat{a}}$ & $\begin{array}{l}0 \\
\vec{i} \\
i n\end{array}$ & $\stackrel{\substack{\infty \\
\infty}}{\stackrel{\infty}{N}}$ & 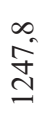 & 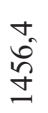 & $\frac{\vec{b}_{\infty}}{\infty}$ & $\begin{array}{l}g \\
\dot{J} \\
\text { Jे }\end{array}$ & $\begin{array}{l}\vec{n} \\
\dot{0}\end{array}$ & ஸ̂ & $\frac{\vec{c}}{a}$ & $\frac{n}{\infty}$ & $\stackrel{\substack{\infty \\
\infty}}{\infty}$ & $\underset{\infty}{\stackrel{f}{f}}$ & $\stackrel{n}{\infty}$ & $\begin{array}{l}0 \\
\tilde{8} \\
0\end{array}$ \\
\hline $\begin{array}{l}0 \\
\text { ○ } \\
\text { Zn } \\
\text { i }\end{array}$ & $\begin{array}{l}\infty \\
\stackrel{\infty}{+} \\
\infty\end{array}$ & $\frac{a}{8}$ & $\begin{array}{l}\nabla^{2} \\
\infty \\
\curvearrowleft\end{array}$ & $\begin{array}{l}\text { m } \\
\infty \\
0 \\
0\end{array}$ & $\begin{array}{l}n \\
\tilde{n} \\
n\end{array}$ & $\begin{array}{l}\infty \\
\stackrel{N}{J} \\
\stackrel{1}{J}\end{array}$ & $\begin{array}{l}n \\
\text { तิ } \\
\text { }\end{array}$ & 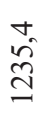 & $\begin{array}{l}0 \\
\stackrel{1}{\beth} \\
\text { I }\end{array}$ & $\stackrel{n}{\hat{\sigma}}$ & $\begin{array}{l}0 \\
\stackrel{0}{0} \\
\stackrel{0}{n}\end{array}$ & 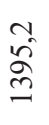 & 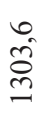 & $\begin{array}{l}\text { ป̂ } \\
\text { ஸे } \\
\text { I }\end{array}$ & $\begin{array}{l}\Delta_{n} \\
\stackrel{a}{n}\end{array}$ & $\begin{array}{l}n \\
\stackrel{n}{N}\end{array}$ \\
\hline 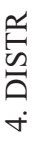 & \begin{tabular}{l}
$n$ \\
$\hat{\infty}$ \\
\multirow{\gamma}{*}{}
\end{tabular} & $\frac{\vec{F}}{\bar{n}}$ & $\frac{\nabla_{0}}{\vec{\delta}}$ & $\begin{array}{l}0 \\
\dot{d} \\
\stackrel{+}{+}\end{array}$ & $\begin{array}{l}0 \\
\hat{n} \\
2 \\
\alpha\end{array}$ & 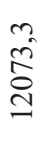 & $\begin{array}{l}+ \\
\stackrel{2}{2} \\
2\end{array}$ & $\begin{array}{l}\vec{v} \\
\tilde{y} \\
\tilde{0}\end{array}$ & $\begin{array}{l}\stackrel{0}{\sigma} \\
\stackrel{(}{\beth} \\
=\end{array}$ & $\begin{array}{l}\hat{\infty} \\
\infty \\
\approx \\
\cong\end{array}$ & $\begin{array}{l}m \\
\infty \\
0 \\
0 \\
=\end{array}$ & $\begin{array}{l}\hat{b} \\
\text { ठे } \\
\text { +े }\end{array}$ & $\begin{array}{l}\vec{a} \\
\underline{\sigma}\end{array}$ & $\begin{array}{l}\stackrel{0}{\cong} \\
\stackrel{\Xi}{\beth}\end{array}$ & $\begin{array}{l}\hat{0} \\
\infty \\
\ddot{n} \\
\cong\end{array}$ & $\begin{array}{l}n \\
8 \\
8 \\
\vdots \\
n\end{array}$ \\
\hline 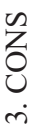 & $\stackrel{n}{\varrho}$ & $\begin{array}{l}0 \\
\stackrel{+}{\infty} \\
\stackrel{\infty}{ \pm}\end{array}$ & $\begin{array}{l}\text { Iे } \\
\text { Iे }\end{array}$ & $\begin{array}{l}\hat{\infty} \\
\hat{n} \\
\hat{n}\end{array}$ & $\begin{array}{l}\text { నू } \\
\text { ळे }\end{array}$ & $\frac{\stackrel{\rho}{~}}{\stackrel{\infty}{+}}$ & 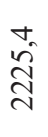 & 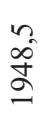 & $\begin{array}{l}0 \\
\text { in } \\
\text { ñ }\end{array}$ & 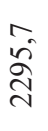 & $\begin{array}{l}\hat{\sigma} \\
\stackrel{0}{2} \\
\stackrel{2}{2}\end{array}$ & $\frac{\vec{\sigma}_{n}}{\underset{n}{n}}$ & 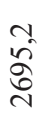 & $\begin{array}{l}\text { กे } \\
\text { ते } \\
\text { ते }\end{array}$ & $\begin{array}{l}\stackrel{\Re}{=} \\
\underset{\sim}{\sim}\end{array}$ & $\begin{array}{l}\infty \\
\text { on } \\
\text { dे }\end{array}$ \\
\hline 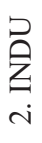 & $\begin{array}{l}\infty \\
\vec{b} \\
\dot{+}\end{array}$ & $\begin{array}{l}\text { के } \\
\stackrel{\infty}{ } \\
\hat{n}\end{array}$ & $\begin{array}{l}\overrightarrow{\hat{a}} \\
\stackrel{\infty}{n}\end{array}$ & $\begin{array}{l}0 \\
\text { को } \\
\text { dे }\end{array}$ & 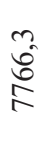 & $\begin{array}{l}\frac{n}{6} \\
\frac{\hat{\sigma}}{\sigma}\end{array}$ & $\frac{i}{n}$ & 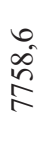 & $\begin{array}{l}\vec{n} \\
\text { đ̊ }\end{array}$ & $\frac{\vec{\pi}}{\vec{\sigma}}$ & $\begin{array}{l}\hat{y} \\
\infty \\
\infty \\
\infty\end{array}$ & $\begin{array}{l}0 \\
\text { in } \\
\stackrel{0}{0}\end{array}$ & $\begin{array}{l}\text { ֶ. } \\
\text { ñ } \\
\tilde{\infty}\end{array}$ & $\frac{\tilde{n}}{\tilde{n}}$ & $\begin{array}{l}n \\
\infty \\
0 \\
2 \\
n\end{array}$ & 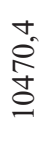 \\
\hline$\underset{\sim}{\stackrel{\vec{\alpha}}{\circlearrowright}}$ & $\hat{\infty}$ & $\vec{J}$ & $\begin{array}{l}\stackrel{m}{2} \\
\stackrel{m}{=}\end{array}$ & $\begin{array}{l}\overrightarrow{6} \\
\stackrel{0}{0} \\
=\end{array}$ & $\begin{array}{l}\stackrel{+}{\Omega} \\
\stackrel{\Omega}{n}\end{array}$ & $\vec{n}$ & 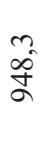 & $\begin{array}{l}n \\
\stackrel{n}{\Xi} \\
=\end{array}$ & $\stackrel{\infty}{=}$ & 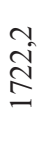 & $\begin{array}{l}0 \\
\frac{0}{0}\end{array}$ & $\begin{array}{l}0 \\
\text { îं } \\
\text { ర }\end{array}$ & $\begin{array}{l}\stackrel{\Im}{ \pm} \\
\stackrel{\sim}{ \pm}\end{array}$ & $\begin{array}{l}\tilde{2} \\
\underset{\sim}{\approx}\end{array}$ & $\begin{array}{l}\stackrel{+}{+} \\
\underset{+}{ \pm}\end{array}$ & 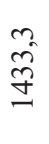 \\
\hline 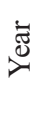 & ণ্ণి & ষ্ণ & 苂 & ஜ̊ & 홍 & $\stackrel{\infty}{\stackrel{0}{े}}$ & ஓे & $\stackrel{\circ}{\stackrel{\sim}{\circ}}$ & $\overrightarrow{\vec{c}}$ & $\frac{\sim}{\stackrel{\sim}{\sim}}$ & $\stackrel{m}{\stackrel{\sim}{\sim}}$ & $\underset{\sim}{\stackrel{\Xi}{\sigma}}$ & $\frac{n}{\stackrel{d}{r}}$ & $\stackrel{\bullet}{\stackrel{0}{\sigma}}$ & $\stackrel{ }{\vec{c}}$ & $\stackrel{\infty}{\stackrel{\infty}{\sigma}}$ \\
\hline
\end{tabular}




\begin{tabular}{|c|c|c|c|c|c|c|c|c|c|c|c|c|c|c|c|c|}
\hline 四 & $\stackrel{\sim}{\stackrel{\sim}{ \pm}}$ & $\stackrel{\overrightarrow{0}}{\stackrel{\Xi}{\Xi}}$ & 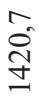 & $\frac{n}{\Xi}$ & $\vec{f}$ & $\begin{array}{l}\vec{b} \\
\stackrel{\sim}{ \pm}\end{array}$ & $\frac{n}{6}$ & 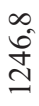 & กิ & 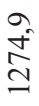 & $\stackrel{a}{a}$ & $\stackrel{\infty}{\cong}$ & $\begin{array}{r}\tilde{m} \\
\stackrel{m}{n}\end{array}$ & $\frac{\sqrt{6}}{\pi}$ & $\begin{array}{l}ت \\
\stackrel{\sim}{n} \\
\end{array}$ & $\begin{array}{l}\nabla_{0} \\
\infty \\
\stackrel{0}{0}\end{array}$ \\
\hline $\begin{array}{l}\mathscr{D} \\
0 \\
\dot{0}\end{array}$ & $\underset{\sim}{\stackrel{\gamma}{\sigma}}$ & $\frac{0}{n}$ & $\stackrel{+}{+}$ & $\dot{\nabla}$ & ๙ૂ & $\overrightarrow{\text { n }}$ & กิ & ఫิ & $\tilde{n}^{n}$ & กี & $\hat{n}$ & $\begin{array}{l}\nabla_{n} \\
\infty\end{array}$ & $\begin{array}{l}{ }^{\circ} \\
i n\end{array}$ & $\stackrel{2}{8}$ & $\frac{2}{6}$ & $\hat{\sigma}$ \\
\hline 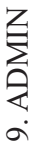 & $\frac{\infty}{m}$ & $\frac{\vec{a}}{m}$ & $\stackrel{m}{\sim}$ & $\begin{array}{l}0 \\
\dot{ \pm} \\
\text { ते }\end{array}$ & $\frac{n}{n}$ & $\frac{\vec{m}}{m}$ & & $\overrightarrow{\overbrace{}^{\circ}}$ & $\begin{array}{l}+ \\
\text { নे } \\
\text { নे }\end{array}$ & $\begin{array}{l}\dot{\sigma}^{2} \\
\stackrel{\sim}{ }\end{array}$ & ๙ิ & ลิ & 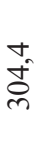 & $\frac{0}{m}$ & $\begin{array}{l}0 \\
\hat{\Omega}^{n} \\
\text { rn }\end{array}$ & $\begin{array}{l}0 \\
\hat{0} \\
0\end{array}$ \\
\hline $\begin{array}{l}Z \\
\underset{\infty}{\mid} \\
\underset{\infty}{0} \\
\infty\end{array}$ & $\hat{\overbrace{}}$ & $\stackrel{\circ}{g}$ & ڤิ & ণे & $\vec{b}$ & ন্ & $\frac{n}{\infty}$ & $\stackrel{n}{\infty}$ & $\frac{N}{\infty}$ & $\begin{array}{l}\infty \\
\infty \\
\infty\end{array}$ & $\begin{array}{l}0 \\
\text { a }\end{array}$ & $\stackrel{+}{2}$ & $\stackrel{\varrho}{8}$ & $\vec{g}$ & $\stackrel{0}{\equiv}$ & $\stackrel{n}{=}$ \\
\hline 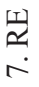 & ○. & $\underset{\infty}{\infty}$ & $\stackrel{\sigma_{0}}{\circ}$ & $\stackrel{0}{\equiv}$ & $\begin{array}{l}0 \\
a\end{array}$ & $\cong$ & $\stackrel{\nabla_{0}}{\Xi}$ & ป & $\widehat{\sim}$ & $\stackrel{m}{m}$ & $\stackrel{\infty}{n}$ & $\stackrel{\nabla}{\sim}$ & $\stackrel{n}{ \pm}$ & $\stackrel{n}{ \pm}$ & $\begin{array}{l}0 \\
\pm\end{array}$ & $\stackrel{\Xi}{ \pm}$ \\
\hline$\frac{Z}{6}$ & $\vec{\beth}$ & $\stackrel{g}{ \pm}$ & $\overbrace{}^{2}$ & $\begin{array}{l}\infty \\
n \\
n\end{array}$ & $\frac{\nabla_{0}}{\vec{N}}$ & $\stackrel{\infty}{-}$ & $\vec{\sim}$ & $\stackrel{n}{\overbrace{0}^{2}}$ & $\tilde{\approx}$ & $\stackrel{\infty}{\infty}$ & 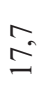 & $\stackrel{\forall}{\infty}$ & $\begin{array}{l}0 \\
\infty \\
-1\end{array}$ & $\begin{array}{l}0 \\
2\end{array}$ & $\vec{尺}$ & $\stackrel{2}{2}$ \\
\hline 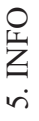 & $\begin{array}{l}\Xi \\
\pm\end{array}$ & 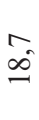 & $\stackrel{n}{2}$ & $\begin{array}{l}m \\
\infty\end{array}$ & $\stackrel{\infty}{i}$ & $\begin{array}{l}\dot{J}_{0} \\
\stackrel{\sim}{d}\end{array}$ & $\hat{\tilde{v}}$ & $\overrightarrow{\mathrm{d}}$ & $\stackrel{n}{n}$ & $\stackrel{\substack{\infty \\
\sim}}{\sim}$ & $\stackrel{\infty}{\stackrel{\sim}{\sim}}$ & ๙ิ & $\frac{N}{\sim}$ & $\widehat{\infty}$ & $\vec{\infty}$ & $\frac{n}{m}$ \\
\hline 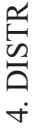 & $\underset{\sim}{\stackrel{\sim}{\sim}}$ & $\begin{array}{l}\text { N. } \\
\text { N }\end{array}$ & $\stackrel{\infty}{m}$ & $\begin{array}{l}+ \\
\stackrel{+}{+} \\
\text { r }\end{array}$ & $\frac{n}{n}$ & $\frac{\infty}{\infty}$ & $\stackrel{\tilde{N}^{\circ}}{\stackrel{\sim}{*}}$ & $\stackrel{\overrightarrow{+}}{\stackrel{+}{m}}$ & \begin{tabular}{l}
0 \\
0 \\
\multirow{0}{*}{}
\end{tabular} & $\begin{array}{r}\text { के } \\
\stackrel{\infty}{+}\end{array}$ & $\stackrel{a}{n}$ & 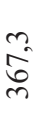 & $\begin{array}{l}\dot{ }^{\prime} \\
\infty \\
\stackrel{n}{n}\end{array}$ & $\vec{b}$ & 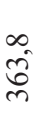 & $\hat{\sigma}$ \\
\hline 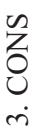 & $\overrightarrow{0}$ & $\begin{array}{l}0 \\
\text { ஸे }\end{array}$ & $\stackrel{\infty}{\stackrel{\infty}{N}}$ & $\begin{array}{l}\nabla_{n} \\
\stackrel{n}{n}\end{array}$ & สิ & $\begin{array}{l}\text { ஸे } \\
\stackrel{n}{n}\end{array}$ & $\stackrel{\check{m}}{\Xi}$ & $\begin{array}{l}\infty \\
\infty \\
\infty\end{array}$ & $\stackrel{0}{\infty}$ & $\stackrel{+}{\nabla_{0}}$ & $\vec{a}$ & $\bar{a}$ & \begin{tabular}{l}
$\infty$ \\
\multirow{0}{0}{}
\end{tabular} & $\begin{array}{l}\sigma_{0} \\
\stackrel{0}{0}\end{array}$ & $\hat{\infty}$ & $\stackrel{0}{8}$ \\
\hline 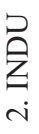 & $\frac{\nabla_{n}}{\text { নे }}$ & $\stackrel{\infty}{\stackrel{\infty}{\sim}}$ & ڤ̊ & $\stackrel{m}{\stackrel{n}{N}}$ & $\begin{array}{l}0 \\
\stackrel{2}{N}\end{array}$ & $\begin{array}{l}\text { ?. } \\
\stackrel{\infty}{N} \\
\text { N }\end{array}$ & $\begin{array}{l}\stackrel{\circ}{\circ} \\
\stackrel{+}{+}\end{array}$ & $\frac{\mathfrak{a}}{\sim}$ & $\begin{array}{l}0 \\
\text { N } \\
\text { N }\end{array}$ & 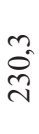 & $\begin{array}{l}n \\
\stackrel{n}{2} \\
\stackrel{2}{n}\end{array}$ & $\begin{array}{l}0 \\
\sigma^{\circ} \\
\text { N }\end{array}$ & $\begin{array}{l}\stackrel{0}{\Omega} \\
\stackrel{\text { సิ }}{ }\end{array}$ & $\begin{array}{l}n \\
\infty \\
\infty \\
\sim\end{array}$ & $\underset{\text { d }}{\stackrel{\sim}{d}}$ & 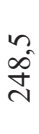 \\
\hline 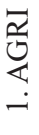 & $\frac{\infty}{\stackrel{n}{\sim}}$ & $\begin{array}{l}\stackrel{+}{\sim} \\
\stackrel{\overbrace{}}{N}\end{array}$ & 天े & $\stackrel{2}{2}$ & $\begin{array}{l}n \\
\text { \& } \\
\text { fo }\end{array}$ & $\begin{array}{l}0 \\
\pm \\
\Xi\end{array}$ & $\vec{\infty}$ & $\begin{array}{l}0 \\
\stackrel{0}{=}\end{array}$ & ช̊ & $\stackrel{0}{\text { ป }}$ & $\stackrel{0}{\infty}$ & $\hat{\overbrace{}}$ & $\stackrel{\tilde{\Omega}}{\hat{\jmath}}$ & $\begin{array}{l}\dot{\sigma}^{\circ} \\
\stackrel{\infty}{0}\end{array}$ & $\stackrel{2}{2}$ & 으 \\
\hline 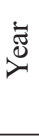 & હ̊̊ి & ঠ্ণ & $\stackrel{\overbrace{}}{\bigodot}$ & 응 & 용 & 串 & 용 & $\stackrel{\circ}{\stackrel{0}{\circ}}$ & $\bar{\Xi}$ & $\frac{\sim}{\curvearrowright}$ & $\stackrel{m}{\frac{m}{\sigma}}$ & $\frac{ \pm}{\stackrel{\Xi}{ঠ}}$ & $\frac{n}{\stackrel{n}{(}}$ & $\frac{0}{0}$ & $\stackrel{\bar{\sigma}}{\stackrel{\sim}{n}}$ & $\frac{\infty}{\stackrel{\sim}{\sigma}}$ \\
\hline
\end{tabular}




\begin{tabular}{|c|c|c|c|c|c|c|c|c|c|c|c|c|c|c|c|c|}
\hline 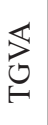 & $\frac{n}{\stackrel{2}{\infty}}$ & $\begin{array}{l}0 \\
\infty \\
\infty \\
0 \\
0\end{array}$ & $\begin{array}{l}\stackrel{0}{8} \\
\stackrel{+}{+}\end{array}$ & $\begin{array}{l}\text { ते } \\
\text { à }\end{array}$ & $\begin{array}{l}\stackrel{0}{\mathfrak{1}} \\
\stackrel{n}{\approx}\end{array}$ & $\begin{array}{l}0 \\
\tilde{n} \\
\tilde{n} \\
\approx\end{array}$ & 을 & $\frac{n}{8}$ & $\frac{\hat{\infty}}{\stackrel{0}{\hat{~}}}$ & $\frac{n}{\vec{J}}$ & 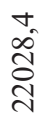 & $\begin{array}{l}n \\
\stackrel{n}{\sim} \\
\tilde{n}\end{array}$ & $\begin{array}{l}0 \\
0 \\
0 \\
0 \\
\infty \\
0\end{array}$ & 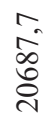 & $\begin{array}{l}\stackrel{0}{1} \\
\hat{\delta} \\
\hat{0} \\
\text { }\end{array}$ & 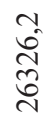 \\
\hline $\begin{array}{l}\tilde{0} \\
0 \\
0\end{array}$ & $\hat{\vec{\lambda}}$ & $\overrightarrow{\hat{a}}$ & $\begin{array}{l}\infty \\
\stackrel{\infty}{m}\end{array}$ & $\stackrel{0}{8}$ & $\begin{array}{l}\stackrel{a}{)} \\
\text { in }\end{array}$ & $\frac{\hat{0}}{n}$ & $\stackrel{n}{\exists}$ & $\begin{array}{l}0 \\
\infty \\
\infty \\
\infty\end{array}$ & $\stackrel{\circ}{\underset{f}{f}}$ & $\begin{array}{l}0 \\
\sim \\
\sim \\
\sim\end{array}$ & $\frac{m}{n}$ & $\begin{array}{l}\nabla_{n} \\
\infty \\
i n \\
i n\end{array}$ & $\stackrel{0}{\vec{i}}$ & $\begin{array}{l}n \\
\tilde{n} \\
n\end{array}$ & $\frac{N}{6}$ & సิ \\
\hline 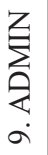 & 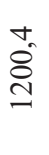 & $\begin{array}{l}n \\
\text { J্t } \\
\stackrel{+}{ \pm}\end{array}$ & שี & $\begin{array}{l}\nabla^{\prime} \\
\infty \\
\infty\end{array}$ & $\begin{array}{l}\hat{\infty} \\
\infty \\
\tilde{n}\end{array}$ & $\begin{array}{l}0 \\
\infty \\
\infty \\
\infty\end{array}$ & 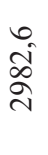 & $\begin{array}{l}\hat{\theta} \\
\stackrel{0}{0}\end{array}$ & $\begin{array}{l}n \\
\text { â } \\
\text { ลे }\end{array}$ & 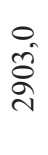 & $\begin{array}{l}\hat{n} \\
\hat{n}\end{array}$ & $\begin{array}{l}0 \\
0 \\
n \\
\tilde{n} \\
m\end{array}$ & $\stackrel{\infty}{\equiv}$ & ลे & $\begin{array}{l}0 \\
0 \\
0 \\
0 \\
0\end{array}$ & $\frac{\hat{\partial}}{\hat{y}}$ \\
\hline 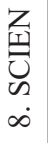 & $\underset{i n}{\stackrel{\infty}{\circ}}$ & ๗ેे & $\begin{array}{l}n \\
\tilde{n} \\
n\end{array}$ & $\stackrel{\sigma_{0}}{\Xi}$ & $\begin{array}{l}\stackrel{m}{n} \\
\stackrel{0}{n}\end{array}$ & $\begin{array}{l}\stackrel{0}{8} \\
\stackrel{\infty}{\infty}\end{array}$ & $\begin{array}{l}n \\
\tilde{n} \\
n\end{array}$ & $\begin{array}{l}\text { ते } \\
\text { n̂. }\end{array}$ & $\frac{n}{a}$ & $\begin{array}{l}m \\
\tilde{\delta} \\
\infty\end{array}$ & $\begin{array}{l}m \\
\infty \\
\infty\end{array}$ & 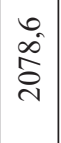 & $\overrightarrow{\tilde{\delta}}$ & 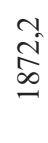 & $\begin{array}{l}\infty \\
\infty \\
\infty \\
\infty\end{array}$ & $\begin{array}{l}+ \\
\stackrel{\Delta}{2} \\
i \\
i\end{array}$ \\
\hline$\frac{\sqrt[I]{2}}{r}$ & $\stackrel{0}{\stackrel{0}{\infty}}$ & $\overrightarrow{\hat{\sigma}}$ & $\begin{array}{l}\stackrel{0}{\Xi} \\
\equiv\end{array}$ & $\begin{array}{l}0 \\
\stackrel{g}{ \pm}\end{array}$ & 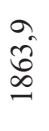 & \begin{tabular}{l}
$n$ \\
\multirow{\infty}{*}{} \\
$\stackrel{2}{N}$
\end{tabular} & $\begin{array}{l}\stackrel{0}{ } \\
\infty \\
\infty \\
\infty\end{array}$ & $\hat{i}$ & $\begin{array}{l}0 \\
\infty \\
\infty \\
0\end{array}$ & 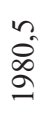 & $\begin{array}{l}\text { ֶू } \\
\stackrel{2}{2}\end{array}$ & 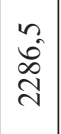 & $\overrightarrow{\hat{\sigma}^{0}}$ & $\begin{array}{l}n \\
\infty \\
\infty \\
\infty\end{array}$ & $\begin{array}{l}\dot{\sigma}_{n} \\
\stackrel{n}{n}\end{array}$ & $\frac{n}{\sqrt[n]{n}}$ \\
\hline $\begin{array}{l}Z \\
\qquad \\
0 \\
0\end{array}$ & 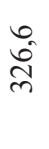 & $\begin{array}{l}\infty \\
i \\
q\end{array}$ & 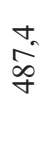 & ते & 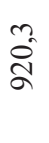 & $\begin{array}{l}\stackrel{0}{\infty} \\
\dot{0} \\
ٍ\end{array}$ & $\begin{array}{l}\infty \\
\stackrel{\infty}{n} \\
\stackrel{n}{n}\end{array}$ & 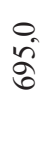 & $\begin{array}{l}0 \\
\dot{\infty} \\
\stackrel{0}{r}\end{array}$ & $\underset{\infty}{\infty}$ & ڤે & $\begin{array}{c}0 \\
\vdots \\
\vdots \\
\infty\end{array}$ & $\stackrel{0}{\stackrel{0}{ }}$ & 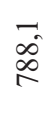 & $\underset{\infty}{\stackrel{0}{\infty}}$ & $\begin{array}{l}n \\
\tilde{0} \\
\tilde{0}\end{array}$ \\
\hline $\begin{array}{l}\text { o } \\
\text { Z } \\
\text { 少 } \\
\text { in }\end{array}$ & $\begin{array}{l}0 \\
\dot{\delta} \\
\stackrel{丶}{f}\end{array}$ & $\overrightarrow{\mathbb{N}}$ & $\frac{N}{\infty}$ & $\sqrt{6}$ & $\begin{array}{l}0 \\
\stackrel{2}{\infty} \\
\infty\end{array}$ & గ్ & $\stackrel{n}{\vec{J}}$ & ลิ & $\begin{array}{l}\infty \\
\stackrel{ \pm}{\Delta} \\
\stackrel{0}{0}\end{array}$ & $\begin{array}{l}\infty \\
\text { กิ } \\
\text { ல̂ }\end{array}$ & 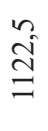 & $\begin{array}{l}n \\
2 \\
=\end{array}$ & $\begin{array}{l}0 \\
\infty \\
\infty \\
0 \\
0\end{array}$ & 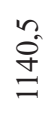 & $\begin{array}{l}0 \\
\stackrel{1}{n} \\
\cong\end{array}$ & $\stackrel{\hat{\circ}}{\stackrel{2}{2}}$ \\
\hline 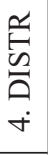 & $\begin{array}{l}0 \\
\stackrel{\text { ปे }}{\text { ते }}\end{array}$ & 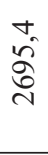 & \begin{tabular}{l}
0 \\
$\stackrel{n}{n}$ \\
\multirow{n}{n}{}
\end{tabular} & 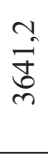 & $\begin{array}{l}n \\
\stackrel{\tilde{\sigma}}{\sigma}\end{array}$ & 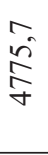 & $\begin{array}{l}\hat{n} \\
\text { in } \\
0 \\
n\end{array}$ & $\begin{array}{l}n \\
\hat{n} \\
\hat{n}\end{array}$ & $\begin{array}{l}m \\
2 \\
\stackrel{2}{\sigma} \\
\dot{\gamma}\end{array}$ & \begin{tabular}{l}
$\overrightarrow{6}$ \\
\multirow{6}{0}{} \\
+
\end{tabular} & $\vec{~}$ & $\frac{n}{f}$ & $\begin{array}{l}0 \\
i \\
i \\
\text { o } \\
\text { f }\end{array}$ & 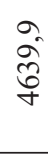 & $\overrightarrow{0}$ & $\frac{n}{n}$ \\
\hline 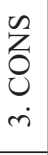 & $\stackrel{n}{n}$ & $\stackrel{\infty}{\stackrel{+}{\sim}}$ & $\stackrel{n}{\circ}$ & $\begin{array}{l}0 \\
\text { J } \\
\text { I }\end{array}$ & $\frac{\sim}{\text { กิ }}$ & $\begin{array}{l}\text { ñ } \\
\text { है } \\
\text { हे }\end{array}$ & 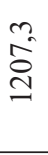 & $\begin{array}{l}\hat{0} \\
0 \\
0\end{array}$ & 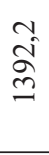 & $\begin{array}{l}0 \\
\stackrel{\nabla}{J} \\
\text { 年 }\end{array}$ & $\begin{array}{l}+ \\
\stackrel{n}{n} \\
\stackrel{n}{n}\end{array}$ & 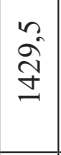 & $\begin{array}{l}\circ \\
\stackrel{\text { Oे }}{\text { In }}\end{array}$ & $\begin{array}{l}m \\
\tilde{n} \\
\tilde{m}\end{array}$ & $\begin{array}{l}n \\
\tilde{n} \\
\hat{\sigma}\end{array}$ & ñ \\
\hline 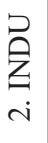 & $\vec{\Omega}$ & 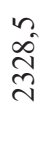 & 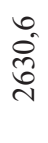 & $\frac{\vec{g}}{m}$ & $\begin{array}{l}0 \\
\text { I } \\
\text { ले }\end{array}$ & $\frac{n}{\stackrel{n}{\sim}}$ & $\begin{array}{l}0 \\
\stackrel{\Omega}{\circ} \\
\text { ले }\end{array}$ & $\underset{0}{\frac{0}{6}}$ & $\stackrel{\sim}{\hat{m}}$ & $\begin{array}{l}\stackrel{0}{\Xi} \\
\stackrel{F}{F}\end{array}$ & \begin{tabular}{l}
$n$ \\
2 \\
\multirow{\gamma}{*}{}
\end{tabular} & $\begin{array}{l}a \\
\dot{m} \\
\dot{n}\end{array}$ & 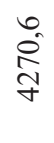 & $\stackrel{n}{\stackrel{n}{F}}$ & $\overrightarrow{0}$ & $\underset{\mathfrak{f}}{\stackrel{5}{n}}$ \\
\hline 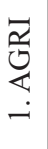 & $\begin{array}{l}+ \\
\stackrel{\sim}{n} \\
m\end{array}$ & $\hat{\sigma}$ & 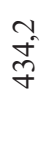 & $\frac{n}{f}$ & $\underset{⿱}{\mathbb{f}}$ & $\hat{\circ}$ & $\frac{N}{7}$ & 咅 & $\begin{array}{l}0 \\
\infty \\
\infty \\
\infty\end{array}$ & ले & $\frac{n}{n}$ & $\begin{array}{l}\infty \\
\tilde{\delta} \\
\delta\end{array}$ & $\frac{m}{m}$ & $\begin{array}{l}\dot{\theta}_{0} \\
\stackrel{\circ}{\circ}\end{array}$ & $\begin{array}{l}0 \\
\infty \\
\infty \\
0\end{array}$ & $\stackrel{+}{i}$ \\
\hline$\stackrel{\bar{\Xi}}{\check{D}}$ & હ্ণ & ষ্ণ & ஜ̊̊ి & ஜ̊ & 홍 & $\begin{array}{l}\infty \\
\stackrel{8}{8}\end{array}$ & ஓे & $\stackrel{\circ}{\stackrel{ }{\circ}}$ & ت্ & $\frac{N}{\stackrel{N}{*}}$ & $\frac{m}{\stackrel{n}{\sigma}}$ & $\underset{\sim}{\stackrel{\nabla}{\sigma}}$ & $\frac{n}{\stackrel{n}{d}}$ & $\frac{0}{8}$ & $\frac{\bar{c}}{\mathrm{i}}$ & $\frac{\infty}{\stackrel{d}{~}}$ \\
\hline
\end{tabular}




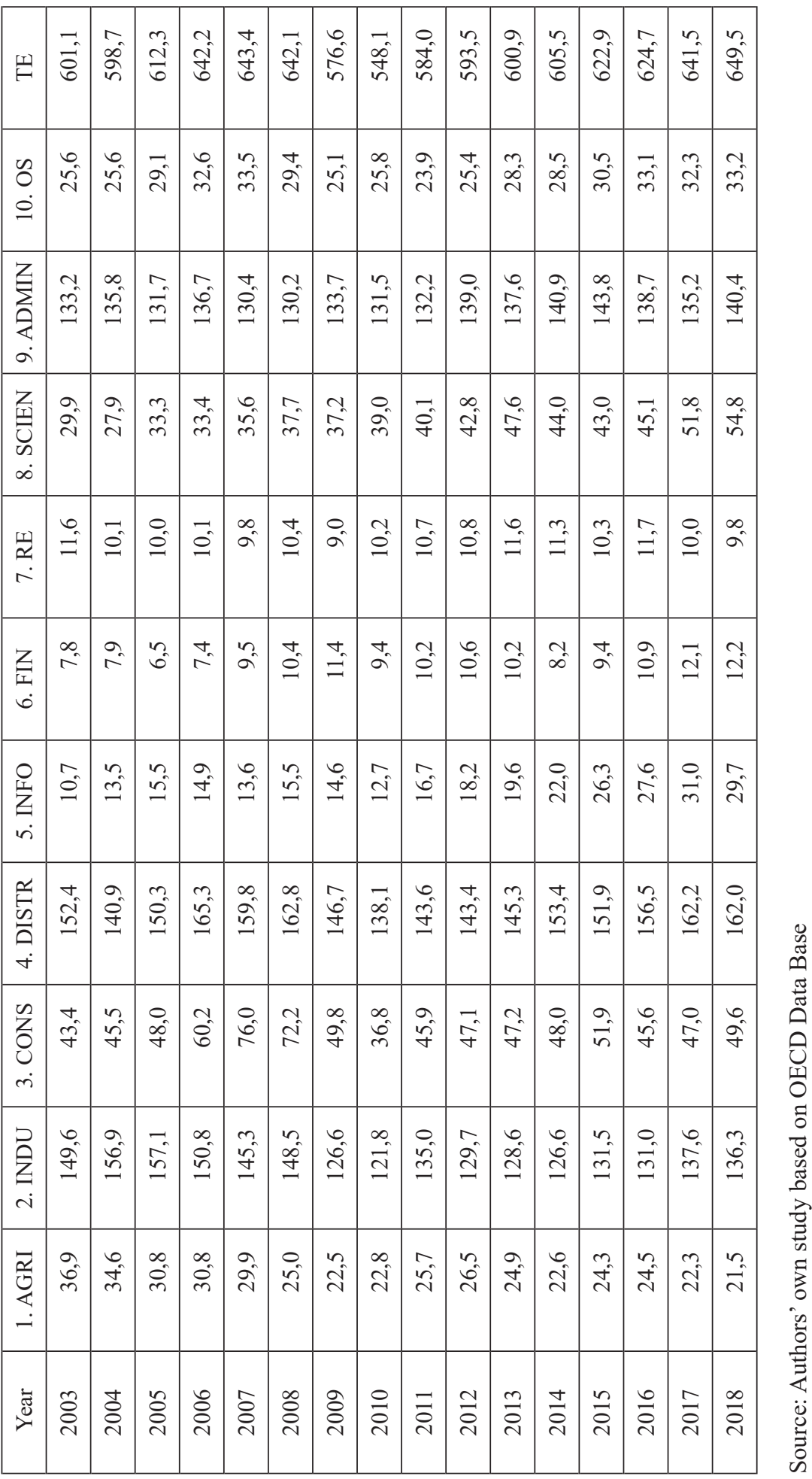




\begin{tabular}{|c|c|c|c|c|c|c|c|c|c|c|c|c|c|c|c|c|}
\hline 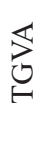 & $\begin{array}{l}n \\
\hat{n} \\
\frac{0}{\alpha}\end{array}$ & 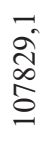 & $\frac{O}{N}$ & 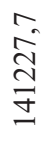 & 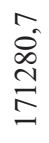 & $\begin{array}{l}\hat{\infty} \\
\stackrel{n}{n} \\
\stackrel{n}{N}\end{array}$ & \begin{tabular}{l} 
N \\
\multirow{J}{Z}{} \\
$\infty$ \\
$\infty$
\end{tabular} & $\frac{N}{\frac{n}{6}}$ & 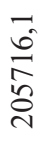 & $\begin{array}{l}n \\
\text { గ̂ } \\
\text { గె } \\
\infty \\
\infty\end{array}$ & 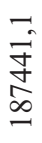 & $\begin{array}{l}\nabla_{0} \\
\sigma^{\infty} \\
\infty \\
\infty\end{array}$ & $\begin{array}{l}n \\
\stackrel{n}{0} \\
\infty \\
0\end{array}$ & $\begin{array}{l}\vec{n} \\
\text { ñ } \\
\text { ñ } \\
=\end{array}$ & 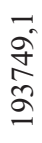 & $\begin{array}{l}m \\
\infty \\
\stackrel{+}{\sigma} \\
\stackrel{2}{v}\end{array}$ \\
\hline $\begin{array}{l}\tilde{0} \\
0 \\
0\end{array}$ & $\overrightarrow{\stackrel{f}{\sim}}$ & $\begin{array}{l}\overrightarrow{\hat{\sigma}} \\
\hat{v}\end{array}$ & $\begin{array}{l}\infty \\
\infty \\
\infty \\
0\end{array}$ & $\begin{array}{l}\tilde{n} \\
\tilde{n} \\
n\end{array}$ & $\begin{array}{l}\hat{\sigma} \\
\hat{\sigma} \\
\vec{y}\end{array}$ & $\begin{array}{r}\hat{\curvearrowright} \\
\stackrel{\gamma}{\gamma}\end{array}$ & \begin{tabular}{l}
$\infty$ \\
$i$ \\
$\infty$ \\
\multirow{f}{*}{}
\end{tabular} & $\frac{n}{\stackrel{f}{f}}$ & $\hat{\frac{\hat{\sigma}}{\gamma}}$ & 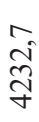 & $\begin{array}{l}\infty \\
\sigma^{\circ} \\
\frac{\sigma}{\gamma}\end{array}$ & $\begin{array}{l}\vec{\Xi} \\
\vec{\exists}\end{array}$ & $\frac{\vec{n}}{\stackrel{n}{n}}$ & $\begin{array}{l}\stackrel{n}{\mathbb{T}} \\
\text { aे }\end{array}$ & \begin{tabular}{l}
$J_{n}$ \\
$\hat{n}$ \\
\multirow{\gamma}{*}{}
\end{tabular} & \begin{tabular}{l}
$n$ \\
$\stackrel{2}{\gamma}$ \\
\multirow{\gamma}{*}{}
\end{tabular} \\
\hline 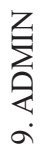 & 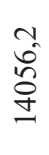 & $\begin{array}{l}\vec{n} \\
\infty \\
\triangleq\end{array}$ & $\begin{array}{l}n \\
0 \\
n \\
\infty \\
\infty\end{array}$ & 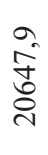 & 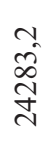 & $\begin{array}{l}\text { ते } \\
\text { के } \\
D^{0}\end{array}$ & 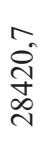 & 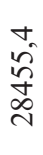 & 苍 & 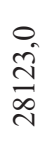 & \begin{tabular}{l}
$a$ \\
\multirow{N}{*}{} \\
in \\
$\infty$
\end{tabular} & 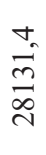 & 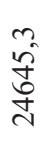 & 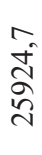 & 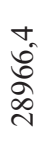 & $\frac{\sqrt{6}}{\frac{\pi}{m}}$ \\
\hline $\begin{array}{l}Z \\
\text { Z्工 } \\
\text { U } \\
\infty \\
\infty\end{array}$ & $\begin{array}{l}0 \\
0 \\
\text { +⿱ } \\
\infty \\
n\end{array}$ & $\begin{array}{l}\text { on } \\
\frac{\infty}{6}\end{array}$ & $\begin{array}{l}N \\
\infty \\
2 \\
\curvearrowright\end{array}$ & $\frac{\infty}{\hat{\infty}}$ & $\begin{array}{l}0 \\
\stackrel{5}{ } \\
\stackrel{\Xi}{=}\end{array}$ & $\begin{array}{l}\infty \\
0 \\
0 \\
\infty \\
\text { D }\end{array}$ & $\begin{array}{l}n \\
\infty \\
\infty \\
\end{array}$ & $\begin{array}{l}\stackrel{g}{ \pm} \\
\underset{J}{ \pm}\end{array}$ & 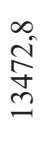 & 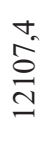 & $\begin{array}{l}\hat{\sigma} \\
ٌ \\
\triangleq\end{array}$ & $\begin{array}{l}\hat{\sigma} \\
\hat{\Xi} \\
\text { }\end{array}$ & \begin{tabular}{l} 
? \\
\multirow{J}{0}{}
\end{tabular} & 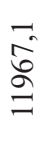 & $\frac{\vec{J}}{\stackrel{J}{J}}$ & 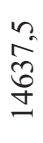 \\
\hline$\frac{\sqrt{2}}{r}$ & $\underset{\sim}{\stackrel{\infty}{a}}$ & $\begin{array}{l}0 \\
\stackrel{f}{+} \\
m\end{array}$ & $\begin{array}{l}0 \\
8 \\
0 \\
\infty\end{array}$ & 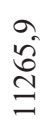 & $\begin{array}{l}\text { r } \\
\text { nn } \\
\tilde{n} \\
\tilde{n}\end{array}$ & $\begin{array}{l}\infty \\
0 \\
\infty \\
\infty \\
=\end{array}$ & $\begin{array}{l}\nabla_{0} \\
J_{0} \\
0 \\
0\end{array}$ & $\begin{array}{l}\nabla_{0} \\
\infty \\
\infty \\
0\end{array}$ & $\begin{array}{l}0 \\
\stackrel{0}{0} \\
\stackrel{0}{\infty} \\
\stackrel{0}{0}\end{array}$ & $\frac{n}{n}$ & \begin{tabular}{l}
0 \\
\multirow{2}{*}{} \\
0
\end{tabular} & $\begin{array}{l}\vec{\infty} \\
\stackrel{0}{0}\end{array}$ & $\begin{array}{l}n \\
\infty \\
n \\
\exists\end{array}$ & $\begin{array}{l}\infty \\
\hat{\sigma} \\
\stackrel{\infty}{ \pm}\end{array}$ & $\begin{array}{l}0 \\
\infty \\
10 \\
0\end{array}$ & $\begin{array}{l}n \\
2 \\
2 \\
2\end{array}$ \\
\hline $\begin{array}{l}Z \\
\text { Z } \\
\dot{0}\end{array}$ & $\frac{0}{0}$ & $\begin{array}{l}n \\
\hat{n} \\
n \\
n\end{array}$ & $\hat{\stackrel{2}{2}}$ & 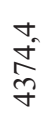 & 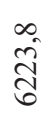 & $\begin{array}{l}0 \\
\stackrel{0}{n} \\
\infty \\
\infty\end{array}$ & $\begin{array}{l}n \\
n \\
n \\
\infty \\
\infty\end{array}$ & $\begin{array}{l}\hat{n} \\
\tilde{\infty} \\
\infty\end{array}$ & $\begin{array}{l}\infty \\
\stackrel{\infty}{2} \\
\hat{n}\end{array}$ & $\begin{array}{l}0 \\
\infty \\
\infty \\
\infty \\
\infty\end{array}$ & $\underset{\infty}{\stackrel{0}{N}}$ & مे & $\stackrel{\circ}{\stackrel{\circ}{2}}$ & $\frac{N}{N}$ & 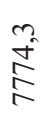 & $\frac{n}{\hat{a}}$ \\
\hline $\begin{array}{l}\text { O } \\
\text { Z } \\
\text { in }\end{array}$ & $\begin{array}{r}\underset{\sim}{\mathbb{f}} \\
\underset{f}{2}\end{array}$ & $\begin{array}{l}\infty \\
\infty \\
\infty \\
+\infty\end{array}$ & 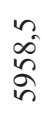 & 衣 & $\begin{array}{l}\dot{n}^{2} \\
\hat{\alpha}\end{array}$ & $\begin{array}{l}0 \\
\stackrel{0}{0} \\
\stackrel{=}{0}\end{array}$ & $\begin{array}{l}\dot{\sigma}_{0} \\
\text { } \\
\text { }\end{array}$ & 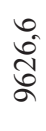 & $\begin{array}{l}n \\
n \\
8\end{array}$ & $\frac{0}{n} \frac{0}{n}$ & $\overrightarrow{\widetilde{I}}$ & $\begin{array}{l}\text { ñ } \\
\stackrel{N}{ } \\
\text { Jू }\end{array}$ & సิ & 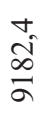 & $\begin{array}{l}0 \\
\text { ô } \\
0\end{array}$ & $\begin{array}{l}n \\
\text { ñ } \\
=\end{array}$ \\
\hline 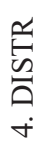 & 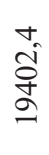 & $\begin{array}{l}\vec{n} \\
\tilde{\sigma} \\
\text { ते }\end{array}$ & 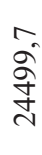 & $\begin{array}{l}\nabla_{0} \\
\underset{\sim}{\infty} \\
\stackrel{\infty}{N}\end{array}$ & $\begin{array}{l}0 \\
\hat{\infty} \\
\infty \\
\tilde{m}\end{array}$ & $\begin{array}{l}n \\
\text { in } \\
\infty \\
o \\
o\end{array}$ & $\begin{array}{l}\text { ñ } \\
\text { ळे } \\
\text { ले }\end{array}$ & \begin{tabular}{l}
0 \\
$i$ \\
$\infty$ \\
\multirow{2}{\infty}{} \\
$m$
\end{tabular} & $\begin{array}{c}\vec{n} \\
\stackrel{n}{n}\end{array}$ & 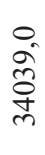 & $\begin{array}{l}\hat{\sigma} \\
\hat{b} \\
\text { లె }\end{array}$ & $\begin{array}{c}n \\
\tilde{n} \\
\tilde{n} \\
m\end{array}$ & 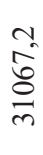 & $\begin{array}{l}{ }_{n} \\
\text { N } \\
\text { ñ } \\
\text { no }\end{array}$ & 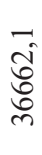 & $\begin{array}{l}\infty \\
\underset{+}{ \pm} \\
\frac{J}{\forall}\end{array}$ \\
\hline 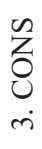 & $\begin{array}{l}2 \\
\hat{D} \\
\infty \\
\text { in }\end{array}$ & $\overrightarrow{\frac{n}{+}}$ & 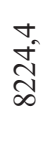 & $\begin{array}{l}n \\
\text { ڤे } \\
\text { }\end{array}$ & $\begin{array}{l}\infty \\
\stackrel{0}{\Xi} \\
\Xi\end{array}$ & $\begin{array}{l}\overrightarrow{0} \\
\dot{0} \\
\dot{O}\end{array}$ & 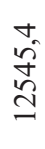 & $\begin{array}{l}N \\
n \\
\infty \\
\infty \\
\end{array}$ & 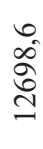 & $\begin{array}{l}\vec{\Xi} \\
\bar{a}\end{array}$ & $\frac{n}{2}$ & $\begin{array}{l}\infty \\
\text { లి } \\
\text { రి }\end{array}$ & $\stackrel{g}{\stackrel{g}{J}}$ & $\frac{0}{\stackrel{0}{\circ}}$ & $\begin{array}{l}\text { กิ } \\
\text { กิ } \\
\text { ชิ }\end{array}$ & 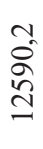 \\
\hline 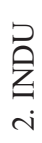 & 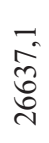 & $\begin{array}{l}\hat{n} \\
\hat{0} \\
\text { के }\end{array}$ & 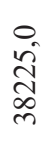 & $\begin{array}{l}\hat{n} \\
\tilde{N} \\
\text { ja }\end{array}$ & $\begin{array}{l}\infty \\
\text { f } \\
\text { f } \\
\stackrel{+}{n}\end{array}$ & $\begin{array}{l}\nabla_{0} \\
6 \\
0 \\
\delta\end{array}$ & 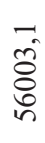 & $\stackrel{\vec{\partial}}{\overrightarrow{0}}$ & \begin{tabular}{l}
$a$ \\
\multirow{2}{*}{} \\
\multirow{3}{*}{}
\end{tabular} & $\begin{array}{l}- \\
\text { లె } \\
\infty \\
\text { in }\end{array}$ & \begin{tabular}{l}
$m$ \\
\multirow{D}{*}{} \\
0 \\
$\infty$ \\
$n$
\end{tabular} & 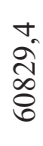 & $\begin{array}{l}-2 \\
6 \\
0 \\
\dot{1} \\
n\end{array}$ & $\begin{array}{l}\infty \\
i \\
\infty \\
\infty \\
n\end{array}$ & $\stackrel{\vec{a}}{\hat{\sigma}}$ & $\frac{\infty}{\infty}$ \\
\hline$\underset{\sim}{\overrightarrow{0}}$ & $\begin{array}{l}\hat{n} \\
\hat{n} \\
\hat{n}\end{array}$ & 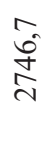 & $\begin{array}{l}0 \\
\stackrel{+}{\sigma} \\
\end{array}$ & 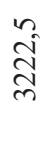 & $\begin{array}{l}0 \\
\underset{0}{0} \\
\frac{1}{n}\end{array}$ & $\begin{array}{l}\stackrel{N}{\sigma} \\
\stackrel{0}{\sigma}\end{array}$ & $\begin{array}{l}\vec{b} \\
\infty \\
m\end{array}$ & $\begin{array}{l}0 \\
i \\
n \\
n\end{array}$ & $\begin{array}{l}0 \\
\stackrel{2}{2} \\
\infty\end{array}$ & 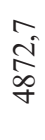 & $\stackrel{m}{\tilde{n}}$ & $\frac{n}{\dot{f}}$ & \begin{tabular}{l}
+ \\
$\underset{\sigma}{\sigma}$ \\
\multirow{\sigma}{*}{}
\end{tabular} & 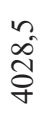 & 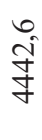 & 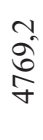 \\
\hline 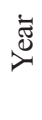 & §ీ̊ & ঠి & ஜ̊ & \&̊․ㅇ & 홍 & $\stackrel{\infty}{\stackrel{8}{\circ}}$ & ஓे & $\stackrel{\circ}{\stackrel{0}{0}}$ & $\bar{\Xi}$ & $\stackrel{\sim}{\stackrel{2}{2}}$ & $\frac{m}{\tilde{\gamma}}$ & 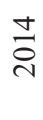 & $\frac{n}{2}$ & $\frac{0}{0}$ & $\frac{\overline{0}}{\bar{\gamma}}$ & $\stackrel{\infty}{\stackrel{\infty}{)}}$ \\
\hline
\end{tabular}




\begin{tabular}{|c|c|c|c|c|c|c|c|c|c|c|c|c|c|c|c|c|}
\hline 岂 & $\begin{array}{l}\vec{\infty} \\
\infty \\
\infty \\
\infty\end{array}$ & 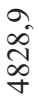 & 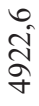 & $\begin{array}{l}0 \\
\text { ळ. } \\
\text { ஓे }\end{array}$ & ळे & $\begin{array}{l}\text { च } \\
\text { ঠे } \\
\text { N }\end{array}$ & $\stackrel{\overrightarrow{0}}{\stackrel{\vec{n}}{n}}$ & Ň & $\begin{array}{c}\dot{J} \\
\stackrel{0}{0}\end{array}$ & 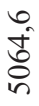 & $\begin{array}{l}\hat{\sigma} \\
\stackrel{\infty}{\infty} \\
0 \\
0\end{array}$ & 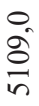 & $\frac{a}{n}$ & $\begin{array}{l}\text { n } \\
\text { to } \\
\text { N }\end{array}$ & $\begin{array}{l}\vec{\sigma} \\
\dot{0} \\
\text { in }\end{array}$ & 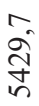 \\
\hline $\begin{array}{l}\tilde{O} \\
\dot{0} \\
0\end{array}$ & 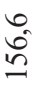 & $\begin{array}{c}\dot{n}^{2} \\
\stackrel{n}{n}\end{array}$ & $\stackrel{?}{\stackrel{\infty}{ \pm}}$ & $\begin{array}{l}\sigma_{0} \\
\stackrel{n}{n}\end{array}$ & $\begin{array}{l}0 \\
0 \\
0\end{array}$ & ڤె & గ్రి & $\overrightarrow{6}$ & $\stackrel{N}{I}$ & $\stackrel{\circ}{\circ}$ & $\begin{array}{l}0 \\
\infty \\
\infty\end{array}$ & ๙ิ & $\stackrel{\nabla}{\stackrel{+}{\infty}}$ & $\begin{array}{l}\hat{a} \\
\infty \\
\infty\end{array}$ & $\hat{\sigma}$ & $\begin{array}{l}\infty \\
\stackrel{0}{0}\end{array}$ \\
\hline 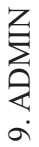 & 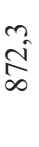 & 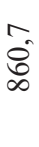 & $\begin{array}{l}0 \\
\frac{0}{\infty}\end{array}$ & हे & $\hat{\partial}$ & $\begin{array}{l}\dot{\sigma}^{2} \\
\text { }\end{array}$ & $\stackrel{\infty}{\infty}$ & Бூ & $\stackrel{m}{\infty}$ & $\frac{n}{\infty}$ & $\stackrel{+}{\nabla_{0}}$ & 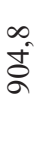 & $\frac{\bar{m}}{\sigma}$ & 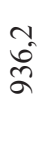 & $\begin{array}{l}\sigma_{0} \\
\sigma\end{array}$ & $\begin{array}{l}0 \\
\stackrel{\circ}{\circ} \\
\text { হ̆ }\end{array}$ \\
\hline $\begin{array}{l}\underset{1}{Z} \\
\underset{\sim}{\operatorname{m}} \\
\infty \\
\infty\end{array}$ & $\begin{array}{l}0 \\
\hat{\sigma} \\
n\end{array}$ & $\hat{\sigma}^{2}$ & 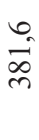 & $\begin{array}{l}\infty \\
\stackrel{\infty}{\circ} \\
\text { in }\end{array}$ & $\frac{n}{\nabla}$ & $\stackrel{\sim}{\sim}$ & $\stackrel{\infty}{\stackrel{\infty}{\sim}}$ & $\frac{n}{\partial}$ & ஸ̂ & $\frac{N}{\nabla}$ & $\stackrel{\circ}{\stackrel{\circ}{\sim}}$ & $\stackrel{\vec{\sigma}}{\vec{\sigma}}$ & 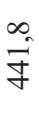 & $\begin{array}{l}\dot{\sigma} \\
i n \\
\dot{\sigma}\end{array}$ & $\vec{\sigma}$ & $\begin{array}{l}0 \\
6 \\
\delta \\
\sigma\end{array}$ \\
\hline$\frac{\sqrt{2}}{\sim}$ & N & $\stackrel{\circ}{N}$ & $\stackrel{m}{\infty}$ & న & ๙ู & 조 & $\stackrel{\infty}{i}$ & ๙ָ & $\stackrel{\infty}{\infty}$ & $\vec{n}$ & ڤ̊ & ñ & ñ & $\begin{array}{l}0 \\
0 \\
2\end{array}$ & $\underset{\infty}{+}$ & $\begin{array}{l}0 \\
2\end{array}$ \\
\hline$\frac{Z}{\dot{Z}}$ & 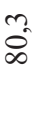 & $\stackrel{\nabla_{\infty}}{\nabla^{\prime}}$ & $\underset{\infty}{\nabla_{n}}$ & $\stackrel{m}{\infty}$ & $\hat{N}^{\infty}$ & $\stackrel{\circ}{\circ}$ & $\stackrel{+}{\circ}$ & $\stackrel{\infty}{\infty}$ & $\stackrel{0}{\infty}$ & $\begin{array}{l}0 \\
\text { बं }\end{array}$ & $\begin{array}{l}0 \\
\stackrel{n}{2}\end{array}$ & $\frac{\sigma_{n}}{\hat{a}}$ & $\stackrel{\circ}{2}$ & $\stackrel{\infty}{\curvearrowleft}$ & $\stackrel{+}{a}$ & $\stackrel{+}{d}$ \\
\hline $\begin{array}{l}0 \\
\text { 岌 } \\
\text { 它 }\end{array}$ & $\frac{n}{d}$ & గูర & ๙ิ & $\stackrel{n}{0}$ & 二 & ָ̊ & $\begin{array}{l}0 \\
\stackrel{m}{n}\end{array}$ & $\stackrel{\Omega}{\Omega}$ & $\stackrel{n}{\stackrel{n}{\sim}}$ & $\begin{array}{l}\infty \\
\text { ల్ } \\
\text { తn }\end{array}$ & స్ & $\stackrel{m}{m}$ & 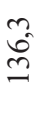 & $\stackrel{\Xi}{\Xi}$ & $\begin{array}{l}a \\
\tilde{y}\end{array}$ & $\begin{array}{l}\infty \\
\stackrel{+}{n}\end{array}$ \\
\hline$\frac{\widetilde{\sigma}}{\stackrel{\sim}{\sigma}}$ & $\begin{array}{l}0 \\
0 \\
0 \\
0\end{array}$ & $\begin{array}{l}\hat{n} \\
\text { n }\end{array}$ & $\begin{array}{l}n \\
\stackrel{n}{n} \\
=\end{array}$ & $\begin{array}{l}\infty \\
\stackrel{\infty}{=}\end{array}$ & \begin{tabular}{l}
0 \\
\multirow{2}{0}{} \\
$=$
\end{tabular} & $\begin{array}{l}\infty \\
\stackrel{\infty}{ \pm} \\
\stackrel{\sim}{ \pm}\end{array}$ & $\stackrel{\vec{\sim}}{\stackrel{\sim}{J}}$ & 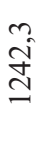 & $\stackrel{\sigma_{n}}{\stackrel{N}{N}}$ & 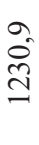 & $\begin{array}{l}\hat{\sigma} \\
\stackrel{n}{\sim}\end{array}$ & $\begin{array}{l}\text { مे } \\
\text { กี }\end{array}$ & 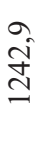 & $\begin{array}{l}n \\
\stackrel{\infty}{+}\end{array}$ & $\begin{array}{l}\text { ㅇ } \\
\text { ปூ } \\
\text { ป̂ }\end{array}$ & 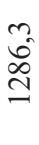 \\
\hline 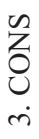 & 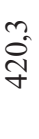 & $\stackrel{\stackrel{\sim}{\sim}}{\stackrel{\sim}{\sigma}}$ & $\begin{array}{l}\infty \\
\stackrel{n}{\sim}\end{array}$ & 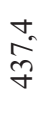 & $\begin{array}{l}\stackrel{\sim}{+} \\
\stackrel{\sim}{+}\end{array}$ & $\begin{array}{l}\text { f } \\
\text { f }\end{array}$ & ๙ิ & $\stackrel{n}{\approx}$ & $\frac{n}{8}$ & $\stackrel{n}{\nexists}$ & $\stackrel{\vec{g}}{\vec{\sigma}}$ & $\stackrel{n}{\exists}$ & $\begin{array}{l}0 \\
\stackrel{0}{\circ}\end{array}$ & ָ̊ & ֶ̊ & ঠ̊ \\
\hline 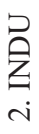 & $\begin{array}{l}\stackrel{\sim}{\infty} \\
\stackrel{\sim}{J}\end{array}$ & $\stackrel{\vec{f}}{\stackrel{f}{Z}}$ & \begin{tabular}{l}
$n$ \\
2 \\
\multirow{2}{*}{}
\end{tabular} & $\begin{array}{l}0 \\
\dot{+} \\
\pm \\
\pm\end{array}$ & $\begin{array}{l}\nabla^{2} \\
\stackrel{\text { N }}{=}\end{array}$ & $\hat{n}$ & $\begin{array}{l}\text { o } \\
\text { ป } \\
\text { I }\end{array}$ & $\begin{array}{l}\infty \\
\infty \\
\stackrel{\infty}{n}\end{array}$ & 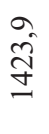 & $\begin{array}{l}0 \\
0 \\
\text { } \\
\Xi\end{array}$ & $\begin{array}{l}0 \\
\stackrel{0}{ \pm} \\
\stackrel{1}{ \pm}\end{array}$ & \begin{tabular}{l}
$a$ \\
$\tilde{n}$ \\
\multirow{2}{*}{}
\end{tabular} & $\begin{array}{l}\hat{8} \\
\stackrel{n}{2}\end{array}$ & 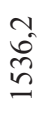 & $\begin{array}{l}n \\
\stackrel{n}{n} \\
n\end{array}$ & $\begin{array}{l}\text { n } \\
\text { o } \\
n\end{array}$ \\
\hline$\underset{\sim}{\stackrel{\nabla}{\sim}}$ & $\begin{array}{l}\nabla^{\prime} \\
\stackrel{\infty}{\infty}\end{array}$ & న్ & $\stackrel{\nabla_{0}}{\infty_{0}}$ & $\begin{array}{l}0 \\
\pm \\
\pm\end{array}$ & $\stackrel{\overrightarrow{0}}{2}$ & $\begin{array}{l}\nabla_{0} \\
\infty \\
0 \\
0\end{array}$ & $\underline{\sigma}$ & $\vec{a}$ & ชิ & $\begin{array}{l}\sigma_{0} \\
\qquad 0\end{array}$ & $\sqrt{6}$ & 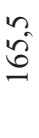 & $\stackrel{n}{\tilde{\sigma}}$ & $\begin{array}{l}\hat{0} \\
0\end{array}$ & $\begin{array}{l}+ \\
\text { ชู }\end{array}$ & $\hat{n}$ \\
\hline$\stackrel{\Xi}{\bar{Z}}$ & ֻ̊ণ & ঠ্ণ & $\stackrel{\overbrace{}}{\bigodot}$ & 응 & 용 & 串 & 용 & $\stackrel{\circ}{\stackrel{0}{\circ}}$ & $\bar{\Xi}$ & $\frac{\sim}{\curvearrowright}$ & $\stackrel{m}{\frac{m}{\sigma}}$ & $\frac{ \pm}{\stackrel{\sim}{\sim}}$ & $\frac{n}{\stackrel{n}{(}}$ & $\frac{0}{0}$ & $\frac{\bar{D}}{\mathrm{\delta}}$ & $\frac{\infty}{\stackrel{\sim}{\sigma}}$ \\
\hline
\end{tabular}




\begin{tabular}{|c|c|c|c|c|c|c|c|c|c|c|c|c|c|c|c|c|}
\hline$\underbrace{\mathbb{L}}_{\bullet}$ & $\begin{array}{l}n \\
\frac{n}{6} \\
\frac{1}{2}\end{array}$ & \begin{tabular}{l}
$n$ \\
$\approx$ \\
\multirow{\sigma}{\sigma}{} \\
$\stackrel{\sim}{a}$
\end{tabular} & 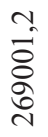 & $\begin{array}{l}n \\
\text { ñ } \\
\text { กิ } \\
\text { ôn }\end{array}$ & 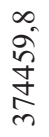 & 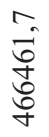 & $\begin{array}{l}\text { â } \\
\text { ๙ે } \\
\text { ळે }\end{array}$ & 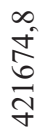 & 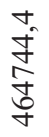 & 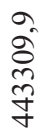 & 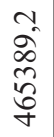 & $\begin{array}{l}\vec{a} \\
\vec{d} \\
\tilde{d} \\
\dot{\infty}\end{array}$ & 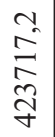 & \begin{tabular}{l}
$n$ \\
$\hat{\sigma}$ \\
$\hat{\sigma}$ \\
\multirow{\gamma}{*}{}
\end{tabular} & 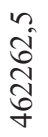 & $\begin{array}{l}\hat{\sigma} \\
\text { oे } \\
\text { oे } \\
\text { जे } \\
\text { n. }\end{array}$ \\
\hline $\begin{array}{l}\tilde{2} \\
0 \\
\dot{0}\end{array}$ & $\begin{array}{c}\nabla_{n} \\
\underset{f}{+}\end{array}$ & $\begin{array}{l}\hat{\sigma} \\
\frac{\hat{\sigma}}{+}\end{array}$ & $\frac{n}{6}$ & $\begin{array}{l}\tilde{\hat{V}} \\
\hat{\sigma}\end{array}$ & $\begin{array}{l}0 \\
\tilde{n} \\
\tilde{\infty}\end{array}$ & $\begin{array}{l}\stackrel{\nabla}{\infty} \\
\stackrel{\infty}{\Xi} \\
\Xi\end{array}$ & $\begin{array}{l}0 \\
\hat{b} \\
n \\
\sigma\end{array}$ & $\frac{\mathfrak{s}}{\stackrel{D}{a}}$ & 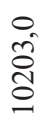 & $\begin{array}{l}\infty \\
\infty \\
\infty \\
\infty \\
\infty \\
0\end{array}$ & $\stackrel{\hat{\tilde{s}}}{\stackrel{0}{\Xi}}$ & $\begin{array}{l}\stackrel{\nabla}{ \pm} \\
\dot{\Xi} \\
\Xi\end{array}$ & 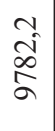 & $\begin{array}{l}\infty \\
\stackrel{\mathbb{N}}{\Omega} \\
\text {. }\end{array}$ & 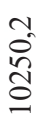 & $\begin{array}{l}\stackrel{a}{o} \\
\underline{\Xi}\end{array}$ \\
\hline 忌 & $\frac{\vec{n}}{\frac{n}{m}}$ & $\begin{array}{l}0 \\
0 \\
\delta \\
\varnothing \\
0 \\
n\end{array}$ & $\begin{array}{l}\stackrel{\hat{\vartheta}}{\Xi} \\
\vec{\gamma}\end{array}$ & $\begin{array}{l}m \\
\infty \\
\infty \\
\approx \\
\mathscr{\gamma}\end{array}$ & $\frac{O}{\underset{f}{f}}$ & $\begin{array}{l}\text { No } \\
\stackrel{8}{0} \\
\frac{n}{N}\end{array}$ & $\frac{\tilde{f}}{\text { fo }}$ & $\begin{array}{l}\text { ñ } \\
\text { ลิ } \\
\text { ֶิ }\end{array}$ & $\begin{array}{l}2 \\
\stackrel{\sigma}{\sigma}\end{array}$ & 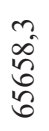 & $\begin{array}{l}n \\
n \\
o \\
o \\
0\end{array}$ & $\begin{array}{l}\stackrel{a}{\infty} \\
\stackrel{\infty}{\mathbb{N}}\end{array}$ & $\begin{array}{l}\infty \\
\infty \\
\infty \\
\hat{\sigma}\end{array}$ & $\begin{array}{l}a \\
\vec{b} \\
\vec{b}\end{array}$ & 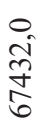 & $\begin{array}{l}\stackrel{a}{~} \\
\vec{n} \\
\frac{1}{7}\end{array}$ \\
\hline 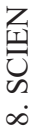 & $\begin{array}{l}n \\
\hat{O} \\
\stackrel{J}{d}\end{array}$ & 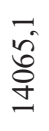 & 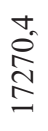 & $\begin{array}{l}n \\
\text { 응 } \\
\text { 。 }\end{array}$ & $\begin{array}{l}\vec{\sim} \\
\hat{n} \\
\hat{n}\end{array}$ & $\frac{\sigma_{n}}{\stackrel{m}{m}}$ & $\begin{array}{l}\infty \\
\infty \\
\infty \\
\infty \\
\infty \\
\sim\end{array}$ & 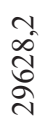 & 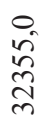 & 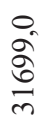 & $\begin{array}{l}\stackrel{0}{-} \\
\vec{J} \\
\dot{J} \\
m\end{array}$ & $\frac{\infty}{\stackrel{\infty}{\delta}}$ & $\frac{\vec{a}}{\vec{y}}$ & $\begin{array}{l}\hat{\partial े} \\
\stackrel{े}{ } \\
\text { ते }\end{array}$ & 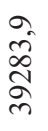 & 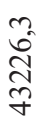 \\
\hline$\frac{\sqrt{2}}{\sim}$ & $\begin{array}{l}\text { n. } \\
0 \\
\delta \\
0 \\
\text { d }\end{array}$ & $\frac{\vec{a}}{\stackrel{n}{n}}$ & $\begin{array}{l}\overrightarrow{0} \\
\stackrel{0}{0} \\
\text { రీ }\end{array}$ & 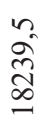 & $\begin{array}{l}n \\
\stackrel{N}{*} \\
\stackrel{\sim}{v}\end{array}$ & $\begin{array}{l}0 \\
\stackrel{0}{\circ} \\
\stackrel{0}{0}\end{array}$ & 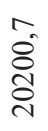 & 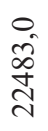 & 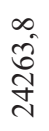 & 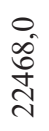 & $\begin{array}{l}\vec{A} \\
\vec{\infty} \\
\vec{\lambda}\end{array}$ & $\begin{array}{l}\overrightarrow{0} \\
\hat{0} \\
\tilde{n}\end{array}$ & 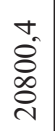 & $\begin{array}{l}\hat{\sigma} \\
\frac{\tilde{J}}{\sigma} \\
\vec{v}\end{array}$ & 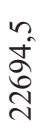 & 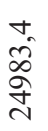 \\
\hline $\begin{array}{l}\text { Z } \\
\text { 品 } \\
\text {. }\end{array}$ & \begin{tabular}{l}
$m$ \\
$\infty$ \\
$\infty$ \\
\multirow{2}{*}{}
\end{tabular} & $\begin{array}{l}0 \\
\tilde{n} \\
\hat{\infty}\end{array}$ & $\stackrel{\hat{N}}{\hat{s}}$ & $\begin{array}{l}m \\
\stackrel{n}{\approx} \\
\stackrel{\Xi}{=}\end{array}$ & $\begin{array}{l}\stackrel{a}{\infty} \\
\underset{+}{0}\end{array}$ & $\begin{array}{l}\stackrel{0}{N} \\
\stackrel{N}{a} \\
\text { a }\end{array}$ & $\begin{array}{l}n \\
0 \\
0 \\
0 \\
n \\
n\end{array}$ & 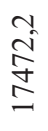 & $\begin{array}{l}\vec{n} \\
\tilde{n} \\
\text { o } \\
\end{array}$ & 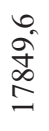 & $\begin{array}{l}\sim \\
\tilde{a} \\
\infty \\
\cong\end{array}$ & $\begin{array}{l}\hat{\sigma}^{2} \\
\infty \\
\infty \\
\vec{\sim}\end{array}$ & $\begin{array}{l}\overrightarrow{\mathrm{N}} \\
\overrightarrow{\mathbb{N}} \\
-\end{array}$ & $\begin{array}{c}0 \\
0 \\
⿱ 亠 \\
心 \\
\infty \\
-\end{array}$ & 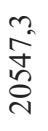 & 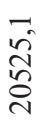 \\
\hline 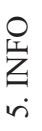 & $\begin{array}{l}0 \\
\vec{N} \\
\tilde{\infty}\end{array}$ & $\begin{array}{l}n \\
\tilde{\delta} \\
\tilde{\delta}\end{array}$ & $\begin{array}{l}n \\
\infty \\
\infty \\
\infty \\
=\end{array}$ & $\frac{\infty}{\infty}$ & $\begin{array}{l}\hat{\sigma} \\
\hat{0} \\
\hat{n}\end{array}$ & $\frac{n}{\hat{n}}$ & $\begin{array}{l}n \\
0 \\
0 \\
0 \\
-1\end{array}$ & $\begin{array}{l}\infty \\
\text { ô } \\
\text { fु }\end{array}$ & $\begin{array}{l}\hat{m} \\
\hat{b} \\
\stackrel{+}{I}\end{array}$ & $\begin{array}{l}\nabla_{0} \\
\tilde{b} \\
\infty \\
0\end{array}$ & $\begin{array}{l}\overrightarrow{0} \\
\tilde{\sigma} \\
\infty\end{array}$ & $\begin{array}{l}\infty \\
\vdots \\
\vdots \\
\vdots \\
\vdots\end{array}$ & $\begin{array}{l}n \\
\tilde{\delta} \\
\stackrel{1}{=} \\
\end{array}$ & 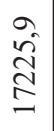 & $\begin{array}{l}\stackrel{a}{~} \\
\frac{\tilde{a}}{=}\end{array}$ & $\frac{\text { N }}{\stackrel{0}{8}}$ \\
\hline 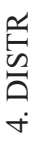 & $\begin{array}{l}\vec{\infty} \\
\infty \\
\stackrel{0}{\sigma} \\
\stackrel{\sigma}{\sigma}\end{array}$ & 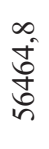 & $\begin{array}{l}n \\
\infty \\
\hat{N} \\
\infty \\
0\end{array}$ & $\begin{array}{l}\vec{a} \\
\stackrel{a}{5} \\
\frac{1}{2}\end{array}$ & $\begin{array}{l}n \\
\tilde{n} \\
\tilde{n} \\
\tilde{n}\end{array}$ & $\begin{array}{l}\infty \\
\stackrel{\infty}{\sigma} \\
ٍ\end{array}$ & 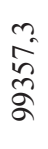 & 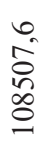 & $\begin{array}{l}\overrightarrow{0} \\
\stackrel{0}{0} \\
\Xi \\
=\end{array}$ & $\begin{array}{l}\underset{N}{N} \\
\stackrel{N}{N} \\
=\end{array}$ & 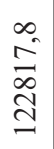 & 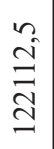 & 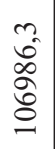 & $\begin{array}{l}\overrightarrow{0} \\
0 \\
\vdots \\
0\end{array}$ & $\begin{array}{l}\nabla^{\circ} \\
\hat{b} \\
\stackrel{\infty}{=}\end{array}$ & $\begin{array}{l}\stackrel{\sim}{~} \\
\stackrel{\sim}{\sim} \\
\stackrel{\sim}{ \pm}\end{array}$ \\
\hline 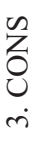 & $\begin{array}{l}n \\
\infty \\
\infty \\
\infty\end{array}$ & $\frac{\sqrt{\infty}}{\sqrt{0}}$ & $\hat{\tilde{N}}$ & $\underset{\vec{j}}{\stackrel{\vec{j}}{\vec{d}}}$ & 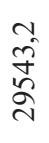 & $\begin{array}{l}n \\
n \\
n \\
\infty \\
\infty\end{array}$ & $\begin{array}{l}\infty \\
\stackrel{+}{+} \\
\underset{m}{+}\end{array}$ & $\begin{array}{l}\hat{8} \\
8 \\
\infty \\
\infty\end{array}$ & $\begin{array}{l}0 \\
i \\
\infty \\
\tilde{+} \\
\tilde{f}\end{array}$ & $\begin{array}{l}\hat{n} \\
\text { ñ } \\
\text { ñ }\end{array}$ & $\begin{array}{l}n \\
\tilde{n} \\
\tilde{y} \\
\tilde{n}\end{array}$ & 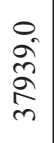 & $\begin{array}{l}\vec{a} \\
\vec{\infty} \\
\vec{n}\end{array}$ & 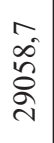 & $\begin{array}{l}\stackrel{g}{0} \\
\underset{d}{d}\end{array}$ & $\begin{array}{l}\infty \\
\stackrel{0}{\circ} \\
\stackrel{0}{0} \\
\stackrel{y}{\sigma}\end{array}$ \\
\hline $\begin{array}{l}\stackrel{\mathfrak{Z}}{\text { Z }} \\
\stackrel{\sim}{\sim}\end{array}$ & 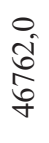 & $\begin{array}{l}0 \\
\infty \\
\infty \\
i n\end{array}$ & $\frac{\infty}{\infty}$ & 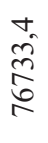 & $\frac{a}{\hat{n}}$ & 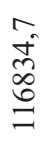 & $\begin{array}{l}\nabla_{0} \\
\hat{n} \\
\frac{n}{a}\end{array}$ & 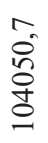 & $\begin{array}{l}\vec{\Xi} \\
\underline{\Xi}\end{array}$ & 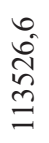 & 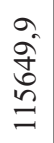 & 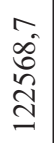 & $\begin{array}{l}\stackrel{a}{e} \\
\stackrel{8}{o} \\
\varrho \\
=\end{array}$ & $\begin{array}{l}\vec{\infty} \\
\vec{n} \\
\hat{\sigma}\end{array}$ & 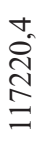 & $\underset{\stackrel{\infty}{\Xi}}{\stackrel{\infty}{\Xi}}$ \\
\hline 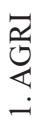 & 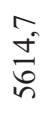 & $\underset{\infty}{\stackrel{0}{\infty}}$ & $\underset{\infty}{\stackrel{n}{\infty}}$ & $\begin{array}{l}\text { तิ } \\
\text { ते } \\
\text { a }\end{array}$ & \begin{tabular}{l}
\multirow{2}{0}{} \\
$\stackrel{\partial}{ }$ \\
\end{tabular} & $\begin{array}{l}0 \\
\hat{n} \\
\stackrel{n}{n} \\
m\end{array}$ & 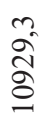 & $\begin{array}{l}\stackrel{\text { oे }}{\infty} \\
\stackrel{\text { }}{\text { I }}\end{array}$ & $\begin{array}{l}\infty \\
\stackrel{n}{a} \\
\stackrel{a}{I}\end{array}$ & $\underset{m}{\stackrel{0}{m}}$ & $\begin{array}{l}0 \\
\stackrel{0}{0} \\
\stackrel{0}{0} \\
n\end{array}$ & $\begin{array}{l}\infty \\
\stackrel{\sim}{J} \\
\stackrel{J}{J}\end{array}$ & $\frac{m}{\stackrel{m}{\sigma}}$ & $\begin{array}{c}\hat{\hat{n}} \\
\stackrel{\Xi}{=}\end{array}$ & $\begin{array}{l}\vec{\Omega} \\
\text { J } \\
\stackrel{J}{J}\end{array}$ & 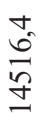 \\
\hline$\stackrel{\Xi}{\tilde{Z}}$ & ڤి & ষ্ণ & 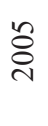 & $\begin{array}{l}\text { ¿̊ } \\
\text { ¿ }\end{array}$ & 홍 & $\stackrel{\infty}{\stackrel{\infty}{\circ}}$ & \&े & $\stackrel{\circ}{\stackrel{ }{\circ}}$ & ন্ & $\frac{\sim}{\stackrel{i}{d}}$ & $\stackrel{m}{\stackrel{\sim}{\sim}}$ & $\stackrel{\vec{d}}{\vec{d}}$ & $\frac{n}{\stackrel{i}{c}}$ & $\stackrel{0}{\circ}$ & $\stackrel{ }{\stackrel{\sim}{d}}$ & $\stackrel{\infty}{\stackrel{\infty}{\sigma}}$ \\
\hline
\end{tabular}




\begin{tabular}{|c|c|c|c|c|c|c|c|c|c|c|c|c|c|c|c|c|}
\hline$\stackrel{I}{\ominus}$ & $\begin{array}{l}\overrightarrow{8} \\
8 \\
0 \\
0\end{array}$ & $\begin{array}{c}m \\
\stackrel{0}{0} \\
\stackrel{0}{n}\end{array}$ & $\begin{array}{l}0 \\
\hat{n} \\
\text { ô } \\
\text { a }\end{array}$ & $\begin{array}{l}\stackrel{\vartheta}{~} \\
\text { ô } \\
\stackrel{n}{J}\end{array}$ & $\begin{array}{l}a \\
n \\
n \\
n\end{array}$ & $\frac{a}{i}$ & $\begin{array}{l}\stackrel{+}{a} \\
\infty \\
\stackrel{2}{n}\end{array}$ & 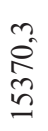 & $\begin{array}{l}n \\
n \\
n \\
n\end{array}$ & 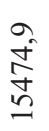 & $\begin{array}{l}\infty \\
\text { ஸे } \\
\stackrel{n}{n}\end{array}$ & $\frac{0}{\stackrel{n}{n}}$ & $\begin{array}{l}\stackrel{0}{0} \\
\text { مू } \\
\text { ㅇ }\end{array}$ & ڤ్̊ి & $\begin{array}{l}0 \\
\stackrel{n}{n} \\
\underline{\sigma}\end{array}$ & $\begin{array}{l}\vec{a} \\
\text { ర్రి } \\
\text { - }\end{array}$ \\
\hline $\begin{array}{l}\mathscr{2} \\
0 \\
\dot{0}\end{array}$ & 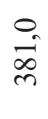 & $\underset{⿱}{\stackrel{N}{n}}$ & $\frac{n}{n}$ & $\stackrel{\hat{\infty}}{\stackrel{\sim}{f}}$ & $\begin{array}{l}\stackrel{\sim}{f} \\
\stackrel{f}{f}\end{array}$ & $\begin{array}{l}0 \\
\stackrel{f}{f}\end{array}$ & 苘 & $\begin{array}{l}\dot{\sigma}_{0} \\
\dot{\theta} \\
\dot{f}\end{array}$ & $\begin{array}{l}\hat{\sigma} \\
\text { fo }\end{array}$ & $\begin{array}{l}0 \\
\tilde{\sigma} \\
\tilde{\sigma}\end{array}$ & $\begin{array}{l}\nabla_{0} \\
\dot{b} \\
\dot{f}\end{array}$ & $\stackrel{n}{\sim}$ & $\begin{array}{l}\infty \\
\stackrel{\infty}{\infty} \\
\underset{f}{+}\end{array}$ & $\begin{array}{l}\text { N } \\
\infty \\
\infty \\
+\end{array}$ & $\begin{array}{l}0 \\
\text { î } \\
\text { in }\end{array}$ & $\begin{array}{l}n \\
8 \\
8\end{array}$ \\
\hline 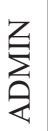 & $\begin{array}{l}\stackrel{\sigma}{े} \\
\underset{\sim}{\infty}\end{array}$ & 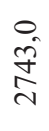 & $\frac{\nabla_{n}}{\stackrel{\infty}{\sim}}$ & $\begin{array}{l}\hat{\sigma} \\
\text { } \\
\text { ते }\end{array}$ & $\begin{array}{l}\stackrel{n}{\widehat{N}} \\
\text { }\end{array}$ & $\begin{array}{l}0 \\
\infty \\
\infty \\
\infty\end{array}$ & $\frac{n}{n}$ & $\stackrel{m}{\stackrel{m}{=}}$ & $\begin{array}{l}\text { Oे } \\
\dot{0} \\
\infty \\
\infty\end{array}$ & $\frac{\hat{\sigma}}{\stackrel{i}{m}}$ & ભે & $\underset{\sim}{\stackrel{\sim}{\sim}}$ & $\begin{array}{l}0 \\
\overrightarrow{0} \\
\sim \\
\sim\end{array}$ & $\begin{array}{l}\text { in } \\
\stackrel{n}{n} \\
\text { ñ }\end{array}$ & $\begin{array}{l}\text { N } \\
\tilde{e} \\
\tilde{n}\end{array}$ & $\underset{\hat{m}}{\stackrel{\vec{m}}{2}}$ \\
\hline $\begin{array}{l}Z \\
\text { Z } \\
\text { 己 } \\
\infty \\
\infty \\
\infty\end{array}$ & $\frac{n}{n}$ & $\begin{array}{l}0 \\
0 \\
0 \\
0\end{array}$ & $\begin{array}{l}\hat{o} \\
\text { fo }\end{array}$ & 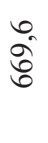 & $\begin{array}{l}\infty \\
\hat{n} \\
n\end{array}$ & $\begin{array}{l}0 \\
\stackrel{2}{N} \\
\text { N }\end{array}$ & $\begin{array}{l}\text { m. } \\
\stackrel{+}{\infty}\end{array}$ & $\underset{\infty}{\stackrel{0}{\infty}}$ & $\frac{\hat{\sigma}}{a}$ & $\begin{array}{l}\hat{\infty} \\
\approx \\
\approx\end{array}$ & $\begin{array}{l}\tilde{o} \\
\dot{q}\end{array}$ & $\begin{array}{l}\stackrel{?}{0} \\
0\end{array}$ & 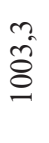 & $\begin{array}{l}\hat{\infty} \\
\text { ஸे } \\
\hat{0}\end{array}$ & $\begin{array}{l}\nabla_{0} \\
\stackrel{\infty}{0}\end{array}$ & $\begin{array}{l}\infty \\
\hat{\sigma}^{\circ} \\
\stackrel{0}{0}\end{array}$ \\
\hline$\frac{\sqrt{2}}{2}$ & 寺 & 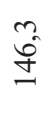 & 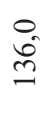 & $\vec{\Xi}$ & $\begin{array}{l}\infty \\
\infty \\
\stackrel{0}{\beth}\end{array}$ & $\begin{array}{l}\infty \\
\stackrel{I}{ \pm}\end{array}$ & 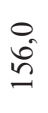 & $\tilde{\sigma}$ & $\begin{array}{l}\text { r } \\
\text { đo }\end{array}$ & $\begin{array}{l}\infty \\
0 \\
\text { I }\end{array}$ & $\begin{array}{l}\infty \\
\stackrel{\sim}{ \pm}\end{array}$ & $\stackrel{n}{8}$ & $\stackrel{n}{\stackrel{n}{\Xi}}$ & $\begin{array}{l}+ \\
\text { î } \\
-\end{array}$ & $\begin{array}{l}0 \\
\text { on } \\
\text { I }\end{array}$ & $\hat{\tilde{n}}$ \\
\hline $\begin{array}{l}\underset{I}{Z} \\
\stackrel{0}{0}\end{array}$ & $\begin{array}{l}\hat{n} \\
\hat{n}\end{array}$ & 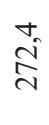 & & $\begin{array}{l}\hat{\infty} \\
\hat{\infty}\end{array}$ & ஸే & $\stackrel{n}{\vec{f}}$ & 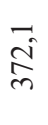 & $\hat{i}$ & $\underset{m}{\stackrel{0}{\infty}}$ & $\begin{array}{l}0 \\
\text { à } \\
\text { ले }\end{array}$ & $\vec{m}$ & $\begin{array}{c}\stackrel{+}{\infty} \\
\stackrel{\infty}{\infty}\end{array}$ & $\begin{array}{l}n \\
\text { ڤे } \\
\text { mे }\end{array}$ & $\begin{array}{l}n \\
\stackrel{0}{\infty} \\
\infty \\
n\end{array}$ & $\begin{array}{l}\nabla_{0} \\
\stackrel{m}{ }\end{array}$ & $\begin{array}{l}\overrightarrow{0} \\
\vec{\gamma}\end{array}$ \\
\hline $\begin{array}{l}\text { O } \\
\text { 贡 } \\
\text { in } \\
\text { in }\end{array}$ & $\vec{\sigma}$ & $\frac{a}{\vec{v}}$ & $\begin{array}{l}\hat{n} \\
\vec{v}\end{array}$ & กิ & $\begin{array}{l}n \\
\infty \\
\infty \\
\sim\end{array}$ & $\begin{array}{l}\hat{\diamond} \\
\stackrel{2}{ }\end{array}$ & $\frac{\vec{\sigma}}{m}$ & बे & $\begin{array}{l}\text { बे } \\
\stackrel{2}{~}\end{array}$ & $\frac{\vec{\sigma}_{n}}{\stackrel{n}{n}}$ & $\begin{array}{l}\infty \\
\text { ñ } \\
\text { ñ }\end{array}$ & $\overrightarrow{8}$ & $\begin{array}{l}0 \\
\underset{n}{n}\end{array}$ & 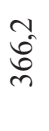 & $\begin{array}{c}\hat{n} \\
\ddot{n}\end{array}$ & $\stackrel{n}{\tilde{\sigma}}$ \\
\hline 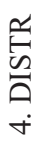 & $\begin{array}{l}n \\
\tilde{D} \\
\infty \\
\sim\end{array}$ & 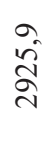 & $\begin{array}{l}\text { ñ } \\
\text { } \\
\stackrel{2}{\alpha}\end{array}$ & $\overrightarrow{\stackrel{m}{n}}$ & $\vec{i}$ & $\begin{array}{l}0 \\
\stackrel{n}{n} \\
m\end{array}$ & $\begin{array}{l}\hat{b} \\
\hat{n} \\
n\end{array}$ & $\underset{m}{\stackrel{m}{+}}$ & 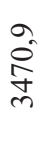 & $\begin{array}{l}\stackrel{\circ}{2} \\
\stackrel{2}{+}\end{array}$ & $\begin{array}{l}\hat{0} \\
\dot{0} \\
\dot{m}\end{array}$ & 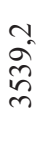 & $\begin{array}{l}\text { N } \\
\infty \\
0 \\
0 \\
0\end{array}$ & $\begin{array}{l}\infty \\
\hat{\sigma} \\
\hat{\sigma}\end{array}$ & $\underset{m}{\stackrel{n}{m}}$ & $\begin{array}{l}n \\
\frac{n}{n}\end{array}$ \\
\hline 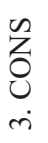 & $\begin{array}{l}\text { ڤे } \\
\text { ळे }\end{array}$ & $\stackrel{\nabla_{n}}{\stackrel{2}{2}}$ & $\stackrel{\partial}{\hat{\infty}}$ & $\begin{array}{l}\infty \\
\stackrel{+}{\sigma}\end{array}$ & $\begin{array}{l}\stackrel{0}{0} \\
\text { İ }\end{array}$ & 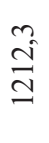 & $\begin{array}{l}\infty \\
\stackrel{0}{0} \\
\stackrel{\infty}{\triangle}\end{array}$ & $\begin{array}{l}\hat{\overbrace{}} \\
\text { తి }\end{array}$ & $\begin{array}{l}+ \\
\text { o̊ } \\
\stackrel{\text { Id }}{ }\end{array}$ & $\stackrel{\text { I }}{\Xi}$ & $\begin{array}{l}\exists \\
\exists \\
\Xi\end{array}$ & $\begin{array}{l}\stackrel{\sim}{ \pm} \\
\stackrel{m}{=}\end{array}$ & 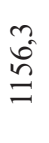 & $\begin{array}{l}\infty \\
\stackrel{\infty}{\Xi} \\
=\end{array}$ & $\begin{array}{l}0 \\
\hat{0} \\
\underline{=}\end{array}$ & 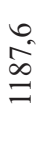 \\
\hline $\begin{array}{l}\stackrel{?}{2} \\
\underset{Z}{\sim} \\
\dot{\sim}\end{array}$ & $\begin{array}{l}n \\
\hat{\alpha} \\
\hat{\rho}\end{array}$ & $\begin{array}{l}n \\
\text { है } \\
\text { nn }\end{array}$ & $\frac{\infty}{m}$ & 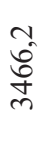 & $\begin{array}{l}\text { N } \\
\text { है } \\
\text { n }\end{array}$ & $\begin{array}{l}\infty \\
\dot{D} \\
\infty \\
\infty\end{array}$ & 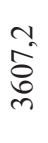 & $\begin{array}{l}\infty \\
\text { ô } \\
\text { dे }\end{array}$ & $\begin{array}{l}\hat{\sigma} \\
\infty \\
\stackrel{m}{m}\end{array}$ & $\begin{array}{l}\infty \\
\dot{f} \\
\stackrel{5}{m}\end{array}$ & 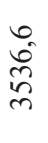 & $\begin{array}{l}\infty \\
\text { त్ } \\
\text { }\end{array}$ & 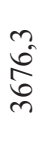 & 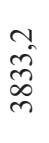 & $\begin{array}{l}\infty \\
\hat{0} \\
\\
\text { mे }\end{array}$ & 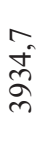 \\
\hline 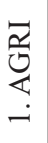 & $\begin{array}{l}0 \\
\tilde{n} \\
\tilde{n} \\
\end{array}$ & $\begin{array}{l}n \\
\text { oे } \\
\stackrel{+}{\sim}\end{array}$ & 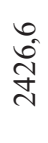 & 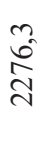 & $\begin{array}{l}0 \\
\infty \\
\stackrel{\infty}{d}\end{array}$ & $\begin{array}{l}+ \\
\stackrel{\sigma}{\sigma} \\
\stackrel{\sim}{v}\end{array}$ & $\begin{array}{l}\stackrel{+}{~} \\
\stackrel{\sim}{\partial}\end{array}$ & ๙ి & $\begin{array}{l}\text { If } \\
\text { gे }\end{array}$ & $\begin{array}{l}a े \\
\text { İ } \\
=\end{array}$ & $\begin{array}{l}\hat{\tilde{n}} \\
\tilde{\infty}\end{array}$ & 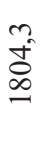 & $\stackrel{\vec{\Phi}}{\vec{D}}$ & $\frac{0}{i}$ & $\begin{array}{l}\hat{a} \\
\tilde{\sigma}\end{array}$ & $\begin{array}{l}\infty \\
\stackrel{n}{n} \\
n\end{array}$ \\
\hline$\underset{\nabla}{\grave{\Xi}}$ & ڤి̊ & ষ্ণ & 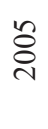 & ஜ̊ & ¿্ণ & $\stackrel{\infty}{\stackrel{0}{े}}$ & ஓे & $\stackrel{\circ}{\stackrel{\sim}{\sim}}$ & $\overrightarrow{\vec{\sim}}$ & $\frac{\sim}{\stackrel{\sim}{\sim}}$ & $\frac{m}{\stackrel{d}{d}}$ & $\underset{\sim}{\stackrel{D}{\sigma}}$ & $\frac{n}{\stackrel{d}{d}}$ & $\stackrel{0}{\stackrel{0}{0}}$ & $\stackrel{\bar{c}}{\bar{d}}$ & $\stackrel{\infty}{\underset{\sim}{\sigma}}$ \\
\hline
\end{tabular}


